\title{
A synoptic revision of Inversodicraea (Podostemaceae)
}

\author{
M. Cheek ${ }^{1}$, A. Feika ${ }^{2}$, A. Lebbie ${ }^{2}$, D. Goyder ${ }^{1}$, B. Tchiengue ${ }^{3}$, O. Sene $^{3}$, \\ P. Tchouto ${ }^{4}, X$. van der Burgt ${ }^{1}$
}

\section{Key words}

conservation extinction risk hybridisation

hydroelectric dam projects rheophytes

stage-dependent heteromorphy

\begin{abstract}
Six new species of Inversodicraea (I. feika from Sierra Leone, I. liberia from Liberia, and I. ebo, I. eladii, I. tchoutoi, and $I$. xanderi from Cameroon) are described as new to science in the context of a synoptic revision of this African genus, now comprising 30 species, including $I$. cussetiana comb. nov., newly transferred from Macropodiella. Inversodicraea is now equal in number of species to Ledermanniella (as redefined), as the largest genus of the family in Africa. Terete or slightly dorsiventrally flattened leaf petioles (not sheathing and/or stipulate) are newly discovered to distinguish the genus from Ledermanniella, in addition to the presence of scale-leaves. Inversodicraea boumiensis, I. annithomae, and I. bosii are redelimited in this paper. Examples of species hybrids are discussed. Eighteen species are point endemics. A key and IUCN 2012 standard conservation assessments for all species are included. 28 of the 30 species have been assessed as Threatened or Near Threatened. Hydroelectric projects are the biggest source of extinction risk to species of the genus, threatening 19 of the 30 species.
\end{abstract}

Published on 13 September 2017

\section{INTRODUCTION}

Podostemaceae are a pantropical family of annual or perennial herbs placed in Malpighiales in a sister relationship with Hypericaceae. There are about 300 species globally, in c. 54 genera (Koi et al. 2012, Kato 2016). Species numbers are highest in tropical America, followed by Asia, with Africa having c. 80 species. All species of the family are restricted to rocks in rapids and waterfalls of clear-water rivers, and are therefore rheophytes (torrenticolous). However, this very habitat is being increasingly exploited for hydropower at some risk to the survival of the Podostemaceae they contain (Schenk et al. 2015, Cheek et al. 2015, Cheek \& Ameka 2016). Most of the African species of Podostemaceae are narrow endemics, many being species known from only a single waterfall. New discoveries of species are still being made frequently (Rial 2002, Cheek 2003, Schenk \& Thomas 2004, Beentje 2005, Kita et al. 2008, Schenk et al. 2015, Cheek et al. 2015, Cheek \& Ameka 2016, Cheek \& Haba 2016a). Important characters in defining African genera in Podostemaceae are the position of the flower in the unruptured spathellum, and the shape and sculpture of the ovary. At species level, important characters are the shape and relative proportions of spathellae, stigmas, anthers, filaments, gynophores, pedicels, and leaves.

The current generic classification of African Podostemaceae is based on the framework established by Cusset (1973, 1974, $1978,1983,1984,1987,1997)$. This work has been compiled and updated by Rutishauser et al. (2004) who recognise c. 85 species in 16 genera. Recently, combined morphological and molecular phylogenetic studies of African Podostemaceae have shown that Ledermanniella (as delimited by Cusset) is paraphyletic, including all other sampled genera of Podostemaceae

\footnotetext{
1 Science, Royal Botanic Gardens, Kew, Richmond, Surrey, TW9 3AE, United Kingdom; corresponding author e-mail: m.cheek@kew.org.

2 National Herbarium, University of Sierra Leone, Njala, Private Mail Bag, Sierra Leone.

3 IRAD-Herbier National du Cameroun, Yaoundé, BP 1601, Cameroun.

${ }^{4}$ Programme for the Sustainable Management of Natural Resources, Buea, P.O. Box 417, South West Region, Cameroon.
}

recognised in Africa (Thiv et al. 2009, employing plastid markers matK, trnD-trnT, rpoB-trnC in sampling 9 genera and 17 species of African Podostemaceae, and Schenk et al. (2015), employing plastid markers matK, trnL, rpoB-trnC, $n d h \mathrm{~F}, r b c \mathrm{~L}$ and matR in sampling 10 genera and 27 species of African Podostemaceae). Molecular phylogenetic sampling of African Podostemaceae has been only c. $30 \%$ complete at species level (Schenk et al. 2015). Thiv et al. (2009) and Schenk et al. (2015), have convincingly shown that Ledermanniella subg. Phyllosoma C.Cusset forms a well-supported clade of species that are sister to the rest of all other African Podostemaceae sampled, comprising Ledermanniella subg. Ledermanniella and, embedded within it, 9 smaller genera: Macropodiella, Winklerella, Djinga, Monandriella, Dicraeanthus, Leiothylax, Letestuella, and Stonesia. Thiv et al. (2009) and Schenk et al. (2015) both advocate resurrecting the generic name Inversodicraea Engl., as the oldest generic name for the species of Ledermanniella subg. Phyllosoma and both transfer species formerly included under the last taxon to Inversodicraea. The last 7 remaining species names of subg. Phyllosoma for which formal transfer was necessary were placed into Inversodicraea in Cheek \& Haba (2016a).

Thus Inversodicraea has been resurrected to accommodate those species previously included in Ledermanniella subg. Phyllosoma (Thiv et al. 2009, Schenk et al. 2015, Cheek \& Haba 2016a). Material has come to light representing new species which are published here together with a synoptic account and a key to all the species currently recognised.

\section{MATERIALS \& METHODS}

Nomenclatural changes and lectotypifications were made according to the Code (McNeil et al. 2012). Names of species and authors follow IPNI (continuously updated). Herbarium material was examined with a Leica Wild M8 dissecting binocular microscope fitted with an eyepiece graticule measuring in units of $0.025 \mathrm{~mm}$ at maximum magnification. The drawings (Fig. 2-8) were made with the same equipment with a Leica 308700 camera lucida attachment. Pollen grains were exam- 
ined from macerated single stamens mounted in a water drop on a slide with coverslip and examined with a compound light microscope using a $\times 40$ objective lens fitted with a calibrated eyepiece graticule for measurements.

Species are recognised on the basis of being separated from all other species of the genus by three or more disjunct morphological characters, ideally qualitative, and with no intermediate specimens being present. These characters are presented in the key to the species, and in the cases of new species described in this paper, in tables of characters and in the species diagnosis, being further discussed in the notes. In four species at two sites intermediate specimens have been found which we ascribe to hybridisation.

The arrangement of species in the taxonomic treatment follows that of Cusset (1983), with modifications. All specimens known are cited except for the most common and widespread species I. ledermannii and I. tenax, where only representative specimens are cited for each country in which that species occurs. Specimens were inspected from the following herbaria: BM, $\mathrm{FHO}, \mathrm{HNG}, \mathrm{K}, \mathrm{P}, \mathrm{WAG}$, and YA. BR and COI specimens were not accessible since they were being digitised during the period of study. Where altitudes at which specimens were collected were not recorded on specimen labels, specimen sites were traced using Google Earth and altitudes read from that source.

Field observations and collections of Inversodicraea were made by the authors in West and Central Africa in the period 1995-2016, in Guinea, Sierra Leone, and Cameroon.

The format of the description follows Cusset (1983), e.g., in referring to the specialized ribbon-like roots as 'thallus', and long, subfiliform, to narrowly ribbon-like dichotomously branched leaves as 'leaves'. However, we do not refer to the scaleleaves as 'leaflets' ('feuillettes') since, as an anonymous reviewer has pointed out, a leaflet is technically one element of a compound leaf, and this is not the case with these structures. All specimens marked have been seen except those marked 'n.v.'. The conservation assessment follows the IUCN (2012) standard, using the IUCN-preferred grid cell size of $1 \mathrm{~km}^{2}$ for riverine organisms unless noted otherwise. The main online search address used for retrieving specimen data from labels at $\mathrm{P}$ was https://science.mnhn.fr/institution/mnhn/collection/p/item/ p00179355? listIndex $=128 \&$ listCount $=610$. However, resolution of images of herbarium specimens was insufficient in all cases to confirm specimen identification. Herbarium codes follow Index Herbariorum (Thiers, continuously updated).

\section{MORPHOLOGY}

The morphology and anatomy of three species of Inversodicraea, I. ledermannii, I. cf. bosii, and I. cristata, have been presented in detail by Moline et al. (2007) and Thiv et al. (2009). This information was part of their wider study of about ten species of African Podostemoideae. Here we give an overview of the different structures found in the genus Inversodicraea, and their range in variation across the 30 currently known species of the genus. The overview is based on morphological observations made when researching this paper, combined with data from Cusset (1983) and the excellent in-depth studies of the three species reported by Moline et al. (2007) and Thiv et al. (2009).

\section{Root}

The root (Thiv et al. 2009), also known as the thallus (Cusset 1983), is narrowly ribbon-like, that is dorsiventrally compressed, usually about three times wider than thick, and adheres to the substrate by numerous short adhesive hairs (root hairs or rhizoids) that depend from the lower (ventral) surface, except- ing from the midline (see Moline et al. 2007: f. 2B). A single dorsiventrally flattened vascular bundle is present. A rootcap is lacking (Moline et al. (2007) and Thiv et al. (2009)). Disc-like hold fasts are produced where leaves arise from the margin of the root (I. ledermannii: Moline et al. 2007: f. 2C).

The root (thallus) is described by Cusset (1983) as $1 \mathrm{~mm}$ wide in almost every species, except in I. ledermannii $(2-3 \mathrm{~mm})$, I. mortonii $(0.5 \mathrm{~mm})$, I. warmingiana (1-1.5 mm), I. feika (0.6-1 $\mathrm{mm}$, this paper). The root is not recorded in the following species: I. boumiensis, I. digitata, I. harrisii, I. abbayesii, I. bosii, I. kamerunensis, I. torrei, and I. pepehabai. Thalli are often not collected because they can be so difficult to remove intact from the rock substrate in contrast to the remainder of the plant (Cheek pers. obs). Foliaceous thalli (implying that they are much broader) are recorded for I. gabonensis and I. thollonii but their width is not given (Cusset 1983).

Branching of the root-thallus occurs endogenously (arising from the interior, not budding off from the exterior) where it has been recorded (Moline et al. (2007) and Thiv et al. (2009)). This has been confirmed in I. achoundongii (Schenk et al. 2015: 542), and we have observed this also, e.g., in I. feika (Fig. 2, 3), I. xanderi (Fig. 5).

\section{Stems}

Stems subtended by leaves, arise from both margins of the root, either alternating (I. ledermannii, Moline et al. 2007: f. 2C) or opposite to each other as in I. feika (Fig. 2) and I. achoundongii (Schenk et al. 2015), but for most species these data are either not preserved or not recorded.

Stems also arise endogenously where recorded (I. feika, Fig. 2 and $I$. achoundongii Schenk et al. 2015).

Stems can be either erect, self-supporting and short-lived (annual), when usually only $2-5 \mathrm{~cm}$ tall (e.g., I. ledermannii) or erect, self-supporting, and seemingly long-lived (apparently growing for more than one season, e.g., in I. ebo, I. cristata, 1. tchoutoi), or with an elongate principle stem of $20-80 \mathrm{~cm}$ or more (80 $\mathrm{cm}$ in $I$. feika and $I$. warmingiana), which flows in the current, carries few scale-leaves, or none (e.g., I. annithomae, I. paulsitae), but which bears either long lateral branches bearing leaves only and/or shorter spur-branches bearing flowers (e.g., I. adamesii) or is unbranched apart from the short, regular, densely leaflet-clad spur-branches (e.g., I. annithomae, I. paulsitae).

Pseudo-dichotomous stem branching is conspicuous in some species, such as I. cristata, I. ebo, I. tchoutoi, I. ntemensis, presumably due to these species having determinate stems which terminate in a flower or a leaf, the stems continuing to grow through new shoots that can arise on both sides so that the stems appear to fork dichotomously with the leaf or flower in the fork of the dichotomy. Should a new shoot develop on one side only, the leaves and flowers will appear lateral. This is explained by 'double-sheathing leaves' (Moline et al. (2007) and Thiv et al. (2009)). These references should be consulted for a detailed explanation of this remarkable phenomenon.

\section{Leaf phyllotaxy}

The leaf phyllotaxy on stems appears spiral, rarely distichous (I. annithomae, I. paulsitae), never opposite. In some species the leaves appear in the axils of stem pseudo-dichotomies (see I. tchoutoi Fig. 5b), as a result of the 'double-sheathed stems' referred to above. The leaves are elongate and (pseudo-) dichotomously branched, the ultimate segments terete or flattened (ribbon-like). They contain vascular bundles that extend to the ultimate segments (Thiv et al. 2009). The petiole is terete. Sheathing leaf bases and stipules have never been recorded in Inversodicraea as delimited in this paper except in I. kamer- 
unensis fide Cusset (1983: 386). However, since this species is known from the single specimen Ledermann $440 A$, that we believe was not seen by Cusset, this statement is likely to be an error since we were unable to detect these features in the specimen ourselves. Despite searching for these features in every species of the genus included in this paper, we have not been able to detect them and conclude that they do not occur. Thiv et al. (2009), also state that they had not observed these features in Inversodicraea although they could not be sure of their absence due to the leaflets that interfere with observation of leaf bases in many species.

Leaves are probably the main photosynthetic and also the main absorbitive structures since they have a large surface relative to their volume and a thin cuticle (in contrast the root hairs or rhizoids which have a much lower surface area and primarily seem to function as anchoring structures). The leaves are only present when the plants are under water or continually sprayed by water droplets from a waterfall. Once plants are exposed by falling water levels in the dry season, the leaves fall rapidly, usually before the flowers open. We postulate that since the leaves have very thin cuticle, this leaf-drop mechanism reduces the loss of water from the plant as a whole that might otherwise compromise seed production, and in long-lived species, their perenniality. An abscission zone has not been observed. Since plants are usually collected only when in flower, the leaves are often not collected. For those several species where leaves have not been recorded, it is not known whether it is because they are not produced (as claimed of I. boumiensis by Schenk et al. 2015) or simply because they have not been collected before the leaves have fallen.

\section{Scale-leaves}

Scale-leaves ('feuillettes', meaning leaflets, of Cusset 1983) are present in all species. They lack vascular bundles (Thiv et al. 2009). Insertion is spiral, rarely in loose whorls of three (e.g., I. adamesii (Taylor 1953: f. 9/2) and I. ntemensis (Kita et al. 2008: f. 1)), never opposite. Files of scale-leaves (i.e. scaleleaves appearing to be in longitudinal lines down the stem) can be observed in some species with spirally inserted leaves, such as $I$. eladii (c. 5 leaf files) and less usually, with only c. 3 files, I. liberia.

The scale-leaves of Inversodicraea appear to be a unique synapomorphy, certainly within African Podostemoideae. However, in Tristicha (Tristichoideae, sister to all other Podostemaceae) scale-leaves are also developed. The leaflet-clad stems of I. liberia, being tristichous, resemble those of Tristicha. Perhaps expression of scale-leaves in Inversodicraea arose from 'switching-on' genes that had long lain dormant in the Podostemoideae genome. However, it is not known that the scaleleaves of Inversodicraea are homologous with those of Tristicha. Katayama et al. (2010) have shown that shoot apical meristems (SAMs) while present in Tristichoideae are lacking in Podostemoideae, and that organogenesis is therefore different.

Scale-leaves either:

1. completely cover the entire stem(s) as in I. ledermannii;

2. cover completely the distal $50-80 \%$ of the stems (e.g., I. ebo);

3. cover densely only the spur shoots bearing the flowers, and then are absent or are only very sparsely covering the principal axes (e.g., I. paulsitae); or

4. are not present immediately below the flowers but are scattered along the main axis ( $I$. achoundongii, Schenk et al. 2015).

The precise shape, and especially the marginal ornamentation of the scale-leaves, is the single most important source of characters for species delimitation in Inversodicraea. The overall shape varies from needle-like (I. mortonii) to orbicular (I. boumiensis), through equilaterally triangular, ovate, and oblong. While the first mentioned species have entire margins, some have one or two irregular lateral lobes (e.g., I. pepehabai) or an erose, erratically minutely lobed margin (I. kamerunensis). More usually, the margins are regularly toothed, the shape, depth, and number of teeth being characteristic of the species.

The scale-leaves are always either flat, concave, or acicular. Rarely do they bear projections from their abaxial surface (I. harrisii, I. xanderi, I tenax, and I. congolana).

While in some species the scale-leaves are monomorphic, in others they are more or less dimorphic, as in I. cristata, I. tchoutoi, I. xanderi. In these cases the scale-leaves on the branches differ from those on the main stems (I. cristata, I. tchoutoi), or those subtending the spathellae differ from those on the stems below (e.g., I. xanderi). This equates to stage-dependent heteromorphy. In these cases, generally speaking, scale-leaves subtending the spathellae are more slender and have fewer lobes than those on the main body of the stems below.

Scale-leaves appear to function as armature in most Inversodicraea. The scale-leaves, especially the epidermal cells, are filled with silica bodies, unlike the leaves (Thiv et al. 2009). These silica bodies are uniform between species, being more or less isodiametric, apart from the outer face which is convex and has a median line of pits. Thiv et al. (2009) speculated that the silica bodies protect the plants against bombardment from current-borne pebbles and other projectiles. Yet, we consider it as or more likely that they have a probably more important function: protection against herbivores. Just as silica bodies in grasses help to protect them from grazing animals, we postulate that so do the silica bodies in the epidermis of Inversodicraea species protect them from underwater herbivores, both fish and invertebrates. When growing underwater, Podostemaceae populations are inhabited by numerous animal species, often preserved accidentally in herbarium specimens. While some of these animals may use the plants for shelter and reproduction, others appear to graze the plants, chewing away their leaves and scale-leaves, which likely reduce their ability to photosynthesise and so to reproduce. An anonymous reviewer pointed out that the bracts of some Asian Podostemoideae, e.g., Cladopus, also have dense silica bodies on the surface which render the bracts harder and which may play a role in the protection of flowers.

\section{Inflorescences}

Inflorescences in most species are borne terminally on long or short stems densely clad in scale-leaves and leaves. These last two structures often form a cup inside which the spathellum is developed and partly protected (Thiv et al. 2009). In a few species the stems immediately below the flower have only (short) dichotomous leaves (e.g., I. achoundongii, I. adamesii) and the scale-leaves are placed further down the stem.

Inflorescences appear to arise as single flowers in the axils of the pseudo-dichotomous forks, e.g., in I. ntemensis, or they can be multi-flowered fascicles as in I. feika and I. cussetiana.

In species such as I. feika, few-flowered inflorescences arise directly from the thallus-root on shoots only 1-2 mm long. These shoots are clad in scale-leaves and subtended by a reduced leaf (Fig. 2, 3).

The spathellum varies from globose (I. tenax) to narrowly obovoid and stipitate (e.g., l. thollonii). An apical rostrum is developed in $I$. cristata. In herbarium specimens, spathellae are concolorous with the leaves and stems, except in I. tenax where the spathellum dries purple.

The flower is inverted within the spathellum, rupturing the apex to achieve anthesis as the pedicel expands and the flower 
rotates to the vertical position (Moline et al. 2007: f. 2E). This is triggered when plants are exposed to air. Plants growing under the water surface that have fully formed spathellae can be triggered into anthesis overnight within 12 hours by exposing them to air inside a plastic bag (Cheek pers. obs. 1995-2016).

The pattern of spathellae rupturing can vary from one species to another, some species tending to have a single lateral longitudinal split, others three more or less equal apical triangular lobes, but there is variation within species, and within specimens, reducing the taxonomic value of this character.

\section{Tepals}

The tepals are two, except in very rare monstrous flowers that have three. Tepals are concolorous with the pedicel and gynophore and appear to have no attractive or other functional value. In c. $90 \%$ of the species they are subulate and their length ranges from $0.3-0.8 \mathrm{~mm}$. In I. annithomae, I. adamesii, and I. torrei they can reach $1 \mathrm{~mm}$ long. The longest tepals are recorded by us in I. thollonii $(1.2-1.5 \mathrm{~mm}$ ) and the shortest are noted in I. warmingiana $(0.2 \mathrm{~mm})$. Exceptionally, in I. feika, the apex of the tepal is slightly spatulate.

\section{Androecium}

The androecium has either one or two stamens. In some species both three and two stamened androecia occur in some populations (I. tchoutoi pers. obs., I. annithomae: Cusset 1983: f. 6: 8). The number of stamens, proportions and length of the androphore and its branches, all have some taxonomic value at the species level. The pedicels are reported as pink in I. tchoutoi (Letouzey 15539), and in other species the staminal filaments and/or ovary are described as red, and the anthers white. Flower colour may thus have a role in attracting pollinating insects. No direct observations of pollination are recorded for Inversodicraea, but we contend that Apis mellifera, the honey-bee, is likely to be the main pollinator, since this species has been observed to visit flowers of Ledermanniella on several occasions and at several locations (Cheek pers. obs.). Pollen is produced as either dyads or monads, depending on species; but otherwise no systematic study of pollen has been made for Inversodicraea. Monads are more or less spherical and tricolpate. Among the six species of Podostemaceae studied in detail by Lobreau-Callen et al. (1998) was Inversodicraea (Ledermanniella) ledermannii, which they illustrate in their f. 2F-I. They describe the mesocolpial tectum as echinulate and continuous, its thickness equal to that of the average of the infratectum and of homogenous texture, with imperfectly compacted sporopollenin. The infratectum is stated to be of large irregular lumps united to the tectum or elongated radially, resembling irregular columns, resting on a foot-layer which is very thin and discontinuous. The endexine is thick, in two layers and weakly sculpted. On the lateral faces at the periphery of the areas united in dyads, the tectum is thinner and continuous, forming ectexine bridges between the monads.

\section{Gynoecium}

The gynoecium, produced on an erect gynophore, is usually ellipsoid, oblong-ellipsoid or fusiform, and terete in transverse section, when alive or preserved in spirit. Laterally compressed or flattened ovaries and fruits occur in I. feika and I. cussetiana. The compression occurs in the plane intersecting the commissural ribs. These species would have been referred to the genus Macropodiella in previous classifications (Cusset 1983, 1987).

\section{Locule number, placentation, ovules, and seeds}

Thiv et al. (2009) found that the fruit and ovary appear to have a single locule with free axile placentation (the placenta attached at base and apex only). However, Engler (1915) depicts, e.g., I. cristata as being bilocular, the septa occurring in the plane connecting the commissural ribs. We assume that Engler's depiction is an error since our own observations (this paper Fig. 1-8) confirm those of Thiv et al. (2009). The placenta appears to be ellipsoid in shape, but the careful study by Kita et al. (2008) of $I$. ntemensis showed the presence of an incomplete septum, suggesting that two locular ovaries may have been ancestral. Such detailed studies of placentation are rare in Inversodicraea and study of the other species might reveal additional cases. Detailed comparative studies are lacking on the ovules and seeds. About 50-150 ovules and seeds are developed, the seeds being approximately ellipsoid and having a mucilaginous outer coat, as usual in African Podostemaceae.

\section{Stigmas}

Stigmas number is generally two, but in I. ntemensis and I. tchoutoi, three stigmas are present. Three stigmas occur in the Tristichoideae which are sister to all other Podostemaceae (Koi et al. 2012). It is possible that the three stigma character-state arose from 'switching-on' genes that had long lain dormant in the Podostemoideae genome. However, it is more likely that this is simply an aberrant form of the 2-merous flower usual in Podostemoideae since the rest of the flowers of the species concerned remain bimerous and not trimerous. It is difficult to explain how this unique synapomorphy occurs in such otherwise morphologically dissimilar species that co-occur at the same site unless one invokes horizontal gene transfer.

Generally the stigmas are filiform or linear and about 0.7-0.8 $\mathrm{mm}$ long, but in $I$. fluitans and $I$. tenax they are $1.2 \mathrm{~mm}$ long (Cusset 1983). In I. gabonensis, I. congolana, I. pygmaea they are $0.3 \mathrm{~mm}$ long, and in $I$. harrisii $0.2 \mathrm{~mm}$. The stigmas are thicker, c. $0.15 \mathrm{~mm}$ wide, approaching botuliform in $I$. ebo. In I. feika the stigmas resemble those of Dicraeanthus being narrowly triangular and erect, tapering from a broad base to an acute apex.

\section{Fruit}

On drying, longitudinal ribs are visible in the developing fruits. These correspond with vascular bundles within the pericarp. As the fruit develops, these bundles are exposed at the surface by shedding of the ovary epidermis (Thiv et al. 2009) making the ribs more pronounced. Most Inversodicraea appear to have eight equally developed ribs. Two of these, on opposite sides of the fruit, the commissural ribs, are longitudinally bisected by lines of dehiscence, allowing the fruit to split on drying into two more or less equal valves. In some species the commissural ribs are barely thickened in comparison with the remaining ribs, and the fruits then appear 6-ribbed (e.g., I. adamesii, I. liberia). In I. congolana, I. eladii, I. ebo and I. digitata, either the median or all the non-commissural ribs are winged in the distal part of the fruit.

Fruit dehiscence, we postulate, is due to differential effects of drying on the ribs. The non-commissural ribs tend to contract and straighten on drying more than do the commissural ribs. We postulate that this is due to the non-commissural rib bundles being longer, extending down the pedicel (see below) while those of the commissural ribs do not. In fact the commissural ribs may lack vascular bundles, as is indicated in a transverse section of the ovary of I. cristata (Engler 1915: f. 180K). The results are visible in the deformed shape of the valves postdehiscence when they are longer along the axis of the median non-commissural rib than in the undehisced fruit. The drying stresses rupture the fruit along the preformed lines inside the commissural ribs. In several species (e.g., l. feika) only one of the two suture lines opens, but in most species the fruit splits 
into 2 valves which remain joined only at the gynophore. In several species, e.g., I. xanderi, loss of epidermis and cortical tissue extends down the gynophore, exposing the 6 vascular bundles that descend down the pedicel from the fruit valves where they form the non-commissural ribs.

\section{HYBRIDISATION}

Species hybridisation is reported here for the first time in Podostemaceae. Intermediate specimens between co-occurring species have been observed by us at two locations, involving a total of four species:

1. at the Seli/Rokel river near Bumbuna in Sierra Leone, intermediates and so potential hybridisation between I. ledermannii and I. harrisii;

2. at the Lobé Falls in Cameroon where intermediates are present between I. ledermannii and both I. eladii and I. bosii.

The specimens and characters evidencing this phenomenon are detailed below under the accounts of the species concerned. We conjecture that while hybridisation may be breaking down the barriers between species and allowing gene-flow, it may also support speciation.

\section{ECOLOGY}

Inversodicraea, as with most Podostemaceae, only grow at sites with permanent, or more usually seasonally, fast flowing, silt-free water, or with water spray and splashes. They are always associated with waterfalls and rapids, apparently requiring highly aerated water and a rock substrate. Additionally, Inversodicraea occur mainly where such sites occur in lowland rainforest (below $800 \mathrm{~m}$ alt.). At the Lobé Falls in Cameroon, three species occur just above sea-level. Inversodicraea are usually absent from waterfalls and rapids in woodland (savannah) habitat. Exceptionally, I. fluitans, I. digitata, and I. warmingiana of Angola occur in rapids in woodland habitat at high altitude, above $1000 \mathrm{~m}$. The second of these species occurs at $1640 \mathrm{~m}$, the upper altitudinal limit of the genus. Inversodicraea species are completely absent from the main watercourses of the large rivers of the Nile, the Niger, and the Congo, although one species is present in the Zambesi, e.g., at the Victoria Falls. We conjecture that this is because where falls exist in these rivers the water is too turbid to support Inversodicraea, although Ledermanniella is present abundantly in the falls of the Congo River at and below Brazzaville and Kinshasa. Support for the argument that Inversodicraea cannot grow in turbid water can be found at Kisangani where the clear-water Tshopo joins the Congo River. Immediately above the confluence, the Tshopo drops over two small sets of falls a few metres high, and about $800 \mathrm{~m}$ apart. Here occurred both I. congolana and Leiothylax quangensis (Léonard 1993). In contrast, the Boyama or Wagenya Falls which start at Kisangani on the Congo and continue upstream over a stretch of c. $100 \mathrm{~km}$, with six sets of falls, each of c. $5 \mathrm{~m}$ height, lack Podostemoideae, and both aforementioned genera have not been recorded, despite the falls being in every other way conducive to the growth of Podostemaceae. The difference in turbidity levels between the Tshopo and Congo at the confluence can be easily detected by eye when viewing Google Earth imagery, the first appearing black (silt absent), the second brown (silt abundant) (see Fig. 1 caption for georeference).

Most falls at which species of the genus have been recorded are open to full sunlight, being in large, broad, sometimes braided, rocky, river beds. At these sites they are sometimes associated with other rheophytic species from diverse families and genera, e.g., Karima (Euphorbiaceae), Cheek et al. (2016).
Although Podostemaceae can also occur in diverse rheophytic communities in shaded sites, generally Inversodicraea species tend to be absent (e.g., Cheek in Cheek et al. 2004: 49). Inversodicraea pepehabai is thought to be an exception in occurring in shaded sites. Where more than one species of Podostemaceae occur at a site, they can be partitioned by lighting and/or by depth in the watercourse (Cheek et al. 2004: 49) or by the amount of aeration ('violence') of the water (Léonard 1993). Generally short-lived, annual species such as I. ledermannii occur highest up the river bank. These areas are the last to be inundated when the wet season begins, and the first to be exposed when levels begin to drop as the dry season begins. Long-lived, probably perennial, larger species with rubbery stems generally occur at lower points in the river bed.

\section{Habitat partitioning}

At most sites from which Inversodicraea has been recorded, only a single species of the genus is known, but at several sites, two or even three species have been recorded. At three such sites there is some evidence of habitat partitioning within the genus, while for a fourth, the available evidence does not support this.

\section{Port Loko, Sierra Leone.}

At this site I. ledermannii, a small erect, $2-4 \mathrm{~cm}$ tall annual species, is abundantly present on the upper part of the rocky banks of the river. It is exposed, flowers, then fruits and dies early in the dry season, in October-November as water levels fall. In contrast, I. feika, a large, up to $80 \mathrm{~cm}$ long, flowing stemmed, apparently perennial species remains submerged in deeper parts of the river, only beginning to flower when exposed in December and continuing at least until March, towards the end of the dry season when water levels are lowest (observations by Ben Pollard, Sue Frisby, and Xander van der Burgt).

\section{Memv'ele Falls, Bongola, Cameroon.}

The three species of Inversodicraea at this site differ radically from each other in form and size, suggesting that they fill different niches.

Inversodicraea achoundongii plants are $<1 \mathrm{~cm}$ tall (exceptionally $2 \mathrm{~cm}$ ) with minute stems.

Inversodicraea tchoutoi plants are stout-stemmed, erect, subshrubby plants $10-15 \mathrm{~cm}$ tall. The plants are gregarious forming carpets over the rock. It is possible that they and $I$. achoundongii are sustained in growth by spray for most of the year, rather than being submerged.

Inversodicraea ntemensis has long stems c. $20 \mathrm{~cm}$ long that appear to flow in the current. We conjecture that it remains submerged in deeper parts of the watercourse, as is usual, in our

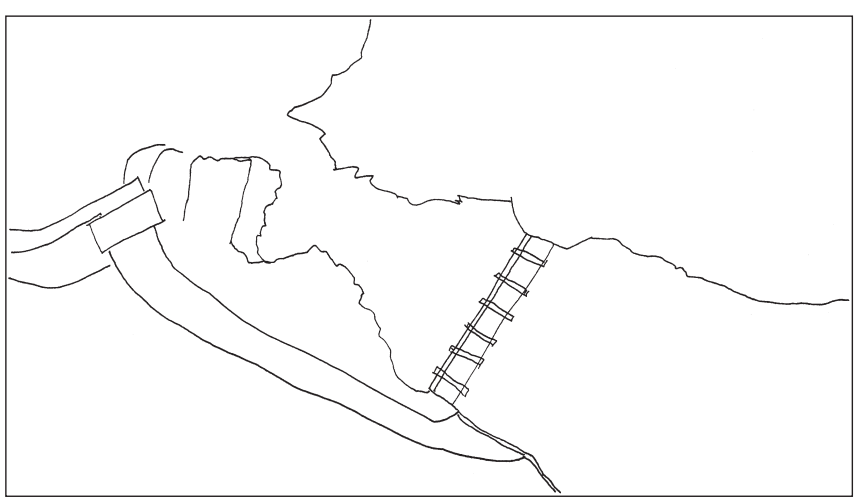

Fig. 1 The hydroelectric power plant at Tshopo River Falls, Kisangani, DRC, N0³2'17.03” E25 11'14.29”. Showing layout of 1950s constructed ROR hydropower installation which preceded the local extinction of $I$. congolana at one of its only two global sites. From Google Earth imagery dated 11 Jan. 2016 (Digital Globe). — Drawn by Martin Cheek. 
experience, with species of this habit. Additional Podostemaceae present at this location are: Macropodiella heteromorpha, Ledermanniella pusilla, Tristicha trifaria, Ledermanniella sp.

3. Rapids on Ogooué, near Booué, above Lopé, Gabon.

Here I. thollonii (N. Hallé \& Le Thomas 206), a small, apparently annual plant with slender erect stems c. 1-2 cm tall, appears with the larger, more robust $I$. annithomae, which has long stems up to c. $25 \mathrm{~cm}$ long that flower while floating on the water (N. Hallé \& Le Thomas 202b). Other species of Podostemaceae that were collected at this site by the same collectors at the same day in July in successive collecting numbers were: Macropodiella heteromorpha (Baill.) C.Cusset $(201,204)$, M. hallaei C.Cusset (203), Ledermanniella pusilla (202) and L. nicolasii C.Cusset (205).

4. The Lobé Falls near Kribi, Cameroon are a touristic attraction, with waterfalls tumbling in a series directly into the sea, across a sandy beach. They have also been an attraction to podostemologists, since ten species of Podostemaceae (including $I$. eladii, published in this paper) have been documented at this locality, a record for Africa:
1. Dicraeanthus africanus
2. Inversodicraea bosii
3. Inversodicraea eladii
4. Inversodicraea ledermannii
5. Ledermanniella batangensis
6. Ledermanniella bifurcata
7. Ledermanniella linearifolia
8. Ledermanniella pusilla
9. Ledermanniella variabilis
10. Tristicha trifaria

There is no data to suggest that the three species of Inversodicraea at this site are separated by habitat partitioning. All three are small erect annual herbs it appears. All three species have been found in mixed collections with other Inversodicraea at this site, and hybrids between I. bosii and I. ledermannii have been suggested (this paper).

This location was first collected for Podostemaceae more than 100 years ago. Karl Ledermann was among the first botanists to visit the locality. After landing at Grand Batanga as part of the German colonial mission to explore and document the hinterland of their new colony, Kamerun, he began his mission of botanical prospection into the interior when he collected many Podostemaceae (Ledermann 1912). Ledermanniella Engl., named in his honour (Engler 1909), although now diminished by the resurrection of Inversodicraea, is still probably the most species-diverse genus of the family in Africa.

It is generally only possible to study Podostemaceae in their natural habitat when the water level drops seasonally, at which time they are exposed to air and triggered into flowering. Seedling establishment, and their development into adult plants, have not been recorded in Inversodicraea, and neither have observations been recorded on pollination or seed dispersal.

A detailed phytosociological study has been completed at only one site at which Inversodicraea occurred. This was completed in June-July 1947 and May and August 1948, before a hydroelectric dam was installed, but the study was not reported until 45 years later (Léonard 1993). By this time a second study at the site, Nyakabwa (1982) failed to refind the Inversodicraea and other associated rare and specialized waterfall species, leading Léonard (1993) to conclude that they had become locally extinct. The study site is at N0 ${ }^{\circ} 32^{\prime} 17.03^{\prime \prime} \mathrm{E} 25^{\circ} 11^{\prime} 14.29 "$ ", at an altitude of $400 \mathrm{~m}$ where the clear water of the Tshopo River flows in rapids and falls over micaceous sandstone rock into the turbid water of the Congo River at Kisangani in Democratic Republic of Congo (DRC). The flow rate of the Tshopo at this point is given as $100-700 \mathrm{~m}^{3}$ per second, at a velocity of 5-6 $\mathrm{m}$ per second at the falls. The water is $\mathrm{pH} 6.6-6.8$, at a temperature of $26-28{ }^{\circ} \mathrm{C}$ when measured in January and June in 1987. Mineralization of the water was reported to be weak, below that of the Congo itself. The dominant cation is $\mathrm{Ca}^{2}+$, the anion $\mathrm{HCO}_{3}$. The annual fluctuation in water level is $4-5 \mathrm{~m}$, with high water periods occurring twice per year, April-May and October-December. The junction of the rivers is marked by the great falls, which vary from 11.2-13.8 $\mathrm{m}$ high depending on the height of the Congo River. About $120 \mathrm{~m}$ further upstream, over a section of rapids in the Tshopo, are the small falls, $3.2 \mathrm{~m}$ high. In this study area 36 different transects were placed, analysis of which showed 6 different communities, each equating to a habitat. Two of these communities contained Podostemaceae:

1. 'Tristicha and Philonotis' (the globally most widespread Podostemaceae, and a moss) occurs on rocks which are not violently battered by water, but which are periodically inundated and under spray at low water periods.

2. 'Leiothylax and Ledermanniella' (Leiothylax quangensis and Inversodicraea congolana, both Podostemaceae) occurs on rocks which are violently hit by water, and underwater all year or more usually exposed at low water. This community is only present at the large and small falls, or in portions of the rapids.

Inversodicraea congolana was recorded in four of the eight transects of the second vegetation type. It occurred in each transect with 2-7 other species, most frequently Leiothylax quangensis which occurred in all eight transects. In two of the four I. congolana plots, cyanobacteria Pleurocapsa minor occurred, and in one also Tolypothrix sp. The moss Philonotis hastata also occurred in two of the transects, while Fissidens bessouensis, F. sylvaticus, Philonotis brevicuspes, Hyophila involuta, and Glossadelphus congolensis each also occurred in one of the Inversodicraea transects.

\section{GEOGRAPHY}

Inversodicraea species occur from Guinea-Bissau in West Africa to Tanzania in East Africa, and as far south as Namibia. They are absent from the Sahel and North Africa. However, although the 30 species of the genus occur in 17 countries, species densities and endemism are highest in West-Central Africa. East and south of DRC, apart from Angola (5 species, of which 2 are endemic), no country has more than one species of the genus. Cameroon has the highest number of both total species (11) and endemic species (8), followed by Gabon (7/2), Sierra Leone, and Guinea-Conakry (both 5/3). The Dahomey Gap (White 1983) is evident for the genus, since no species are recorded at present for the four countries between Ivory Coast and Cameroon. Upper Guinea (sensu White 1983 (west of the Dahomey Gap)), with 9 endemic and 1 widespread species is the second most important centre of diversity for the genus, following Lower Guinea with 14 endemic and 1 widespread species. Within Lower Guinea, the Cross-Sanaga interval (Cheek et al. 2001) is evident, since within the interval itself, only 1 species is recorded, while between the Sanaga and Congo Rivers occur 13 endemic and 1 widespread species.

Of the 30 known species, 18 are point endemics, at once placing them at high risk of extinction from development, and also indicating areas important for plant conservation. The resurgence of interest in the concept and move to implementation of Important Plant Areas in the Tropics (IPAs or TIPAs) has provided impetus to the authors for this study (Darbyshire, continuously updated, Darbyshire et al. 2017). 


\section{THREATS}

\section{Threats to Inversodicraea species}

The principal threats to Inversodicraea species apply equally to Podostemaceae as a whole. Being restricted to habitats with clean, non-turbid, aerated water, with a rock substrate, degradation of these environmental factors pose threats. Because so many Podostemaceae species, including Inversodicraea, are restricted to only one or two locations, they are especially vulnerable. A threat at even one location is likely to pose a high extinction risk for any Inversodicraea present.

\section{Turbidity and eutrophication threats}

Turbidity in the water, indicating that silt is present, can reduce establishment of seedlings (Philbrick \& Novelo 1995). It can also reduce photosynthesis during the main growth period, when plants are under water in the wet season. (Cheek et al. 2015).

Algal growth can blanket Podostemaceae plants at some sites and reduce their ability to photosynthesise. Such growth appears to be associated with nutrient addition to rivers from human populations that may use water courses for processing crops, cleaning, and removal of waste-products. Inversodicraea feika (this paper) appears to be threatened in this way.

\section{Hydroelectric Power Project threats}

The greatest threats to Podostemaceae are from hydroelectric projects which have been growing rapidly in number in recent years as a source of cheap, greener energy. While hydroelectric projects have many environmental benefits compared with alternative options, all too often they threaten Podostemaceae species with extinction. In many cases dams are constructed just above rapids or falls so as to benefit from the vertical drop in water levels (the 'head') at these sites (Fig. 1). Construction of dams may directly impact upon the falls and the species that they contain. More usually dams negatively affect populations of Podostemaceae through changes in water flow by four different threats:

Threat 1 - Reduction of water flowing over falls at the dam site. Water is rerouted in penstocks, which are canals or pipes around the falls, feeding turbines below, before the water re-enters the watercourse below the falls (Fig.1). In extreme situations this can result in the prevention of $95 \%$ of the former discharge water flowing over the falls. Without adequate water flow every year, Podostemaceae cannot survive. More usually, water flow over the falls can be expected to continue via spillways when the dam reservoir is full, typically in the second half of the rainy season, but flow is stopped or reduced at the beginning of the rainy season, so that the number of months for which the flow of water over the falls is continuous, that is, the growing season for Podostemaceae, is reduced, and may be insufficient to allow them to reach reproductive size before the water level drops at the beginning of the dry season. This is thought to have been a factor in the likely extinction of Ledermanniella lunda at the Dundo dam in Lunda Norte, Angola (Cheek et al. 2015).

Threat 2 - Impounding of water by the dam creates a large reservoir of motionless, non-aerated water in which Podostemaceae cannot survive. When the reservoir covers rapids or falls upstream of the dam, any Podostemaceae at these sites will be killed as is predicted at the Bumbuna phase 2 dam in Sierra Leone (Cheek et al. 2017), which threatens Ledermanniella yiben Cheek, an endemic Podostemaceae. Run-of-the-River (ROR) hydroelectric projects (such as the Tshopo project, Fig. 1), do not create large reservoirs and are feasible where river water flows are aseasonal, or in cascade systems (Threat 4 below).

Threat 3 - Disruption downstream of natural season fluctuations in flow. The purpose of a dam is usually twofold:

a. to raise the head of water available to generate electricity; and

b. to produce a reservoir (except in ROR projects) so that water is in place to generate electricity even in the dry season when natural water flow drops below that which is needed to operate the turbines.

With the reservoir in operation, water can re-enter the watercourse below the dam, through the turbines in the dry season. This can result in preventing the usual dry season drop in water level which is necessary to trigger flowering and subsequent seed production, compromising the maintenance of Podostemaceae at rapids and falls downstream of the dam. An example of this is the effect of the Lom Pangar dam on the Sanaga River of Cameroon which has resulted in the global population of Ledermanniella sanagensis (situated downstream at the Nachtigal Falls - themselves the subject of a proposed hydroelectric project by EDF) being kept underwater, and so not producing seed, throughout the dry season of 2015 and 2016 (Ghogue pers. comm. 2017).

Threat 4 - Annihilation of all Podostemaceae habitat. Cascade projects are designed to harness the potential hydropower of entire river systems so as to convert it into electricity through a series of dams along the length of a river, potentially submerging permanently all rapids and falls, and so destroying all Podostemaceae present. Effectively such systems extend and intensify Threat 3 ). In comparison, the other threats above are modest. An example of a completed dam cascade is that of the Lancang River of China, where a cascade of nine dams has been constructed (Wang et al. 2013).

Cascade systems are under development along the Sanaga River of Cameroon, of which the Lom Pangar dam is potentially the first of several dams, and also the Ogooué River of Gabon, of which the Grand Poubara is again only the first element. The Kwanza of Angola and the Cunene of the Angolan/Namibian border, are set to be the first completed cascade systems in Africa.

In this paper we expose the threats to numerous species of Inversodicraea from dams, mainly through paths 1) and 3):

Path 1 - At the Memv'ele Falls dam nearing completion in S. Region, Cameroon, three Inversodicraea species, each recently discovered and globally unique to the falls, are threatened by reduction of water flow over the original falls. These are I. ntemensis (Kita et al. 2008), I. achoundongii (Schenk et al. 2015) and $I$. tchoutoi (this paper). In the same way, I. congolana is thought to be extinct at the Tshopo Falls in DRC due to the construction of a dam on one of the falls, and the reduction of water flow over the main falls.

Path 3 - Along the length of Kwanza (Cuanza) River in Angola, multiple hydroelectric projects threaten I. warmingiana, I. fluitans, and I. digitata. On the Ogooué River of Gabon, I. annithomae and I. thollonii are considered to be at risk from the Grand Poubara project upstream.

\section{DISCOVERY}

The first published species of the genus that would come to be known as Inversodicraea was Podostemum thollonii collected in 1887 by Thollon in present day Gabon (Baillon 1890). This was followed by Sphaerothylax warmingiana collected in Namibia by Baum in 1900 (Gilg 1901). Kolbe then collected 
I. tenax at Victoria Falls in 1906 (Wright 1909). Inversodicraea cristata, I. kamerunensis, and I. ledermannii were all published by Engler (1915) from collections in Cameroon made by Ledermann in 1908. In 1944 I. congolana was published from DRC (Haumann 1944).

Hess's collections from Angola in the 1940s and 1950s, combined with those of Gossweiler, resulted in the publication of I. digitata and I. fluitans (Hess 1953). Inversodicraea abbayesii, I. pygmaea, I. adamesii were collected in the 1940s and 1950s mainly by Prof. des Abbayes and Peter Adames in Guinea and/ or Sierra Leone (Taylor 1953).

Georges Le Testu collected specimens in 1925-1928 from Gabon and Congo-Brazzaville that were, together with collections by Nicholas Hallé, Annique Le Thomas, Paul Sita, Claude Farron, and others later to be published as I. gabonensis, I. boumiensis, I. paulsitae by Cusset (1983). At the same time she published I. bosii, I. torrei, I. mortonii, and I. harrisii, all named for their principal collectors, and made respectively in Cameroon, Mozambique and Sierra Leone and Guinea. Her publication, with eight new species, was the greatest increase in numbers of species of the genus, then formulated as Ledermanniella subg. Phyllosoma (Cusset 1983). Inversodicraea ntemensis and $I$. achoundongii (Kita et al. (2008), Schenk et al. (2015)) were the only two new species to science published in the subsequent 30 years.

The six new species to science added to this genus will not be the last. It is expected that botanical surveys of the many rapids and waterfalls of Africa that have never been inspected for Podostemaceae will produce additional new species to science. Revision of the few widespread and variable species may also result in discovery of additional new species.

\section{TAXONOMY}

\section{Inversodicraea Engl. ex R.E.Fr.}

Rheophytic, hermaphroditic, annual and probably perennial herbs with narrowly ribbon-like, endogenously branching roots, gripping the substrate with adhesive root hairs (also known as rhizoids), distinct haptera (marginal disc-like holdfasts) rarely observed and not well-developed. Stems $<1 \mathrm{~cm}$ to $80 \mathrm{~cm}$ long, branched or unbranched, erect and free-standing in absence of water, or horizontal, flowing in the current. Scale-leaves more or less spirally inserted, rarely in loose whorls, more or less covering the stems, dorsiventrally flattened, about as long as wide, appressed to stem or spreading, margin entire or variously toothed or lobed, rarely the scale-leaves long and awnlike (I. mortonii). Leaves deciduous (shed before flowering as plants are exposed by falling water levels), alternate, appearing 1-5 times dichotomously branched, blade and petiole terete or dorsiventrally compressed, petiole not sheathing, stipules absent. Spathellae single, terminal, rarely appearing axillary, containing a single, inverted flower, rupturing before anthesis. Pedicel expanding to lift the flower from the spathellum. Tepals 2 , usually filiform, inconspicuous at junction of androphore (or united staminal filaments) and gynophore. Stamens two (rarely three as monstrosities), with filaments more or less united at the base into the androphore, sometimes with a single stamen only, anthers tetrasporangiate, connective inconspicuous, pollen in dyads or monads, tricolpate. Ovary with short gynophore, unilocular with axile placentation (attached at base and apex only), ellipsoid to oblong-ellipsoid in side view, cylindrical or laterally compressed in the plane of the two sutures, becoming 6-8-ribbed longitudinally in fruit (the sutures with or without ribs), the ribs sometimes distally produced as wings. Ovules numerous, anatropous, completely covering the placenta. Styles 2 (3 in I. ntemensis and I. tchoutoi), filiform with acute apex and minutely papillate, rarely triangular or slightly botuliform. Fruit dry, dehiscent by (1-)2 valves. Seeds numerous ellipsoid, released dry, epidermis mucilaginous and adhesive on wetting.

Distribution - Tropical Africa, Guinea-Bissau to Tanzania and South to Botswana, 30 species.

Note - Engler coined the name Inversodicraea and formally published it as a new name, giving himself as author (Engler 1915). However, he appears to have been pre-empted in use of his name by Fries (1914) who while attributing it to Engler used the name first, to accommodate Dicraea tenax of Wright (1909). Thus Fries' use of the name has priority over that of Engler according to the Code. The type species of Inversodicraea is thus I. tenax (C.H.Wright) R.E.Fr., being the only species on which Fries (inadvertently) based the new genus.

\section{The application of Inversodicraea}

Inversodicraea was used by Engler (1915) to include many African taxa which were thought to have inverted flowers in their spathellum. These included taxa currently treated as Ledermanniella thalloidea, Macropodiella pellucida, L. aloides, L. batangensis, L. minima, etc., as well as I. cristata, I. kamerunensis. Thus Engler's concept for Inversodicraea was broad. This use was continued with some adjustments until Cusset (1974) pointed out that Ledermaniella Engl. (1909) was the earlier name. She then transferred most names from Inversodicraea into Ledermanniella (Cusset 1974).

With the discovery through molecular phylogenetic research (Moline et al. 2007, Thiv et al. 2009, and Schenk et al. 2015) that Cusset's Ledermanniella subg. Phyllosoma was both coherent and not immediately connected phylogenetically with Ledermanniella subg. Ledermanniella sensu Cusset (1983), the decision was made to elevate it to generic rank, for which the earliest available name was Inversodicraea.

\section{Generic delimitation}

Species of the resurrected Inversodicraea (Ledermanniella subg. Phyllosoma as erected, delimited and revised by Cusset (1983)) are easily recognised due to the unique synapomorphy (derived feature) in having their stems more or less densely covered in (usually) spirally inserted, dorsiventrally flattened, often lobed, rarely needle-like, scale-leaves or 'leaflets' or 'feuillettes', often in addition to larger, but caducous, branched, filiform dichotomous leaves which are also commonly seen in other African Podostemaceae. Such scale-leaves are otherwise absent in African Podostemaceae-Podostemoideae. Inversodicraea are also distinct from, e.g., Ledermanniella, in having terete or slightly flattened petioles and lacking sheathing stem bases and stipules (see Morphology section).

The key to species below is based on that of Cusset (1983) with modifications. In the course of constructing the key, it became necessary to incorporate two newly described species from Cameroon, I. ntemensis Y.Kita, Koi, Rutish. \& M.Kato (2008) and I. achoundongii J.J.Schenk, Herschlag \& D.W.Thomas (2015). These two species share an architecture unexpected in Inversodicraea. The scale-leaves neither a) densely clad the entire stem, as in I. cristata group, nor b) densely clad the spathellae-bearing spur shoots but are absent or only sparsely scattered on the main stems as in the I. annithomae group. Instead these species show a third pattern, c) the spathellae are surrounded by dichotomously branched leaves while the scaleleaves occur thinly scattered on the main axis only. Placement inside Inversodicraea of $I$. ntemensis and $I$. achoundongii has been confirmed by molecular phylogenetic analysis (Schenk et al. 2015). Pattern c) appears to be shared by the little known I. thollonii (Baill.) C.Cusset from Gabon. 
These three species are additionally unusual in the unspecialised shape and margin of their scale-leaves which are triangular, or triangular-ovate with an irregular margin. In contrast, most Inversodicraea have scale-leaves which are often diagnostic of the individual species, having species-specific shape and marginal lobing or other ornamentation. Only I. bosii C.Cusset seems to come close to these group c) species in having scaleleaves lacking marginal ornamentation, although they have a species distinctive ovate-oblong shape.

Observations that species with only a few, sparse, sometimes inconspicuous scale-leaves can be placed in Inversodicraea prompted a reassessment of the recently described Macropodiella cussetiana Cheek \& Ameka. This species, clearly a Macropodiella sensu C.Cusset (1978) since it has laterally compressed ovaries and fruits, also had puzzling unspecialised leafy scale structures discussed in Cheek \& Ameka (2016). One of the new species in this paper, I. feika also has strongly laterally flattened ovaries and fruit (and so initially was to have been described as a Macropodiella) yet is undoubtedly an Inversodicraea due to its typically shaped scale-leaves which are arranged in pattern b). It became clear in preparing this paper that Cusset's (1978) concept of Macropodiella, based solely on the laterally flattened ovary feature (in separating it from Ledermanniella s.lat.) was flawed. Cusset's concept had been questioned already in Cheek \& Ameka (2016) when three groups of Macropodiella species each with their own different architectures were posited to have closer affinities to species in other genera than to each other.

Macropodiella cussetiana had been placed in one of these groups together with $M$. garrettii (C.H.Wright) C.Cusset and M. macrothyrsa (G.Taylor) C.Cusset. All three species have anomalous small unspecialised leafy structures that were characterised as 'bracts' by Cusset (1978), presumably since they are associated with the spathellae. However, bracts have not been convincingly demonstrated in African podostemoids apart from the spathellum itself. We postulate that these leafy structures are in fact scale-leaves homologous with those that uniquely characterise Inversodicraea in Africa. Accordingly, Macropodiella cussetiana is here transferred to Inversodicraea. We hesitate from reinstating the remaining two species there, where they had earlier been placed by Taylor (1953), because their 'bracts' differ from those known so far in Inversodicraea. In M. garrettii they are dichotomous, and in M. macrothyrsa they are stem-sheathing and only present as single structures subtending a spathellum. Their homology with the scale-leaves of Inversodicraea remains to be confirmed.

\section{KEY TO SPECIES OF INVERSODICRAEA}

1. Scale-leaves densely covering (by $50 \%$ or more) both the principal stems and the side-branches (if any) . . . . . 2

1. Scale-leaves only on the side-branches and/or absent to sparsely covering (<40\% cover) the principal stems . 17

2. Scale-leaves entire or sometimes with $1(-2)$ shallow lateral

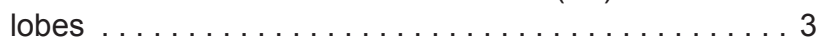

2. Scale-leaves always $3-15$-lobed or toothed, lobes usually deep (but covering $<10 \%$ of the leaflet length in $I$. congolana) . . . . . . . . . . . . . . . . . . . . 9

3. Scale-leaves linear-subulate. - Sierra Leone 1. I. mortonii

3. Scale-leaves ovate, orbicular, or obovate, apex dentate,

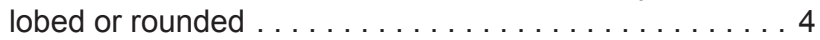

4. Scale-leaves longer than wide, often with 1-2 shallow lateral lobes ......................... 5

4. Scale-leaves orbicular or ovate, unlobed. - Gabon ..... 3. I. boumiensis
5. Scale-leaves \pm patent or spreading, covering c. $50 \%$ of the stem, sometimes with $1-2$ side lobes . . . . . . . 6

5. Scale-leaves \pm appressed to the stem, covering $70-100 \%$ of the stem, lacking side lobes $\ldots \ldots \ldots \ldots \ldots$

6. Flowers with 1 stamen, fruit with 8 ribs. - Guinea . . . . $\ldots \ldots \ldots \ldots \ldots \ldots \ldots \ldots$ 23. I. pepehabai

6. Flowers with 2 stamens, fruit with 6 ribs. - Liberia .... 30. I. liberia

7. Scale-leaves broadest in the distal half, apex broadly convex. - Cameroon ... . . . . . 17. I. kamerunensis

7. Scale-leaves broadest in the proximal half, tapering towards a slender apex . . . . . . . . . . . . 8

8. Flower with 1 stamen; scale-leaves on proximal third of principal stem more than twice as long as broad. - Gabon, Congo ... . . . . . . . . . . . 2. I. gabonensis

8. Flower with 2 stamens; scale-leaves on proximal third of the stem more than twice as long as broad. - Gabon . .

19. I. thollonii

9. Scale-leaves digitately $5-15$-lobed or toothed . . . . 10

9. Scale-leaves 3(-4)-lobed . . . . . . . . . . . . 14

10. Apex of leaflet lobes rounded; stamen 1. - Angola ...

4. I. digitata

10. Apex of leaflet lobes acute; stamens 2 (where known) 11

11. Scale-leaves, in addition to the marginal teeth or lobes bearing 4-10 spines on abaxial surfaces. - Cameroon

26. I. xanderi

11. Scale-leaves teeth or lobes on margin only, projections absent from abaxial surfaces . . . . . . . . . . . 12

12. Leaflet lobes $8-14$, tine-like; ovary and fruit apex winged. - Cameroon .................... 25. I. ebo

12. Leaflet lobes $5-11$, triangular; ovary and fruit without wings

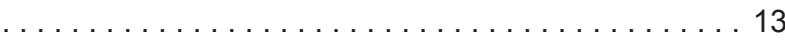

13. Scale-leaves about as long as wide, scale-leaves at stem base tridentate, pedicels $5-10 \mathrm{~mm}$ long in fruit. - Cameroon, C.A.R. . . . . . . . . . . . . . 5. I. cristata

13. Scale-leaves twice as long as wide, scale-leaves at the stem base entire, rounded; pedicels $14-15 \mathrm{~mm}$ long in fruit. - Cameroon . . . . . . . . . . . . . 28. I. tchoutoi

14. Scale-leaves flat with only 3 straight lobes at apex. . 15

14. Scale-leaves not flat, the 3 apical lobes curved inwards, and a fourth curved, reflexed lobe on the abaxial surface. - Guinea, Sierra Leone . . . . . . . . 7. I. harrisii

15. The three lobes triangular, subequal . . . . . . 16

15. The three lobes linear, the central lobe twice as long as the two lateral lobes. - Guinea. . . . . . 8. . . pygmaea

16. Leaflet oblong, the lobes minute, apical, occupying only c. $10 \%$ of the length of the leaflet and shorter than the width of the unlobed part of the leaflet . . 6. I. congolana

16. Leaflet palmate in outline, the lobes occupying 40-50\% of the length of the leaflet, and longer than the width of the unlobed part of the leaflet. - Guinea to Angola

9. I. ledermannii

17. Principal stems $>20 \mathrm{~cm}$ long, lax, flowing in the water and lacking scale-leaves; scale-leaves dense on spur shoots $<1 \mathrm{~cm}$ long . . . . . . . . . . . . . . . . 18

17. Principal stems either $<20 \mathrm{~cm}$, and/or erect, and/or with at least some scale-leaves present . . . . . . . . . 21

18. Principal stems unbranched along their length . . . . 19

18. Principal stems with several major branches along their length. . . . . . . . . . . . . . 20

19. Scale-leaves broadly elliptic, finely denticulate. - Gabon . . . . . . . . . . . . . . . . . 10. I. annithomae

19. Scale-leaves with three equal lobes. - Gabon, Congo 11. I. paulsitae 
20. Apex of ovary and fruit with 6 short wings. - Angola ... $\ldots \ldots \ldots \ldots \ldots \ldots \ldots$ 12. I. warmingiana

20. Apex of ovary and fruit lacking wings. - Angola ..... $\ldots \ldots \ldots \ldots \ldots \ldots \ldots \ldots \ldots \ldots \ldots$ 13. I. fluitans

21. Principal stems $>20 \mathrm{~cm}$ long, flowing in water . . . 22

21. Principal stems $<20 \mathrm{~cm}$ long, usually $1-12 \mathrm{~cm}$ long, erect . . . . . . . . . . . . . . . . . . . . 24

22. Fruits and ovary strongly laterally compressed, usually not in axils of pseudo-dichotomies . . . . . . . . . 23

22. Fruits and ovary terete (not compressed), usually single in axils of pseudo-dichotomies. - Cameroon.........

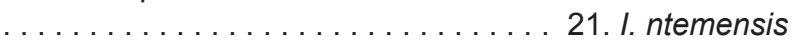

23. Scale-leaves subtending each spathellum c. 10 , often with a lateral lobe; stigmas triangular. - Sierra Leone .....

\section{I. feika}

23. Scale-leaves subtending each spathellum 1-2, entire, stigmas linear. - Ivory Coast . . . . . . 27. I. cussetiana

24. Scale-leaves with projections on the abaxial surface. Tanzania to Botswana . . . . . . . . . . . . . 14. I. tenax

24. Scale-leaves without projections on the abaxial surface

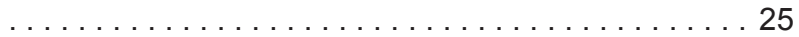

25. Scale-leaves needle-like, not lobed (but with two short lateral lobes at stem apex with spathellae). - Guinea ...

15. I. abbayesii

25. Scale-leaves triangular, ovate, or oblong, apex entire or lobed . . . . . . . . . . . . . . . . . . . 26

26. Plants $1(-2) \mathrm{cm}$ tall, scale-leaves \pm uniformly equilaterally triangular, not lobed. - Cameroon . . 22. I. achoundongii

26. Plants $>2 \mathrm{~cm}$ tall, scale-leaves ovate, oblong, sometimes

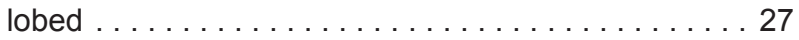

27. Scale-leaves mostly (90\%) ovate, entire (near spathellae slightly lobed). - Cameroon... . . . . . . . . 16. I. bosii

27. Scale-leaves not ovate, but oblong, broadly or narrowly, and lobed. . . . . . . . . . . . . . . 28

28. Scale-leaves as long as broad, or slightly longer (near spathellae needle-like), ovary apex winged. - Cameroon . . . . . . . . . . . . . . . . . . . . . . 29. I. eladii

28. Scale-leaves twice to four times longer than broad, ovary apex unwinged . . . . . . . . . . . . . 29

29. Scale-leaves about twice as long as broad, ovary and fruit 6-ribbed. - Guinea, Sierra Leone. . . . . 20. I. adamesii

29. Scale-leaves about four times as long as broad, ovary and fruit 8-ribbed. - Mozambique . . . . . . . . . 18. I. torrei

\section{SYNOPTIC SPECIES TREATMENTS}

\section{Inversodicraea mortonii (C.Cusset) Cheek}

Inversodicraea mortonii (C.Cusset) Cheek in Cheek \& Haba (2016a) 2. Ledermaniella mortonii C.Cusset (1983) 368, f. 1. - Type: Morton in SL 2899 (holotype WAG n.v.; isotype K), Sierra Leone, Gbenge Hills, opposite Bumban School, fl., fr., 28 Nov. 1965.

Etymology. Named for the collector of the type specimen, Prof. Morton, botanist, specialist in West African Labiatae, Compositae, and Commelinaceae who was based in Sierra Leone and Ghana in the 1960s and 1970s, concluding his career at the University of Waterloo in Canada.

Distribution - Sierra Leone.

Habitat \& Ecology — 'Stem creeping over wet smooth rocks of drying-out stream'; 5-225 m altitude.

Conservation - Inversodicraea mortonii is not listed on www.iucnredlist.org. Two locations only are known for this species. Despite targeted searches for Podostemaceae in Sierra Leone 2009-2016 for the Bumbuna and Yiben hydroelectric projects, and for the Tonkolili iron project, I. mortonii has not yet been rediscovered. Inversodicraea mortonii has not been seen for over 35 years. However, neither of the two known localities for this species are known to have been searched at the correct season. Since we know of no immediate direct threats at either of the two localities, the species is here assessed as Near Threatened. Given that the area of occupancy can be estimated as $2 \mathrm{~km}^{2}$ using the preferred IUCN cell size of $1 \mathrm{~km}^{2}$, I. mortonii should be reassessed as Endangered, EN B2 ab(iii) should any threat materialise, such as a hydroelectric or mining project.

Additional specimen. SierRa Leone, Rapids, $4.2 \mathrm{~km}$ downstream of Mano, Taia River (River Jong, River Pampam), N8 ${ }^{\circ} 01^{\prime}$ W12 ${ }^{\circ} 07^{\prime}$, fr., 28 Feb. 1981, P.J.C.Harris 12 (P00179338 image).

Note - Remarkable for the uniformly subulate (awl-like), linear-conical scale-leaves with rounded apices. Unlikely to be confused with any other species.

\section{Inversodicraea gabonensis (C.Cusset) Cheek}

Inversodicraea gabonensis (C.Cusset) Cheek in Cheek \& Haba (2016a) 2. - Ledermanniella gabonensis C.Cusset (1983) 368, f. 2. - Type: Le Testu 6017 (holotype P00179287 image), Gabon, Haut Ngounyé (now Ngounié Province), 'rapides de l'Ogoulou à Mitingo', fl., fr., 19 July 1926.

Etymology. Named for Gabon, the home of the type specimen.

Distribution - Congo-Brazzaville, Gabon.

Habitat \& Ecology — In the spray of waterfalls in small rivers or streams in the evergreen forest zone; 200-600 m altitude.

Conservation - Inversodicraea gabonensis is not listed on www.iucnredlist.org. The only known location is upstream of the nearly completed hydroelectric dam at the Imperatrice Falls on the Ngounié so is expected not to be affected. Two other locations occur in the Republic of Congo. The first at Foulakari is a local tourist destination near Brazzaville. The second remote in the upper headwaters of the Nyanga in Massif du Chaillu near the Gabonese border. No threats have been detected by us at these locations. However, we have made no direct observations. Given an area of occupation of $3 \mathrm{~km}^{2}$, this species would be assessed as Endangered, EN B2 ab(iii) if any threat were known. Since we know of no threats at these localities, the species is here assessed as Near Threatened. Given that the number of hydroelectric projects in Africa is increasing rapidly, such threats might materialise at any time.

Additional specimens. Gabon (type), Congo-Brazzaville (Republic of Congo), Chutes de Foulakari, fl., fr., 13 Aug. 1969, Attims 202 (P00179288 image); ibid., fr., 13 Oct. 1968, F. Hallé 1467 (IEC, P00179289 image); ibid., fr., 6 Sept. 1972, Sita 3448 (IEC, P00179291 image); Chutes de la Nyanga à Mouvoungou, fl., 18 May 1925, Le Testu 5459 (P00179290 image).

Note - Similar to I. tholloni, I. kamerunensis, I. boumiensis (also C. Africa), I. pepehabai and I. liberia (W. Africa) in having scale-leaves membranous, irregularly or not lobed, loosely held or spreading (not appressed) on slender, sparsely branched, short (2-5 cm long) more or less erect stems. Distinct for the lanceolate scale-leaves often with a side lobe, apices rounded, flowers 1-anthered, pollen in monads.

\section{Inversodicraea boumiensis (C.Cusset) Cheek}

Inversodicraea boumiensis (C.Cusset) Cheek in Cheek \& Haba (2016a) 2. - Ledermanniella boumiensis C.Cusset (1983) 370. - Type: Le Testu 6536 (holotype P00179270 image; isotype P00179271 image), Gabon, Mbigou, Chutes de Boumi, fl., fr., 5 July 1927.

Etymology. Named for the Boumi Falls of Gabon, only known location for the species.

Distribution - Gabon. Known only from the type.

Habitat \& Ecology - Rapids; 600-700 m altitude. 
Conservation - Inversodicraea boumiensis is listed on www.iucnredlist.org as VU D2 (Vulnerable). It was assessed in 2007 (Ghogue 2010c). Cheek (Onana \& Cheek 2011) assesses it as EN B2 ab(iii), that is Endangered. However, both assessments follow the protologue (Cusset 1983) which asserts that the species occurs at the Ntem Falls of Cameroon as well as the type locality in Gabon. Yet, the plants at Ntem ascribed to this species are shown in this paper to be $I$. tchoutoi (see that species). Currently the species is known only from the type locality, falls near Mbigou on the Boumi, a tributary of the Ngounié River in the Province of that name. Assigning an area of occupancy to this species of $1 \mathrm{~km}^{2}$ would result in an assessment of Critically Endangered, CR B2 ab(iii) if any threat were known or to appear. Since we know of no threats at either of these two localities, the species is here assessed as Near Threatened.

Notes - In describing this species, Cusset (1983) cited Letouzey 15339 from the Ntem River in Cameroon in addition to the type from Gabon. Examination of this Letouzey specimen at YA showed it to be I. tchoutoi (see discussion under that species). Therefore, I. boumiensis is known only from Gabon. Inversodicrea boumiensis resembles I. gabonensis, the type of which was collected within some tens of kilometres. They differ in that the first has pollen in dyads from flowers with two stamens, while I. gabonensis has monads and one stamen.

\section{Inversodicraea digitata H.Hess}

Inversodicraea digitata H.Hess (1953) 363, t. 8/3. - Ledermanniella digitata (H.Hess) Cusset (1974) 273; (1983) 372. - Type: Hess 50/239 (lectotype ZT n.v., isolectotype BM), Angola, Benguela, 'In einem Seitenfluss des Rio Catumbela, dem Rio Cubal da Hanha, zirka $50 \mathrm{~km}$ südlich Vila Mariano Machado [Ganda], auf zirka $1400 \mathrm{~m}$ Höhe gefunden. Der Cubal bildet dort Falle von etwa $2 \mathrm{~m}$ Höhe. Die Pflanze wurde erst am Ende der Trockenzeit gesammelt', fl., fr., 29 Aug. 1950.

Etymology. Named for the shape of the leaflet lobes which resemble the fingers of a hand, with rounded tips.

Distribution - Angola.

Habitat \& Ecology - Waterfalls with Hydrostachys polymorpha Klotzsch (Hess 50/232); 1000-1642 m altitude.

Conservation - Inversodicraea digitata is not listed on www. iucnredlist.org. Since three locations are known, and the area of occupancy can be calculated as $3 \mathrm{~km}^{2}$, and since two of those two locations are in the Cuanza (Kwanza) drainage, we here assess the species as EN B2 ab(iii). Podostemaceae on the Cuanza are threatened (where they still exist) by the four hydroelectric dams which have changed the natural annual fluctuation of water levels. In 2014 (http://www.hydroworld. com/articles/2014/09/angola-plans-five-hydroelectric-projectson-middle-cuanza-river.html accessed 17 Feb. 2017) it was announced that five new, additional dams are to be constructed on the Cuanza.

Additional specimens. Angola, Cuanza Sul, Mussende, R. GangoCuanza, 1000 m, fr., 13 June 1930, Gossweiler 9291 (BM, COI n.v., K, ZT n.v.); Bié Province, Cuquema River (Kwanza drainage), 13 km WSW of Kuito, S12 25'32" E1649'6", 1642 m, fl., 19 May 2015, Goyder 8001 (K); ibid., st., 8 Feb. 2016, Goyder 8203 (K).

Notes - Although Cusset (1983) stated that the holotypes of Hess's 1953 names are at ZT, specimen locations are not given in the protologue, so lectotypification is needed. The ZT duplicate is therefore formally selected as lectotype since Hess is believed to have been based there.

Gossweiler 9291 (BM), previously cited by Cusset (1983) as I. cristata, is here recognised as a second record of $I$. digitata in view of the single stamen. This specimen was compared with the type of $I$. digitata at BM.
This species is similar to $I$. warmingiana and $I$. fluitans, also in Angola. It differs in that the leaflet lobes are finger-shaped: each is parallel-sided with round apices (not acute) according to the figure in Cusset (1983). The flowers have 1, not 2 stamens, and the stems are short, not more than $20 \mathrm{~cm}$ long. However, the leaflet lobes in the specimens seen are acute. Either the Cusset figure is misleading or the unseen type number at $\mathrm{ZT}$ differs from the remaining material in this respect.

The two Goyder specimens (8001 and 8203) represent the highest altitudinal record for the genus at $1642 \mathrm{~m}$ above sealevel. The first is in full flower but lacks leaves, while the second, from the identical spot but collected in the wet season while under water, has both fully developed and unfolding leaves but is sterile. Unusually in the genus, the ovaries dry red, and are reported as being red in life.

\section{Inversodicraea cristata Engl.}

Inversodicraea cristata Engl. (1915) 276, f. 180A-M; (1926) 462; (1930) 58. - Ledermanniella cristata (Engl.) C.Cusset (1974) 273; (1983) 372; (1987) 74. - Type: Ledermann 1173 (B holotype destroyed, lectotype selected here BM; isotype U n.v.), Cameroon, 'Makaka' (Makaka Station), 'gr. Steine \& Felsen in reissendem Bach im gebirgigen Walde'. 'Podostem. mit grünlichen BI. und rosaroten Blütenstielen', fl., fr., 21 Nov. 1908, 500 m.

Etymology. Cristata meaning 'crest' may refer to the crest-like arrangement of tine-like divisions along the apex of the scale-leaves.

\section{Distribution - Cameroon.}

Habitat \& Ecology - Rapids; 520-780 m altitude.

Conservation - Inversodicraea cristata is listed (as Ledermanniella) on www.iucnredlist.org as VU B2 ab(iii) in 2007 by Ghogue (2010d). That assessment follows the protologue of Cusset (1983) which recognises the species as extending to Angola, C.A.R., Equatorial Guinea, and Gabon, as well as Cameroon. Yet, in studying these specimens for this paper, it was discovered that the only authentic records of this plant appear to be from Cameroon alone (see above). However, at the time of writing, not all of the specimens attributed by Cusset to I. cristata have been viewed and identified and therefore a formal reassessment of its conservation assessment cannot yet be made. However, the species is very likely threatened.

Additional specimens. CAMEROon, Maan (24 km ESE Nyabesan), rochers du lit du R. Mvigili, dans la NW du village, fl., fr., 6 Mar. 1963, J.\& A. Raynal 10263 (P00179279 image; P00179280 image, YA); Mali, R. Fall, c. 8 km N. Bétaré Oya. fl., 5 Feb. 1966, Leeuwenberg 7761 (P00179278 image, WAG n.v., YA).

Notes - Ledermanniella cristata is the type of Ledermanniella subg. Phyllosoma C.Cusset (1983). Cusset's delimitation of this subgenus is followed here, albeit elevated to generic level, as Inversodicraea, for which the type selected is I. tenax.

The protologue of I. cristata Engl. (1915) cites no specimen but the figure is a good match for the BM sheet of Ledermann 1173 , the number generally understood to be its basis (e.g., cited in Engler (1926) and cited as type by Cusset (1974) and so is selected as lectotype here. Cusset's (1983) concept of $I$. cristata was broad, including discordant elements. For example, Gossweiler 9291 (Angola) is in fact I. digitata (see under that species), while Tisserant 3210 (C.A.R., 'Riv. Koyali, Bozoum', 7 Jan. 1933, P00179281 image; P00179282 image) has an uncertain placement, needing further research. Neither of these specimens matches the illustration in the protologue, nor the type specimen itself, which has 9-12 long, slender, tine-like scale-leaf lobes. Therefore the material assigned to this species requires reassessment since more than one species is probably involved. 


\section{Inversodicraea congolana Hauman}

Inversodicraea congolana Hauman (1944) 179; (1948) 244. - Ledermanniella congolana (Hauman) C.Cusset (1974) 273; (1983) 374. - Type: Vanderijst 21682 (BR n.v.), Congo-Kinshasa (DRC), Chutes de Luilu, Thielen St. Jacques, fr.

Etymology. Named for the Congo (now DRC) to which this species is endemic.

\section{Distribution - DRC.}

Habitat \& Ecology - Rapids; $300-775$ m altitude.

Conservation - Inversodicraea congolana is not listed in www.iucnredlist.org. It was only known from two falls. The first was at the set of falls on the Tshopo where a hydroelectric dam has been installed since the species was collected. Here the Tshopo joins the Congo near Kisangani, DRC's third largest city. It is notable that there are no records of Inversodicraea from the vastly more extensive Wagenya (Boyama) Falls, also at Kisangani, but on the Congo River itself. These falls extend upriver for about $100 \mathrm{~km}$ in a series of step falls none more than $5 \mathrm{~m}$ vertically. This absence is probably due to the high silt levels of the water of the Congo River, which viewed on Google Earth are brown, unlike the clear water of the smaller Tshopo River.

The second location for the species was also recorded in the grasslands of the Kasai at Thielen St Jacques, now MweneDitu, specifically at Chutes de Luilu on a braided river where no obvious threats are visible on Google Earth. Accordingly we calculate the area of occupancy as $2 \mathrm{~km}^{2}$. Construction of the dam at the Tshopo Falls is thought to have impacted on the species, principally by reducing the total volume of water flowing over the falls (much has now been diverted around the falls via a penstock) and also by disrupting the natural seasonal water flow regime at the falls, constituting threats. According to Léonard (1993), citing Nyakabwa (1982), I. congolana, which he discovered and surveyed at the site in 1947, no longer occurs there and is locally extinct. Therefore we assess the species as Endangered, EN B2 ab(iii). A survey for the species at the Tshopo site is still advisable to determine whether or not some last few plants might still survive there.

Additional specimen. DRC, Kisangani, Chutes de Tshopo, fr., July 1947, Léonard 1346 (BR n.v.).

Note - This is the sole member of the genus known from DRC apart from I. tenax towards the southern border. Inversodicraea congolana occurred at two isolated locations: 1) in the forest belt almost within the city limits of Kisangani; and 2) in the Kasai grasslands towards the border with Angola. These two locations are so far apart, and in such different vegetation types that both specimens deserve comparison to confirm that they are indeed conspecific. Neither specimen has been examined in this study since BR specimens were not accessible in $2016 / 2017$ owing to a digitisation programme. Inversodicraea congolana is distinctive for its pair of ovary apical wings, derived from the two median longitudinal ovary ribs. The same character occurs in I. warmingiana of Angola (but on all six longitudinal ribs) and in I. feika of Sierra Leone, I. eladii and I. ebo of Cameroon. Inversodicraea congolana is also unusual in having dorsal protuberances on its leaflet. It is unique in the genus in combining this character with winged ovaries.

\section{Inversodicraea harrisii (C.Cusset) Cheek}

Inversodicraea harrisii (C.Cusset) Cheek in Cheek \& Haba (2016a) 2. Ledermanniella harrisii C.Cusset (1983) 374, f. 5. - Type: Harris 41 (P00179305 image holotype), Sierra Leone, rapids at Dodo ferry crossing to Magbwema, river Sewa, N750" W11 ${ }^{\circ} 44^{\prime \prime}$, fl., fr., 8 Dec. 1981.

Etymology. Named for Prof. P.J.C. Harris, Agricultural Scientist, University of Coventry, United Kingdom, the collector of the type specimen and most of the original material.
Distribution - Guinea-Conakry (Republic of Guinea) and Sierra Leone.

Habitat \& Ecology - Rapids in rivers of evergreen forest areas; $60-280 \mathrm{~m}$ altitude.

Conservation - Inversodicraea harrisii is not listed on www. iucnredlist.org. Five locations are known (above), equating to an area of occupancy of $5 \mathrm{~km}^{2}$. Its location in Guinea on the Bafing River is threatened by the planned Koukoutamba dam for which construction bids were sought in 2016 (https://www. africa-energy.com/article/guinea-omvs-develop-koukoutambahydro-scheme accessed 17 Feb. 2017). This threatens the species through both permanent flooding and arresting of the flow of water in the reservoir part of the project, and the disruption of the natural cycle of water levels below the dam. The second location, on the Sewa River, is thought to be threatened by high levels of diamond extraction upriver, which places silt into the water, reducing both seedling establishment and photosynthesis for Podostemaceae downstream. Finally, the location at the site of the Bumbuna-Yiben hydroelectric dam is thought to be in the process of being lost. Accordingly the species is here assessed as Endangered, EN B2 ab(iii).

Additional specimens. GuInEA-ConAKRY, Haut Bafing, près Socotoro, fr., Apr. 1905, Chevalier s.n. (holotype P00179299 image). - SIERRA LEONE, rapids of the river Sewa at Dodo to Magbwema, N7 ${ }^{\circ} 50^{\prime \prime}$ W11 ${ }^{\circ} 44^{\prime \prime}$, fl., fr., 8 Dec. 1981, Harris 41 (P00179305 image holotype); ibid., Harris 37 (P00179301 image); ibid., Harris 38 (P00179302 image); rapids near Mofwe, River Sewa, N7 ${ }^{\circ} 40^{\prime \prime}$ W11 ${ }^{\circ} 58^{\prime \prime}, 8$ Dec. 1981, Harris 34 (P00179300 image); River bridge near Baiima, River Tabe N806" W11 51", 8 Dec. 1981, Harris 46 (P00179303 image); Road bridge 2 miles SW of Lengkoro, River Mawaloko, N9 27" W11ํ⒉4", 10 Dec. 1981, Harris 71 (P00179304 image); Koinadugu District, SE of Fadugu, along Seli (Rokel) river east of Fadugu, upstream of the village of Yiben, to be flooded by proposed dam N9¹8'52.2" W11 ${ }^{\circ} 39^{\prime} 27.5^{\prime \prime}, 260 \mathrm{~m}$ alt., old fr., 31 May 2014, van der Burgt 1840 (BR n.v., K, MO n.v., P n.v., SL n.v., WAG n.v.).

Notes - Unique in West African species of the genus in the single dorsal tooth of the leaflet, more or less equal in size to the lateral teeth-lobes. Those few other species with dorsal projections have much smaller and more irregular protuberances, and none occur in West Africa.

The figure in the protologue (Cusset 1983) shows all of the scale-leaves with the distinctive dorsal spine. However, recent specimens from the Bumbuna area of Sierra Leone such as van der Burgt 1840 (initially identified as L. ledermannii) have only one in five, or one in ten scale-leaves with the spine. It is not clear whether this is because of variation in the frequency of expression through the population, or whether another explanation, such as hybridisation and introgression with I. ledermannii, which also occurs at this location, might be the cause. Alternatively the figure in Cusset (1983) may be erroneous, but this cannot be checked against the original material, all at $\mathrm{P}$, without a physical visit, since resolution of the online digital images is too low for this purpose.

\section{Inversodicraea pygmaea G.Taylor}

Inversodicraea pygmaea G.Taylor (1953) 72, f. 10; (1954) 127. - Ledermanniella taylorii C.Cusset (1983) 376, f. 5 - Ledermanniella pygmaea (G. Taylor) C.Cusset, non L. pygmaea (Pellegr.) C.Cusset (1974) 274. - Inversodicraea ledermannii auct. non. Engl., sensu A.Chev. p.p. (Chevalier 1938: 297). - Type: $H$. des Abbayes 353/1951 (holotype BM), GuineaConakry, 'cercle de Kindia, Grandes-Chûtes, Rochers plats au bord de la rivière au niveau des basses-eaux, parmi les Dicreanthus parmelioides, 4-12-1951'.

Etymology. Named for the diminutive stature of the species ('the pygmy Inversodicraea').

Distribution - Guinea-Conakry.

Habitat \& Ecology - On flat rocks at the edge of the river at low water, among 'Dicraeanthus parmelioides A.Chev.' (= Stonesia) rapids; $230 \mathrm{~m}$ altitude. 
Conservation - Known only from the Grandes-Chûtes of Kindia, which falls give their name to a Forêt-Classé, in the centre of which is a large and expanding bauxite mine operated by Russal (Cheek 2016 pers. obs.). The falls themselves have had their seasonal flow modified by a series of hydroelectric dams upstream, the Baneah and Donkeah dams. These developments are likely to have negatively impacted the Podostemaceae at the falls. However, I. pygmaea may have become extinct after the first hydroelectric project on the river, which was constructed at Grandes-Chûtes, in 1962-1963 by Hidrotehnika of the former Yugoslavia.

Here I. pygmaea is assessed as Critically Endangered, CR B2 $\mathrm{ab}$ (iii), given the single location and threats stated above. The area of occupancy is $1 \mathrm{~km}^{2}$. Inversodicraea pygmaea is not listed on www.iucnredlist.org.

Additional specimen. GuINEA-CONAKRY, cercle de Kindia, Grand-Chûtes, chemin de fer, km 107, fl., 19 Dec. 1908, Chevalier 20232 (P00179378 image).

Notes - Although the trifid leaves are unremarkable, the species is distinctive for its very short $(3(-5) \mathrm{mm}$ tall) erect, stout, stems which are thickly and densely clad in uniformly shaped scale-leaves, from the $0.2 \mathrm{~mm}$ wide ribbon-like root to the terminal spathellae. The spathellae often ruptures into 3 or 4 equal triangular lobes but this varies, with sometimes one large and one small lobe, for example.

The fruits lack commissural ribs, resembling $I$. adamesii in this, but the species differs in gross morphology, stamen number, and other features. The non-commissural ribs project so far that they are narrowly wing-like.

\section{Inversodicraea ledermannii (Engl.) Engl.}

Inversodicraea ledermannii (Engl.) Engl. (1915) 274; (1926) 463; (1930) 58; Taylor (1954) 127. — Dicraea ledermannii Engl. (1909) 381. — Ledermanniella ledermannii (Engl.) C.Cusset (1974) 274; (1983) 377; (1987) 72. — Type: Ledermann 225 (holo B destroyed; isotype BM, U n.v.), Cameroon, S. Region, 'Wasserfall, Gross-Batanga station, 10-12 m, auf Felsen unter wasser oberhalb der Fälle im 'Lobe'. Podostem. Kleines Pflänzchen in Wasser. Blüht weiss-grün, konnt in ganzen kolonien vor.' fl., 10 Aug. 1908.

Etymology. Named for Karl Ledermann the collector of the type specimen, and of specimens that became the types of many other new species of Podostemaceae and other families which were published by Engler.

Distribution — Angola, Cameroon, Gabon, Guinea, Ivory Coast, Sierra Leone.

Habitat \& Ecology - The upper banks of rapids, first to be exposed as the water levels drop at the end of the wet season, in full sun; 0-400 m altitude.

Conservation - Inversodicraea ledermannii (as Ledermanniella) was listed on www.iucnredlist.org as Least Concern in 2009 (Diop 2010c). However, the species is not in fact recorded from some of the countries in which it is claimed to occur in that publication, such as Ghana, Senegal, Niger, Togo, etc. Despite this it is probably, with I. tenax, the most common and widespread species of the genus and therefore we do not contest this assessment.

Additional specimens. Angola, Bengo, River at Bela Vista, Exp. Zool. Staat. 1959 (HBG n.v.). - CAMEROON, SW Region, Korup National Park, N501' E8 ${ }^{\circ} 50 ', 50$ m alt., 5-15 Dec. 1984, D. Thomas 4135A (K, P00179325 image). - DRC, N. Lukafu, valley of Lofoi R., Schmitz 1833 (BR n.v.). - GABON, Rapides de l'Ogooué au passage de la route de Mimongo à Koula Moutou, fr., 25 June 1926, Le Testu 5983 (P00179326 image). - GuINEA, GuinéeForestière, Beyla Prefecture, Mts Bèro, fl., 22 Nov. 2008, P.M. Haba 242 (BR, G, HNG, K, MO, P, SERG, WAG). - Ivory COASt, Mt Cavally, Pays de Dyolas, au pied de Mt Dô, 750 m alt., prés Gouékangouine, st., 2 May 1909, Chevalier 21421 (P00179316 image). - SIERRA LEONE, small waterfall in Rokel River; Kabala to Makeni, Northern province, 22 Mar. 1971, P.W. Richards 7320 (K, P00179375 image).
Notes - This, with I. tenax, is the most widespread and frequent species of the genus. There is a large geographic disjunction between the populations in Guinea-Ivory Coast and those in Cameroon-Angola, and it is possible that these correspond with two different taxa. It is not yet clear how much morphological support there is for this idea. The matter was first discussed by Taylor (1953). Those specimens above not seen by us were studied and cited by Cusset (1983).

The isotype of I. bosii at K appears to be I. ledermannii. Hybridisation and possibly introgression, is suspected to have occurred between I. ledermannii and I. bosii in Cameroon, and with I. harrisii in Sierra Leone (this paper).

Inversodicraea ledermannii is distinctive for the three, more or less triangular, equal, lobes, each of which is about half the length of the entire leaflet and has an acute apex.

Caution should be used before identifying material as this species in West Africa, since material originally identified thus later proved to be separate species, e.g., I. pygmaea and I. harrisii.

\section{Inversodicraea annithomae (C.Cusset) Rutish. \& Thiv}

Inversodicraea annithomae (C.Cusset) Rutish. \& Thiv (Thiv et al. (2009) 72) - Ledermanniella annithomae C.Cusset (1983) 377, f. 6; (1987) 76. Type: N. Hallé \& A. Le Thomas 206 (holotype P00179254 image), Gabon, Booué, lit de l'Ogooué, fl., 29 July 1966.

Etymology. Named for Annique Le Thomas co-collector of the type specimen and a noted specialist of Annonaceae and a palynologist at $\mathrm{P}$.

Distribution - Gabon. Only known from the type specimen at Booué.

Habitat \& Ecology - River rapids of the Ogooué R. '4 espèces en mélange sur rochers' (type, $N$. Hallé \& $A$. Le Thomas 206) with Ledermanniella nicolasii C.Cusset (205), L. pusilla (Warm.) C.Cusset (202), Macropodiella hallaei C.Cusset (203), M. heteromorpha (Baill.) C.Cusset $(201,204)$, I. annithomae, and $I$. thollonii (202bis) at c. $200 \mathrm{~m}$ altitude.

Conservation - Inversodicraea annithomae (as Ledermanniella) was assessed in www.iucnredlist.org as Endangered (EN B2 ab(iii) in 2007 (Ghogue 2010a), and also by Cheek (in Onana \& Cheek 2011), citing only two known locations, one in Cameroon and one (the type) location in Gabon. In this paper, the population in Cameroon is shown to be a misidentification for I. tchoutoi (see above, and under that species). This leaves only a single location, the type, for $I$. annithomae. The area of occupancy is therefore estimated as $1 \mathrm{~km}^{2}$. Given threats from hydroelectric dams on the Ogooué River, of which the Grand Poubara, upstream, that opened in 2013 , is the first, the future for this species is bleak.

Since such dams moderate the natural seasonal fluctuation of water levels downstream, they can deprive Podostemaceae of the drop in water level needed to expose plants and so allow flowering and seed production, and thus regeneration. Accordingly, we here reassess the threat to this species as CR B2 $a b$ (iii), that is Critically Endangered.

Notes - The sterile paratype cited in the protologue, Letouzey 10299, 'Chutes du Ntem ou de Memve'ele, près Nyabessan, $60 \mathrm{~km}$ E Campo (st. avr.)' is a different taxon to that of the type, and is described, with several new, fertile specimens from the same location, as I. tchoutoi in this paper. Inversodicraea annithomae itself, appears to be confined to Gabon and is only known from the type collection. References to $I$. annithomae from the Ntem River of Cameroon, and its appearance in phylogenetic analyses (e.g., Thiv et al. 2009, Schenk et al. 2015) probably refer to $I$. tchoutoi. The differences between the taxa are given in a table in the account for the last species. 
The Paris website lists under this species Sita 5856 (P00179255 image), from Congo, Chaillu, Rapide de Mandoro, 3 ponts, 6 June 1985, identified by C.Cusset in 1998. Since the specimen shown is highly branched, we consider this determination to be unlikely, but image resolution was insufficient to provide an alternative determination.

Inversodicraea annithomae is one of the most distinctive members of the genus. Together with $I$. paulsitae it is unique in having long $(5-25 \mathrm{~cm})$, flexible, unbranched floating stems, with regular internodes, each node with a short, densely leafletclad flowering stem opposite to a long, dichotomously branched leaf. While the last species has deeply 3-lobed scale-leaves, I. annithomae has almost entire scale-leaves.

In fact, at the type location near Booué, six species of Podostemaceae were collected by $N$. Hallé \& $A$. Le Thomas when collecting the type specimen, and probably there are seven since Tristicha trifaria is very likely to be present, being ubiquitous.

\section{Inversodicraea paulsitae (C.Cusset) Cheek}

Inversodicraea paulsitae (C.Cusset) Cheek in Cheek \& Haba (2016a) 2. Ledermanniella paulsitae C.Cusset (1983) 378, f. 7. - Type: Le Testu 6510 (holotype P00179346 image; isotype BM), Gabon, 'Moupoundi, rapide Litsila de la Ngounye', fl., fr., 20 June 1927.

Etymology. Named for Paul Sita, pioneering Congolian forest botanist based at IEC, the National Herbarium of Congo-Brazzaville. He is the author of the first checklist of Congo Plants. He collected one of the original specimens of this species.

\section{Distribution - Gabon, Congo-Brazzaville.}

Habitat \& Ecology - Dans les embruns, waterfalls; 350$780 \mathrm{~m}$ altitude.

Conservation - Inversodicraea paulsitae is not listed on www.iucnredlist.org. It is known from only four locations (see above), equating to an area of occupancy of $4 \mathrm{~km}^{2}$. The Moukoukoulou dam at Mindouli represents a threat to the location on the Bouenza. This dam provides power to Pointe Noire. Constructed in the 1970s, it is possible that the specimen collected at this site (Farron 4581) was made before the dam was constructed and that the species is now extinct at the site, since a survey mission there led by one of us (XVDB) in 2011 failed to find the species.

The location of the Sita 3581 seems to be in the region of the upper reaches of the Nyang at Niari in the Massif du Chaillu. The location of the Beckendorff s.n. location in Gabon, is equally uncertain. The type location, of Le Testu 6510, is on a tributary of the Ngounie. Since all three of these locations are not affected immediately by any known hydroelectric project that we have discovered, the species is probably extant, and possibly secure. However, as micro-hydroelectric projects expand in their geographic range, there is a distinct possibility that more of the locations for I. paulsitae may become threatened. The species is here assessed as Endangered, EN B2 ab(iii).

Additional specimens. Congo-Brazzaville, Mouyondzi, chutes de la Bouenza S35' E1342', fr., 2 Aug.1965, Farron 4581 (P00179347 image); ibid., Divenié, Mission Catholique, sur rochers immergés dans la Bibaka, fr., 28 Jan. 1975, Sita 3581 (IRSC n.v., P00179348 image). - GABON, Riviere Louetoie, Chutes Byoko, 1933, J.J. Eckendorff s.a. (BM).

Notes - Similar and perhaps closely related to $I$. annithomae, the two being unusual in sharing long $(5-25 \mathrm{~cm})$, flexible, unbranched floating stems, with regular internodes, each node with a short, densely leaflet-clad flowering stem opposite to a long, dichotomously branched leaf. Inversodicraea paulsitae is easily separated from $\mathrm{l}$. annithomae by the deeply trifid (not entire or with shallow, irregular, marginal teeth) scaleleaves.
The thick main axes are 10-12 cm long, unbranched except at the base. At anthesis they lack leaves, and bear flowers only from short, $2 \mathrm{~mm}$ long erect, densely leaflet-clad stems which are held in clusters of $4-12$, the clusters are $5-10 \mathrm{~mm}$ diam on the upper side of the main axis.

\section{Inversodicraea warmingiana (Gilg) Engl.}

Inversodicraea warmingiana (Gilg) Engl. (1915) 274; (1926) 462; H.Hess (1953) 365; Obermeyer (1970) 208. — Sphaerothylax warmingiana Gilg (1901) 17; Warm. \& Gilg (1903) 240; Baker \& C.H.Wright (1909) 128; Engl. (1930) 58. - Ledermanniella warmingiana (Gilg) C.Cusset (1974) 275; (1983) 380. - Type: Baum 904 (B destroyed; BM, C n.v., COI n.v., G n.v., K, L n.v., M n.v., U n.v., Z n.v.), Angola, Huíla/Cuando Cubango, Menempremp, near Wolombo, Cubango River, 'Im Kubango bei Menempremp $1300 \mathrm{~m}$ (Wolombo). Abschüssige Stellen des Kutsi (Cuchi) und Kubango (Cubango) ...., fl., 11 May 1900, alt. 1300 m.

Etymology. Named for Johannes Eugen(ius) Bülow Warming 1841-1924, a Danish botanist who wrote the first textbook and gave the first lectures on the subject of ecology. Podostemaceae was reputed to be his favourite plant family, which he researched and published upon in Brazil.

Distribution - Angola and possibly just over the border into Namibia.

Habitat \& Ecology - Waterfalls; 940-1500 m altitude.

Conservation — Inversodicraea warmingiana was listed on www.iucnredlist.org as Vulnerable A3c after an assessment in 2006 (Sieben 2010) which states "a planned dam in the Okovango River will seriously impact the population in Namibia with an estimated $30-50 \%$ of the population that could be lost". This assessment was based on the assumption that the species occurs in Namibia which is unproven (see below), and also the mistaken assumption that "the species is only found in two sites". The first of these two sites is the Ruacana Falls on the border of Angola and Namibia. And there is now indeed a hydro plant on the river there. However, the dam is on the Angolan side, and it looks from Google Earth that the (formerly) suitable territory for the species would also have been on that side. It is expected that both Hess and Exell \& Mendonça collections came from the Angolan side. The second site is in S. Angola, cited as being the Kubango River. However, I. warmingiana is the most commonly collected Inversodicraea in Angola. Apart from the Cubango River, it is known also from the Cunene, Cuanza, Cuchi, and Cutata Rivers, occurring in four provinces of Angola. Yet, since we have not mapped this species, nor collected the data on threats, we do not reassess the species here. Given the number of locations and threats from hydroelectric projects in Angola it is likely that it would be rated as Vulnerable under Criterion $B$ if reassessed.

Additional specimens. Angola, Cunene, 'Prov. Huila. Schnellen von Lacavala (Rio Cunene) 40 km oberhalb', 9 June 1952, Hess 52/1966 (BM, ZT n.v.); ibid., Ruàcanà, c. 1000 m, 8 June 1937, Exell \& Mendonça 2740 (BM, COI n.v); Malanje/Cuanza Sul, Prov. Malange, R. Cuanza, Condo Falls, c. $1000 \mathrm{~m}$, stems fleshy, as thick as a finger, brownish green, fl., 29 Mar. 1937, Exell \& Mendonça 137 (BM, COI); R. Cuanza, bridge between Cabuta and Cassoque, fl., 25 June 1937, Exell \& Mendonça 3085 (BM, COI); R. Cuanza, Port Condo, Gossweiler 14147 (B destroyed, BM, COI n.v., K, L n.v., LISC n.v.); Huíla/Cuando Cubango, Rio Cubango, Aug. 1937, G. Boss in Herb. Trans. Mus. 36671 (BM, PRE n.v.); ibid., In den Fällen bei Vila Ponte [Kuvango], 1380-1450 m, 19 June 1962, Hess 52/2039 (BM, G n.v., UPS n.v., ZT n.v.); Cuando Cubango, Prov. Bié, Falle des Rio Cuchi (Kutsi) im Malova-Gebirge c. 100 km Östlich Vila da Ponte, 1500 m, 25 June 1952, Hess 52/2071 (BM); Huila/Cuando Cubango, Falle des Rio Cutata, 40 km Östlich Vila da Ponte, 1470 m, 20 June 1952, Hess 52/2052 (BM). Further specimens for this taxon are cited in Cusset (1983).

Notes - Unique in Inversodicraea due to the apex of the fruit having six wings, one from each of the non-commissural longitudinal ribs; also it has the highest altitudinal range of all species of the genus. Otherwise, I. warmingiana is closely similar to I. fluitans of Angola, both having oblong-ovate scale-leaves with 
5-7-toothed margins, and long flexible floating stems (30-40 $\mathrm{cm}$, but up to $80 \mathrm{~cm}$ long in I. fluitans) that lack scale-leaves except for the short, flowering side-branches. In this architecture they are similar to I. paulsitae and I. annithomae, but unlike these species, the main stems are branched. Inversodicraea fluitans has an androecium that exceeds the ovary, while that of $l$. warmingiana is minute.

Cusset (1983: 382) reports that specimens from the Cuanza River in Malanje District, Angola, differ in several characters from the remaining specimens of the species. We have not been able to review all the specimens concerned so suspend judgement as to whether these represent a separate taxon or not.

Obermeyer (1970) mistakenly attributes this species to Botswana

Inversodicraea warmingiana is recorded from 14 specimens deriving from three river catchments in Angola (the Cubango and its tributaries the Cutato and Cuchi, the Cunene, and the Kwanza (Cuanza)) and appears to be the most frequently recorded species of the genus in Angola.

Gilg was based in B, but the specimens there were destroyed (Obermeyer 1970: 208), so a lectotype should be chosen from specimens at another herbarium, ideally a specimen seen by Gilg.

\section{Inversodicraea fluitans $\mathrm{H}$. Hess}

Inversodicraea fluitans H.Hess (1953) 364. - Ledermanniella fluitans (H.Hess) C.Cusset (1974) 273; (1983) 382. - Type: Hess 50/83 (isolectotypes BM 2 sheets, BR n.v., G n.v.; lectotype ZT), Angola, Malanje, '...den Fällen von Bragança (Rio Lucala), im Norden von Angola, am 28.7.1950 gesammelt. Die Pflanze werd nur am obern Band der Fälle im ressenden Wasser flutend beobachtet. Sie hat sich dort an Graniten festgesetzt. Höhe zirka 1200 m. Auf Falsen am oberen Ronde der Fälle', alt. 1200 m, fl., fr., July 1950.

Etymology. Presumably referring to the stems which flow in the current of water.

Distribution - Angola.

Habitat \& Ecology - Waterfalls in open, mainly woodland habitat sometimes with Hydrostachys polymorpha (type locality); 50-1200 m altitude.

Conservation - Inversodicraea fluitans is not listed on www. iucnredlist.org. It is known from one location on the Lucala River (tributary of the Kwanza), the Chutes de Bragança (now the Kalandula Falls), and at two locations on the Kwanza (Cuanza) River, at Cassoque-Cabrita, and at Cambambe-Dondo. Using the IUCN-preferred $1 \mathrm{~km}^{2}$ cells for riverine species results in an area of occupancy of $3 \mathrm{~km}^{2}$. Existing threats on the Kwanza are immense. At 2014 the 520-MW Capanda, 700-MW Cambambe 2, 2067-MW Lauca, and the 260-MW Cambambe were already in place or under construction. Studies for CaculoCabaca, Zenzo 1, Zenzo 2, Tumulo do Cacador and Luime new hydroelectric power projects were conducted in 2014 according to Estevao. The Lauca project is under construction by the Brazilian company Odebrecht. The five new projects are to be constructed by Coba (https://constructionreviewonline. com/2014/10/angola-carry-five-hydroelectric-projects/ downloaded 16 Feb. 2017). Therefore at least two, and possibly all three known sites for this species are probably threatened. We here assess the species using IUCN (2012) as Endangered, EN B2 ab(iii).

Additional specimens. AngolA, Malanje, Duque de Bragança, Luando Muba, Lucata, 1000 m, 29 Aug. 1922, Gossweiler 8855 (BM); ibid., Rianondo, 1 Sept. 1922, Gossweiler 8856 (BM); ibid., Loando Muba, 1000 m, 29 Aug. 1922, Gossweiler 8857 (BM); ibid., Quedes de Duque de Bragança [Quedas de Kalandula], E1601' S904', 23 Mar. 1973, 1140 m, Bamps, Martins, M. Silva 4259 (P00179286 image); Cuanza Norte/Bengo, Cambambe-Dondo, Catarata Cuanza, 55 m, fl., Gossweiler 9247 (BM); bridge on R. Cuanza [Kwanza], Cassoque-Cabrita, fr., 25 June 1937, Exell \& Mendonca 3086 (BM, COI n.v.).
Notes - Although Cusset (1983) stated that the holotypes of Hess's 1953 names are at ZT, specimen locations are not given in the protologue, so lectotypification is needed. The ZT duplicate is therefore formally selected as lectotype since Hess is believed to have been based there.

Similar to the more frequently recorded $I$. warmingiana (see there for diagnostic characters), I. fluitans is only known from three locations, all in Angola, at one of which I. warmingiana has also been recorded (bridge on R. Cuanza, Cassoque-Cabrita, Exell \& Mendonca 3085, 3086, COI n.v.).

While the type has $80 \mathrm{~cm}$ long, flowing stems and almost digitate lobes at the apex of the oblong scale-leaves, the remaining specimens are shrubby, with pectinate lobes. The long laciniate, narrow, acute lobes are similar in some respects to those of I. cristata. However, in the 5-7-toothed scale-leaves this species is closest to sympatric $I$. warmingiana, which is distinguished primarily by the 6 -winged apex of the fruit.

\section{Inversodicraea tenax (C.H.Wright) Engl. ex R.E.Fr.}

Inversodicraea tenax (C.H.Wright) Engl. ex R.E.Fr. (1914) 56, t. 11; Engl. (1915) 274; (1926) 462; (1930) 58. - Dicraea tenax C.H.Wright (1909) 125. - Ledermanniella tenax (C.H.Wright) C.Cusset (1974) 275; (1983) 384; (1997) 4, t. 1B; Beentje (2005) 4. - Type: Kolbe 3141 (holotype K; isotype BOL n.v), Victoria Falls, Livingstone Isl., Zambezi River, 'Grows in the very swirl of the rapids. Plant a bronze colour and a horny consistency, affording foothold to crabs', fl., mid July 1906.

Etymology. From the Greek tenax meaning, tenacious, clinging, since this species clings to rocks in rapids (as in fact do all species of the genus).

Distribution - Angola, Botswana, DRC, Namibia, Tanzania, Zambia, Zimbabwe.

Habitat \& Ecology - Forming colonies densely covering rocks in swiftly flowing water at, or just below, water level, flowering above water level (Cusset 1997); 350-1200 m altitude.

Conservation - Inversodicraea tenax is not listed on www. iucnredlist.org since it is so widespread and frequent, being known from 11 locations (our analysis of specimens cited by Cusset (1983)), it falls short of the threshold of 10 locations required to trigger threatened status for non-fragmented species under Criterion $\mathrm{B}$, which is most frequently used for assessing plant species. Therefore we here assess it as Near Threatened (NT). Area of occupancy is estimated as $11 \mathrm{~km}^{2}$ using IUCNpreferred $1 \mathrm{~km}^{2}$ cells. Hydroelectric projects pose threats to this species: 254 such projects occur in Zimbabwe alone.

Additional specimens. ANGola, Moxico, waterfalls near Luso [Luena], Thompson 50 (J n.v.). - BotswanA, Chobe River, 2 miles $\mathrm{N}$ of Kazane, 13 July 1947, Pole-Evans 4214 (K, PRE n.v). - DRC, Dilolo, River Luan, rocks in fast water, 20 July 1932, R.G.N. Young 184 (BM); ibid., 185 (BM); Vallée de la Eofai, au Nord de Lukafu, sur roches ... a sec ou peu immergeuse pendant les derniers mois de le saison seche, 17 July 1948, A. Schmitz 1833 (BM). - NAmiBIA, Caprivi Strip, Zambezi River, Mambova rapids, West 3702 (SRGH n.v.). - TANZANIA, Stromgebeit des Oberen Ruhudje. Landschaft Lupembe, nordlich des Flusses, Aug. 1931, Schlieben 1131A (BM, K). - ZAMBIA, Mwinilunga, Kabompo River where it crosses Mwinilunga-Solwezi Rd, mile 69, 17 Sept. 1952, F. White 3282 (BM); ibid., 23 Oct. 1969, Drummond \& G. Williamson 9262 (P00179370 image). - ZAMBIA/ZIMBABWE BORDER, Victoria Falls, Zambezi River, wet rocks in running water, Worsdell sin, July 1909 (BM); ibid., Cataract Island, July-Aug. 1919, Burtt-Davy 17827 (BM); ibid., July 1926, E.L. Stephens s.n. (BM); ibid., June 1937, Obermeijer 36515 (BM); ibid., 1 Aug. 1941, Greenway 6255 (BM, K); ibid., just above falls on basalt rocks, abundant, flowering just above the water, 17 Aug. 1947, Brenan 7729 (BM, K); ibid., Livingstone Island, 21 Nov. 1949, without moss-like growth, Wild 3129 (BM); ibid., 3000', Eastern Cataract, 6 July 1953, Schelpe 3928 (BM).

Notes - With I. ledermannii the most widespread and frequent Inversodicraea species.

It occurs in every country south of DRC and north of S. Africa except Malawi and Mozambique. The only other species of the 
genus recognised in South-Central Africa is I. torrei (Mozambique, a single location). The projections from the dorsal leaflet surfaces of $I$. tenax distinguish it from most other species and otherwise only occur in I. xanderi, I. harrisii, and I. congolana.

The type species of the genus, first collected on the Zambesi River at the Victoria Falls on the border of Zambia and Zimbabwe (Kolbe 3149, the type location is mistakenly given as 'Tanzanie' by Cusset 1983: 384). We have counted 27 collections made at the type locality from those cited for the species by Cusset (1983). This exceeds all other species of the genus for number of records at one site. By error, these same 27 specimens are all attributed to Tanzania by Cusset (1983).

Curiously, the species had not previously to this paper been reported from DRC, neither by Cusset $(1983,1997)$ nor by Hauman (1948).

Inversodicraea tenax as currently defined is morphologically variable with discordant elements, effectively comprising a species complex that would reward further analysis.

\section{Inversodicraea abbayesii G. Taylor}

Inversodicraea abbayesii G. Taylor (1953) 67; (1954) 126. — Ledermanniella abbayesii (G.Taylor) C.Cusset (1974) 273; (1983) 385. - Type: H. des Abbayes 898/1948 (holotype BM; isotypes U n.v., ZT n.v.), Guinea, Pita, Chûtes Kinkon, 880 m, fl., 22 Feb. 1948.

Etymology. Named for the collector of the type specimen, Prof. H. des Abbayes, of the University of Rennes, Brittany, France, collector of the type specimen.

Distribution - Guinea, endemic.

Habitat \& Ecology - "Tres abondant dans la rivière au dessus des Chûtes, attaché aux rochers dans le courant. Seul le sommet fleuri émerge de l'eau" ( $H$. des Abbayes 898/1948); waterfall, $880 \mathrm{~m}$ altitude.

Conservation - Known from two collections at one location, Chûtes de Kinkon in the Fouta Djalon of Guinea. Inversodicraea abbayesii was listed on www.iucnredlist.org as Data Deficient in 2008 (Diop 2010a) citing the National Monograph of Guinea as evidence that the species, known only from a single location, Chûtes de Kinkon, is not threatened. However, in recent years a Chinese hydroelectric dam has been constructed near the falls. The resultant changes to the natural alternation of water levels may explain why this species has not been recollected since, despite being so close to the major town of Pita. Here the species is assessed as Critically Endangered since there is a single location, with area of occupancy estimated at $1 \mathrm{~km}^{2}$ and with the threats ascribed above: CR B2 ab(iii).

Additional specimens. GuInEA, type specimen; ibid., fl., fr., Dec. 1948, Bourdu s.n. (P00179245 image).

Note - In habit similar to $I$. adamesii but with well-developed commissural ribs, and with scale-leaves much more acute, longer and more slender. The scale-leaves have similarities to the minute I. pygmaea of Grandes Chûtes, Kindia, but the habit, and fruit ribs greatly differ.

\section{Inversodicraea bosii (C.Cusset) Rutish. \& Thiv}

Inversodicraea bosii (C.Cusset) Rutish. \& Thiv (Thiv et al. (2009) 72). Ledermanniella bosii C.Cusset (1983) 385, f. 9; (1987) 78. - Type: Bos 3592 (holotype WAG n.v; isotypes K, P00179266 image, YA), Cameroon, S. Region, S. Kribi, Chûtes de la Lobé, fl., 8 Jan. 1969.

Etymology. Named for the collector of the type specimen, Dr Bos, of the Herbarium Vadense, University of Wageningen (now transferred to Leiden). $\mathrm{He}$ was a noted botanical collector in S. Region Cameroon, and specialist in Dracaena.

Distribution - Cameroon, Chûtes de la Lobé.
Habitat \& Ecology - 'In fast running shallow water on otherwise bare rockfaces' (Bos 3592); in evergreen forest zone; 5-10 $\mathrm{m}$ altitude.

Conservation - Inversodicraea bosii was listed on www. iucnredlist.org in 2007 as EN B2 ab(iii), i.e., Endangered (Ghogue 2010b). Two locations are cited there, the first at Lobé, threatened by tourist trampling, and the second at Campo (no threats listed), with an area of occupancy of $2 \mathrm{~km}^{2}$. The same assessment was made by Cheek (in Onana \& Cheek 2011) additionally citing hydroelectric development as a threat at the Campo (Ntem) location.

In fact (see notes above), we now know that $I$. bosii is known from a single location, the Lobé Falls, at which we assess its area of occupancy (and so its extent of occurrence) as $1 \mathrm{~km}^{2}$ using the IUCN-preferred cells of that size. Here it is threatened by trampling from the many tourists that visit what in Cameroon is a major tourist attraction (Cheek in Onana \& Cheek 2011, Ghogue 2011). Therefore the species is here reassessed as Critically Endangered, CR B2 ab(iii).

Additional specimen. Cameroon, S. Region, S. Kribi, Chûtes de la Lobé, fl., 8 Jan. 1969, Bos 3597 (WAG spirit specimen n.v.).

Note - The paratype of I. bosii, Letouzey 15333 (Chûtes du Ntem près de sa deviation sur le Bongola) is I. ntemensis (see under that species). Inversodicraea bosii is therefore only known from the type locality at Chûtes de la Lobé. The isotype at $\mathrm{K}$ is $\mathrm{I}$. ledermannii suggesting that this number is a mixed collection. The large, entire, ovate scale-leaves described and depicted in the protologue are distinctive. Initially Cusset (in litt. 1975) had determined the type material at YA as Ledermanniella (Inversodicraea) kamerunensis. Elad 1482 and 1484 may be hybrids between I. bosii and I. ledermannii (see discussion under $I$. eladii).

\section{Inversodicraea kamerunensis (Engl.) Engl.}

Inversodicraea kamerunensis (Engl.) Engl. (1915) 274, f. 180N-R; (1926) 463; (1930) 58, f. 47A-D. - Dicraea kamerunensis Engl. (1909) 380, f. 2A-D. - Ledermanniella kamerunensis (Engl.) C.Cusset (1974) 274; (1983) 387; (1987) 76. - Type: Ledermann 440a (holotype B destroyed; lectotype BM selected here), Cameroon, S. Region, 'Schnellen des CampoFlusses, bei Dipika' (falls of the Campo River near Dipika), fr., Aug. 1908.

Etymology. Named for Cameroon (Kamerun is the German spelling) to which country it remains endemic.

Distribution - Cameroon. Only the type gathering is known. Habitat \& Ecology - Waterfalls at low altitude.

Conservation - Apparently not seen for over 100 years, this species is vulnerable to proposed hydroelectric projects on the Campo (Ntem) River, its only known location. Inversodicraea kamerunensis (as Ledermanniella) was assessed as Vulnerable in 2007 (Ghogue 2010e) but in view of imminent construction of the hydroelectric dams upstream of the only known location of this species (see under I. ntemensis) we feel that the threat to the species has risen. Multiple surveys for Podostemaceae along the length of the Campo (Ntem) River in the last 10 years have not succeeded in rediscovering this species suggesting that the $20 \mathrm{~km}^{2}$ area of occupancy estimated in Ghogue (2010e) may be an overestimate, and that $1 \mathrm{~km}^{2}$ is the more realistic estimate and in keeping with IUCN guidance. Accordingly the species is here assessed as Critically Endangered, CR B2 $\mathrm{ab}$ (iii). In Cheek (in Onana \& Cheek 2011) the same assessment was given. It is potentially Extinct.

Notes - According to a note on the type cover at BM: 'Holotype destroyed in Berlin'. On the sheet itself is written in pencil 'Portion returned to B. June 1984. J. Laundon'. The specimen packet is marked 'Dicraea kamerunensis Engl. (portion of type)'. Therefore, with the destruction of the holotype at B in 1943, 
the BM material is here selected as lectotype being the largest remaining portion of the only original specimen mentioned and illustrated in the protologue of the basionym (Engler 1909).

Ledermann 440 is the type of Ledermanniella linearifolia Engl., and also the type of Ledermanniella Engl. The specimen details are identical with those of Ledermann 440a. The numbering suggests that since they are numbered together the two specimens were growing together, and that the suffix 'a' was added later to separate them - a standard convention in this circumstance.

Cusset based her description and illustration (1983) of the species purely on the protologue and its illustration which is misleading in some respects. She was unaware of the BM material it seems, having failed to find the type at B (Cusset 1983). No leaf stipules were seen on the lectotype by us although Cusset states that they are present (Cusset 1983).

The illustration in the protologue is misleading, showing scaleleaves which are linear-oblong, whereas the type specimen has scale-leaves about as long as wide. The scale-leaves broaden slightly from base to apex. The apex is semicircular, and either entire, or minutely and irregularly laciniate.

The affinities of $I$. kamerunensis appear to be with $I$. thollonii (see notes there) and $I$. adamesii.

\section{Inversodicraea torrei (C.Cusset) Cheek}

Inversodicraea torrei (C.Cusset) Cheek in Cheek \& Haba (2016a) 2. - Ledermanniella torrei C.Cusset (1983) 386, t. 10; (1997) 3. - Type: Torre 5515 (holotype LISC n.v.), Mozambique, summit of Serra Gurué near Mt Namuli, fl., 9 Apr. 1943.

Etymology. Named for Antonia Rocha da Torre (1904-?), collector of the type specimen, noted botanist in Mozambique.

Distribution - Mozambique, known only from Serra Gurué near summit of Mt Namuli.

Habitat \& Ecology - No accurate data are available, but rapids above Gurué occur at c. $750 \mathrm{~m}$ altitude (observed on Google Earth).

Conservation - This species is a point endemic on the little available evidence. Rapids along a small river, the Licungo, in a steep-sided valley seen above Gurué town (Google Earth imagery dated 26 Nov. 2015, viewed 22 Feb. 2017) are a possible location for this species. An area of occupancy of $1 \mathrm{~km}^{2}$ can be estimated using the standard IUCN cell size for riverine plants. The river, as habitat for submerged aquatic plants, appears to be at risk from silt from surface run-off, since the east side of the valley had been cleared for agriculture, with bare soil extending to within $20 \mathrm{~m}$ of the watercourse. The western side of the valley was a tea plantation monoculture. Intensive tea plantations were established in the colonial period, and have recently been rehabilitated. Anthropic degradation is extensive and increasing at Mt Namuli. Botanical surveys of Mt Namuli in the early twenty-first century failed to refind any Podostemaceae (Timberlake et al. 2009). It is to be hoped that this was because the species was overlooked and not that it is extinct. Given the apparent threat to, and single location of $I$. torrei we assess it here as CR B2 ab(iii), Critically Endangered. The species has not been listed on www.iucnredlist.org.

Additional specimen. MozAmbIQUe, summit of Serra Gurué near the peak of Mt Namuli, fr., 20 Sept. 1944, Mendonça 2166 (LISC n.v).

Notes - Distinctive for its thinly scattered (covering $<40 \%$ of stem), long slender scale-leaves (length : breadth ratio c. $10: 1$ ) which bear two lateral lobes of the same shape as the main leaflet, and which are held at an angle of c. $45^{\circ}$ from it.

Cusset (1997: 3 ) cites an additional record for this species: 'Botswana N: junction of Linyanti and Zambezi Rivers, fl. vii.
1930, E.M. Young s.n. (BM)'. However, this specimen is discordant from that described in the protologue having, e.g., mainly unlobed scale-leaves and a spathellae with a short rostrum. This specimen may represent an undescribed species, but the spathellae are unopened and flowers invisible. Inversodicraea torrei is known only from a single location, whence last recorded in 1944 , about 70 years ago.

\section{Inversodicraea thollonii (Baill.) Cheek}

Inversodicraea thollonii (Baill.) Cheek in Cheek \& Haba (2016a) 2. - Ledermanniella thollonii (Baill.) C.Cusset (1983) 388; (1984) f. 13. - Podostemum thollonii Baill. (1890) 877. - Type: Thollon 825 (holotype P P00179381 image; isotype BM, P00179380 image), Gabon, Ogooué, Rapides de Lopé, fl., fr., 1887.

Etymology. Named for François-Romain Thollon (1855-1896), an early French botanist in Gabon and Congo and collector of the type specimen

Distribution — Gabon, Ogooué River.

Habitat \& Ecology - Rapids in the Ogooué River; c. 200 m altitude.

Conservation - We here assess $I$. thollonii as Critically Endangered since the natural fluctuations of water flow in the Ogooué River, wherein occur its two sites (one location since facing the same threat), are being affected by the opening in 2013 of the Grand Poubara dam built by China's Sinohydro http://www.gauff.net/en/news/articles/article/beginn-desaufstaus-im-wasserkraftwerk-grand-poubara.html. Among other hydroelectric projects under construction in the area one is also on the major tributary Ogooué River upstream of our species at the Chutes de l'Impératrice (https://www.afdb.org/ fileadmin/uploads/afdb/Documents/Environmental-and-SocialAssessments/CDI\%20R\%C3\%A9sum\%C3\%A9\%20PGES\%20 coder\%20french\%2025-05-12.pdf). The two sites and single location for this species equate to an area of occupancy of $2 \mathrm{~km}^{2}$ using the standard IUCN cell size for riverine plants. This gives an assessment of CR B2 ab(iii). Currently the species is not listed on www.iucnredlist.org.

Additional specimen. Gabon, Booué, lit de L'Ogooué, fr., 29 July 1966, N. Hallé \& A. Le Thomas 202b (P00179379 image).

Notes - Inversodicraea thollonii is still only known from rapids in the Ogooué River of Gabon at two sites which are so close together (a maximum of $36 \mathrm{~km}$ apart, on the same river) that it can be argued that they should be treated as one location since they both face the same threat. The most recent record is over 40 years old. This species is linked with I. kamerunensis and $I$. adamesii by the slender, loosely branched stems, sparsely covered with irregularly 1-3-lobed membranous scale-leaves. These species are also unusual in the elongate spathellum c. 4-7 times as long as broad, and by the androphore exceeding the ovary. Within this group it is distinguished by the soft, entire, nail-like scale-leaves on the middle of the stem, and, but more elongate and curved, at the stem apex.

\section{Inversodicraea adamesii G. Taylor}

Inversodicraea adamesii G. Taylor (1953) 69, f. 9; (1954) 127. — Ledermanniella adamesii (G.Taylor) C.Cusset (1974) 273; (1983) 388. - Type: Adames 177 (holotype K), Sierra Leone, Large Scarcies River, Kambia Bridge, fl., fr., 5 Dec. 1948.

Etymology. Named for Peter Adames (1914-), formerly of the FAO and British Colonial Service, botanist and collector of the type specimen.

Distribution - Sierra Leone, Guinea.

Habitat \& Ecology - Moss-like herb on rocks in Scarcies and Seli Rivers seemingly with I. mortonii (Harris 10 and 12).

Conservation - Inversodicraea adamesii is listed as Data Deficient by IUCN based on an assessment made in 2008 (Diop $2010 b$ ). That assessment mistakenly includes Guinea-Bissau 
as part of the distribution of the species. At that time the current wave of hydroelectric projects were evidently not anticipated and/or unknown, since they were not mentioned among the threats. The species is known from four locations on as many rivers, on two of which, the Kolenté and Seli, multiple industrial projects, mainly hydroelectric, have been and are being, put in place that are disrupting the natural rhythm of water levels and in the case of the Seli, the water quality (iron and gold mining projects). Using the $1 \mathrm{~km}^{2}$ cell size favoured by IUCN for riverine species allows an area of occupancy of $4 \mathrm{~km}^{2}$. Therefore we assess the species as EN B2 ab(iii), that is, Endangered.

Additional specimens. GuInEA, dans le lit de la Kolenté River, st., 30 Dec. 1938, J. Chillou 1039 (P00179246 image). - SierRA LeOne, Kambia, Magbema, Large Scarcies River, fl., 29 Dec. 1951, H.D. Jordan 754 (K); Rapids $200 \mathrm{~m}$ upstream of road bridge across river Seli (Rokel) N8 ${ }^{\circ} 59^{\prime} \mathrm{W} 11^{\circ} 48^{\prime}$, Magburaka-Makeni Rd, fr., 17 Nov. 1981, Harris 10 (P00179247 image); Rapids $4.2 \mathrm{~km}$ downstream of Mano on the Taia river, $\mathrm{N} 8{ }^{\circ} 01^{\prime} \mathrm{W} 12^{\circ} 07^{\prime}$, fl., fr., 21 Nov. 1981, Harris 15 (P00179248 image).

Notes — In his protologue Taylor (1953) cites Espiritos Santos 2760 (K) from Guinea-Bissau, as paratype. Cusset (1983) states that this specimen is certainly not this species because there are eight equal capsule ridges not six. This view is supported here. Cusset concludes that a precise identification of that specimen is not possible because the state of the specimen is too advanced.

No additional specimens of this species have been seen in at least 30 years, despite targeted collecting of Podostemaceae in 2009-2016 in Sierra Leone by Xander van der Burgt and colleagues including Aiah Lebbie and Josef Momoh, mainly in the Seli River.

Inversodicraea adamesii has close morphological affinities with I. kamerunensis and I. thollonii of Cameroon and Gabon. It is distinct inter alia in the absence of commissural ribs.

\section{Inversodicraea ntemensis (Y.Kita, Koi, Rutish \& M.Kato) J.J.Schenk, Herschlag \& D.W.Thomas}

Inversodicraea ntemensis (Y.Kita, Koi, Rutish \& M.Kato) J.J.Schenk, Herschlag \& D.W.Thomas (in Schenk et al. (2015) 542). - Ledermanniella ntemensis Y.Kita, Koi, Rutish \& M.Kato (in Kita et al. (2008) 224). - Type: R. Imaichi, Y. Kita \& J-P. Ghogue CMR-65 (TNS), Cameroon, S. Region, rapids of Ntem River, $2 \mathrm{hr}$ by motorboat from Campo beach, N2 $14^{\prime} \mathrm{E9}^{\circ} 52^{\prime}$, fl., fr., date unrecorded.

Ledermanniella bosii C.Cusset (1983) 385, p.p., quoad Letouzey 15333.

Etymology. Named for the Ntem River (also known as the Campo), the only known location for the species.

Distribution - Cameroon, S. Region, Ntem River, falls near Bongola at Memve'ele.

Habitat \& Ecology - 'On submerged or exposed rocks in waterfalls, only at Ntem waterfall ... grows with Ledermanniella bifurcata (Engl.) C.Cusset' (Kita et al. 2008) and "sur rochers trés exposé aux embruns" (Letouzey 15333); c. 395 m altitude.

Conservation - Inversodicraea ntemensis is known only from the falls both at, and downstream of Memve'ele (a major hydroelectric project under construction, due for completion in 2017). Two additional hydroelectric streams are planned subsequently along the Ntem River (http://china.aiddata.org/ projects/289 downloaded 15 Feb. 2017), one of which is conjectured to be at Bongola itself. Sinohydro are constructing and China Exim Bank financing, the project. The area of occupation (AOO) is estimated as $1 \mathrm{~km}^{2}$. The extent of occurrence (EOO) will slightly exceed the AOO. Given the single location and threat from the hydro project referred to, and EOO/AOO, we here assess this species using the IUCN (2012) standard as CR B1+ B2 ab(i,ii,iv) as Critically Endangered following broadly the assessment of CR B2 ab(iii) given by Cheek in Onana \& Cheek (2011: 250). It is possible that this species will be rendered extinct by the construction and existence of the dam and its modification of seasonal water level changes of the river. The species is not listed on www.iucnredlist.org.

Additional specimens. CAmeroon, S. Region, Canon du Ntem, 30 km SW de Nyabessan, fl., 1 Dec. 1982, Nkongmeneck 420 (YA); Ntem Waterfalls near Bongola, 40 km ESE of Campo, 10 Dec. 1979, R. Letouzey 15333 (P00179267 image, YA 3 sheets); Campo Ma'an area, Memve'ele Waterfalls N2 ${ }^{\circ} 24^{\prime}$ E10 $10^{\circ} 21^{\prime} 48^{\prime \prime}$, fl., fr., 17 Jan. 2002, Tchouto 3373 (K, KRI n.v., SCA n.v., WAG, YA)

Note - Inversodicraea ntemensis, together with I. tchoutoi, also at Memve'ele, are alone in the genus for consistently having 3 (not 2) equal styles. Inversodicraea ntemensis is also unusual for the extremely sparse and inconspicuous scaleleaves which cover less than $5 \%$ of the distal stems and which are reduced to short, narrowly triangular to ligulate structures that appear to be vestigial. The figure in the protologue depicts the scale-leaves occurring in whorls of three. The flowers are single, inserted in stem pseudo-dichotomies. Most of the biomass of the plants is comprised of the stout, branching stems and the numerous dichotomous leaves. This appears to be a perennial species. The species appears restricted to falls in the Ntem River above Campo, near Bongola, at Memve'ele.

\section{Inversodicraea achoundongii J.J.Schenk, Herschlag \&} D.W.Thomas

Inversodicraea achoundongii J.J.Schenk, Herschlag \& D.W.Thomas (in Schenk et al. (2015) 542). - Type: D.W. Thomas 9642 \& G. Achoundong (holotype MO n.v.; isotypes GAS n.v., K, NO n.v., YA, Z n.v.), Cameroon, South Region, forest and banks of Ntem River, W of Nyabessan, herb on rocks, stem flattened, creeping, N02 ${ }^{\circ} 24^{\prime}$ E10²2', 1 Dec. 1992.

Etymology. Named for Dr Gaston Achoundong, former head of the IRADNational Herbarium of Cameroon (YA), Secretary-General of AETFAT and noted specialist in Rinorea and co-collector of the type specimen.

Distribution - Cameroon, Memve'ele Falls, Ntem River; c. $395 \mathrm{~m}$ altitude.

Habitat \& Ecology - Along the Ntem River, where the river breaks into multiple channels and goes over an escarpment in multiple waterfalls at Memv'ele, flowering as the water level recedes in the dry season.

Conservation - Known only from the type locality at the Memve'ele Falls on the Ntem River, site of the Memve'ele Hydropower project. Financed by China Exim Bank, and constructed by Sinohydro for the Ministry of Power and Water Resources Cameroon, this is designed to have a $200 \mathrm{MW}$ capacity from a reservoir of 19 million $\mathrm{m}^{3}$ resulting from an earthfill dam $20 \mathrm{~m}$ high built across the top of the falls, diverting water from the falls through a turbine house (https://www.esi-africa. com/cameroon-and-sinohydro-partner-for-the-memve-elehydropower-station-project/ accessed 15 Feb. 2017). This project is expected to have highly negative effects on the survival of $I$. achoundongii since the dam will 'direct the flow of the river away from the multiple waterfalls ... This dam will disrupt the hydrology of the site by destroying many waterfalls and flooding or filling the rocky reach of the river above the falls". (Schenk et al. 2015 in describing I. achoundongii). These authors continued "our new species fits the IUCN criteria for Critically Endangered and could soon become extinct because of the dam construction and operation".

Schenk et al. (2015) also cite an earlier conservation assessment of another Podostemaceae species at the same site: "In the IUCN (2012) Endangered listing for Inversodicraea annithomae [the Cameroon material is now I. tchoutoi] known only from the type locality in Gabon and from the Chutes de Memve'ele, Jean-Paul Ghogue wrote: The major threat to this species in Cameroon is the dam construction planned in the only site locality of this species, the Ntem Waterfalls at Memve'ele near Nyabizon, 60 km east of Campo". 
Since 1 . achoundongii is only known from a single location, with an estimated $\mathrm{AOO}$ of $1 \mathrm{~km}^{2}$ and with threats as cited above, using IUCN (2012), we here assess its conservation status as CR B1+2ab(iii), that is Critically Endangered, confirming the assessment of Schenk et al. (2015). The species is not listed on www.iucnredlist.org.

Note - Inversodicraea achoundongii is notable in the genus for its: 1) small stature: plants are usually $<1 \mathrm{~cm}$ tall and can flower at only $5 \mathrm{~mm}$ tall (Schenk et al. 2015: f. 1); and 2) the primarily deltoid (equilaterally triangular) scale-leaves which are not imbricate, but only thinly scattered on the stems.

\section{Inversodicraea pepehabai Cheek}

Inversodicraea pepehabai Cheek in Cheek \& Haba (2016a) 3. - Type: Pepe M. Haba 292 (holotype HNG; isotypes K, P), Guinea-Conakry, GuineéForestère, Seredu, Mt Ziama, N8²1'25.8" W9¹8'30.7", fl., fr., 8 Feb. 2010.

Etymology. Named for the collector of the only known specimen, Pepe Haba of N'zerekore, one of the most expert field botanists in Guinea, cofounder of the environmental NGO Guinée-Biodiversité.

\section{Distribution - Republic of Guinea (Guinea-Conakry).}

Habitat \& Ecology — Rapids in submontane evergreen forest; c. $600 \mathrm{~m}$ a.s.l. altitude.

Conservation - Inversodicraea pepehabai was assessed in Cheek \& Haba (2016a) as Endangered under Criterion D, since less than 250 individuals are estimated to have been observed at the single location known (EN D1). The AOO is assessed as $1 \mathrm{~km}^{2}$. Currently there are no obvious threats to this species. But there is a risk that former activities within the Ziama Foret Classe are resumed. These activities are tea and quinine plantations, and timber extraction. Where any of these to happen then increased surface run-off can be expected. This would raise levels of nutrients and silt in the watercourse in which I. pepehabai is found. In turn this would increase algal growth that would compete with, and (due to increased silt levels), reduce establishment of new plants of the species. It is to be hoped that additional records of this species will be found at further sites, lowering its conservation assessment.

Additional specimens. GuInEA-Conakry, Guineé-Forestère, Seredu, Mt Ziama, N8²1'25.8" W9¹8'30.7", fl., fr., 8 Feb. 2010, Pepe Haba 292 (holotype HNG; isotypes $\mathrm{K}, \mathrm{P}$ ).

Notes - Inversodicraea pepehabai is unusual among African Podostemaceae being found in the rapids of a submontane forest area. Other species with this ecology are Saxicolella amicorum J.B.Hall (Hall 1971; pers. obs. Cheek 1995), Ledermanniella letouzeyi C.Cusset (Cusset 1987, Cheek et al. 2004), L. onanae Cheek (Cheek 2003, Cheek et al. 2004), and L. pollardiana Cheek \& Ameka (Cheek \& Ameka 2008). Most other species of the genus occur in rapids of lowland forest or woodland habits.

The affinities of $I$. pepehabai are probably with other West African species of the genus which have slender, usually lobed, scale-leaves. At first sight $I$. pepehabai appears very similar to the relatively common and widespread $I$. ledermannii, but the scale-leaves in that species are consistently, deeply and equally 3-lobed, and cover most of the stem, being \pm appressed, not patent. The scale-leaves of $I$. pygmaea ( $L$. taylori) are also similar, but are also consistently 3-lobed resembling I. ledermannii excepting that the central lobe is always longer than the laterals, and again, the stems are short (1-2 cm long) and completely covered in scale-leaves. In I. mortonii the scaleleaves are needle-like, and completely lacking lobes. Most similar to $I$. adamesii, in the irregularly lobed (lobes 1,2 , or absent) scale-leaves which cover $<50 \%$ of the stem. Distinct in the scale-leaves being patent (not \pm appressed), the flowers with 1 stamen (not 2), the fruits 8-ribbed (not 6).
Inversodicraea pepehabai is one of several plant species unique to the Ziama Massif inside the Ziama Man \& Biosphere reserve. It is likely to be proposed in the future as an 'Important Plant Area' for Guinea (see Darbyshire, continuously updated). Several other new species have recently been discovered at this location in Ziama including Gymnosiphon samoritourei Cheek (Cheek \& Van der Burgt 2010) and Allophylus samoritourei Cheek (Cheek \& Haba 2016b).

\section{Inversodicraea feika Cheek, sp. nov. - Fig. 2, 3}

Differs from all other species of Inversodicraea which have scale-leaves dense on the spathellae-bearing spur shoots and sparse or absent on the main shoot, in that the ovary and fruit are strongly laterally flattened and not cylindrical. Most similar to Inversodicraea adamesii, e.g., in fruit having only 6 longitudinal ribs, but differing in that c. $90 \%$ of the scale-leaves are entire (not $90 \% 3$-lobed). Unique in the genus is that the styles are narrowly triangular in side view (Fig. 2f), resembling those of Dicraeanthus, not subulate, filiform or botuliform. - Type: Feika 146 (holotype K; isotypes BR, EA, FBC n.v., G, K, LISC, MA, MO, P, PRE, S, SL, US, WAG, Z), Sierra Leone, Western Area, Port Loko District, Port Loko, N845'29.0" W1247'10.0", near bridge across Port Loko river in Port Loko town, 10 m alt., fl., fr., 17 Dec. 2010.

Etymology. Named in honour of Mr. Abdulai Feika of the National Herbarium of Sierra Leone (SL) at Njala University. He is the collector of the only two known specimens of the species.

Perennial herb, long stems streaming in the water, $15-80 \mathrm{~cm}$ long, terete, $1.5-2(-3) \mathrm{mm}$ diam along most of their length, internodes $1.5-3 \mathrm{~cm}$ long in the proximal $1 / 2-3 / 4$, decreasing to $0.7-1.5 \mathrm{~cm}$ long in the distal portions, sometimes with $1-3$ principal branches. Root horizontal, terete, stolon-like, $0.6-1 \mathrm{~mm}$ diam, extending at least $5 \mathrm{~cm}$ long or more, internodes $2.5-7$ $\mathrm{mm}$ long, nodes bearing opposite leaves which subtend fertile, leaflet-clad spur shoots (Fig. 2c-d) which can develop into erect highly branched candelabra-like stems c. $5 \mathrm{~cm}$ tall (Fig. 2a (upper portion) and Fig. 2b) and/or long sparingly branched stems. Lateral stems $0.8-7 \mathrm{~cm}$ long, usually regularly spaced along the principal stems, arising 1-4 $\mathrm{mm}$ below (and later than) the long ribbon-like leaves, scale-leaves and flowers at the nodes. Leaves ribbon-like, (0.7-)3-5(-7) cm long, 0.6-1.5 mm wide, 1-4-dichotomously branched, strongly dorsiventrally flattened (ribbon-like), apices acute. Scale-leaves more or less confined to the short spur shoots, 13-23 scale-leaves per shoot, spirally inserted; acicular, ascending, $0.2-0.3(-0.4)$ by 0.15 by 0.1 $\mathrm{mm}$, apex acute to obtuse, entire, or rarely (1-2 in 10) with a lateral lobe c. $0.05 \mathrm{~mm}$ long. Spathellum cylindrical, substipitate $3.5-4(-4.2)$ by (1-)1.2-1.3(-1.4) $\mathrm{mm}$ apex rounded-obtuse, dehiscing irregularly at apex. Pedicel $7-8.5 \mathrm{~mm}$ long, $0.5 \mathrm{~mm}$ diam at base, narrowing towards the apex. Tepals 2, opposite stamen, narrowly oblanceolate, $(0.9-) 1.3-1.5$ by $0.1 \mathrm{~mm}$, minutely papillate. Androecium of 2 stamens, nearly as long or slightly longer than the ovary; united filaments $1-1.3 \mathrm{~mm}$ long (3 mm in fruit), free filaments $1.3-1.5 \mathrm{~mm}$ long $(2 \mathrm{~mm}$ in fruit); anthers 4 -celled, oblong, $0.9-1$ by $0.5 \mathrm{~mm}$. Pollen in dyads, $70-75$ by $37-42 \mu \mathrm{m}$, the two grains each subspheroidal. Gynoecium with gynophore 1-1.1 $\mathrm{mm}$ long (2.5 $\mathrm{mm}$ in fruit). Ovary unilocular, oblong-elliptic in side view, 1.3-1.8(-2.2) by $0.6-0.8$ by $0.4-0.5 \mathrm{~mm}$. Styles erect, narrowly triangular, 1.2 $\mathrm{mm}$ long, $0.2 \mathrm{~mm}$ wide at base. Fruit oblong-elliptic, strongly laterally flattened, 2.5 by 0.9 by $0.6 \mathrm{~mm}$, with 6 longitudinal ribs, ribs pronounced, each projecting 1.0-1.5 mm; sutures not pronounced, dehiscing by a single suture. Seeds oblongellipsoid $0.2-0.25$ by $0.1-0.12 \mathrm{~mm}$.

Distribution - Sierra Leone, Port Loko.

Habitat \& Ecology - On rocks in rapids of river, with I. ledermannii, in the evergreen forest zone; $10 \mathrm{~m}$ altitude.

Conservation - Known only from one location within Port Loko town limits, at two sites on the river locally known as the Gbankasoka. The AOO is estimated as $1 \mathrm{~km}^{2}$. Threats observed 


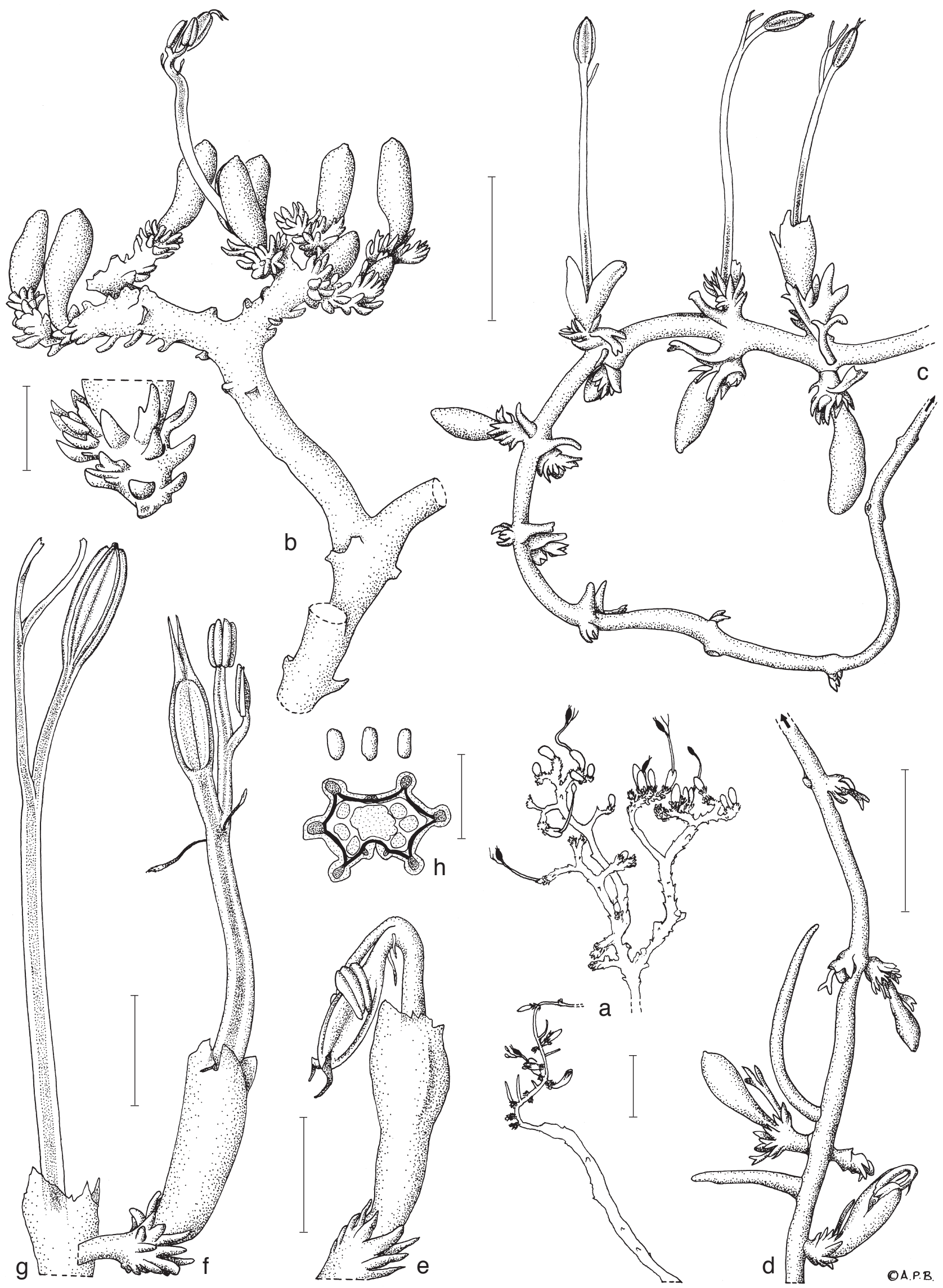

Fig. 2 Inversodicraea feika Cheek. a. Habit in dry season; a1. branched, erect flowering plant, leaves fallen; a2. subcylindrical root developing from old stem; b1. detail of a1; b2. detail of spur shoot with scale-leaves; c. stolon-like root upper surface, showing opposite, distichous short leaves and endogenous branching; d. stolon-like root, lower surface, with two undifferentiated endogenous root branches (detail from a2); e. spur shoot with spathellum just after dehiscence; f. spur shoot, with flower at anthesis; g. fruit; $\mathrm{h}$. fruit in transverse section, three seeds in lateral view above (all from Feika $78 B$, K). $-\mathrm{Scale}$ bars: a $=1 \mathrm{~cm}$; $\mathrm{b}-\mathrm{d}=5 \mathrm{~mm} ; \mathrm{e}-\mathrm{g}=2 \mathrm{~mm}$; $\mathrm{h}$, (small inset) $=0.5 \mathrm{~mm}$. - Drawn by Andrew Brown. 

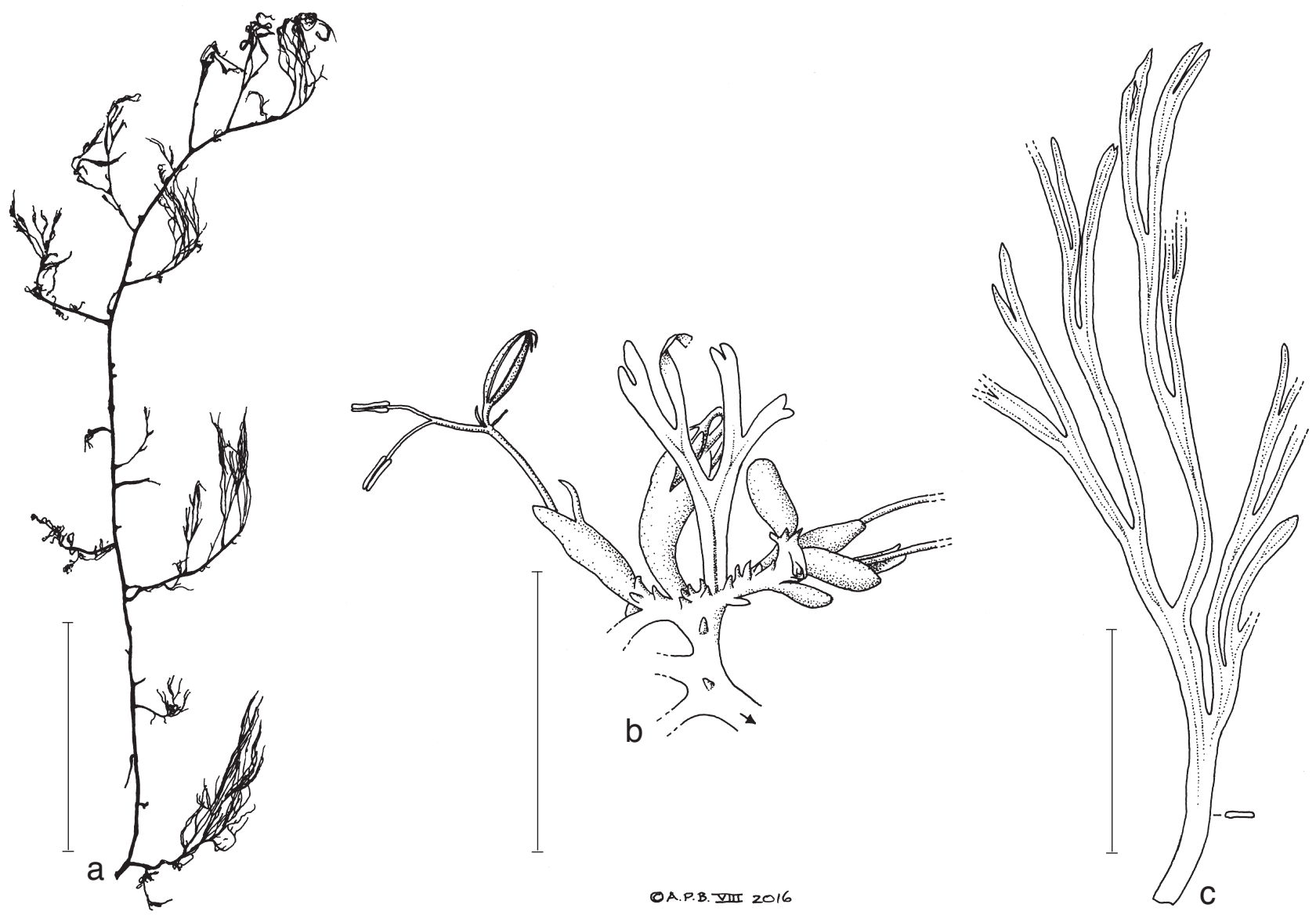

Fig. 3 Inversodicraea feika Cheek. a. Habit, end wet season, long stem with branches, dichotomous leaves attached; b. detail of spur shoot with scale-leaves, spathellae and one dichotomous leaf; c. flattened, ribbon-like, dichotomous leaf (transverse section at lower right) (all from Feika 146 , K). - Scale bars: a = 10 $\mathrm{cm} ; \mathrm{b}=1 \mathrm{~cm} ; \mathrm{c}=2 \mathrm{~cm}$. - Drawn by Andrew Brown.

are pollution of the habitat from clothes washing (Ben Pollard pers. comm. to M. Cheek 2010) and bridge construction for iron ore transport (Lebbie pers. comm.). Further, a micro-hydroelectric project is planned for the site. Therefore, I. feika is here assessed as Critically Endangered, CR B2 ab(iii). Port Loko in the most populous district in Sierra Leone after Freetown's Western Areas District.

Additional specimens. SierRa Leone, Western Area, Port Loko District, Port Loko, N8 ${ }^{\circ} 45^{\prime} 29.0^{\prime \prime} \mathrm{W} 12^{\circ} 47^{\prime} 10.0^{\prime \prime}$, near bridge across Port Loko river in Port Loko town, 10 m alt., fl., fr., 17 Dec. 2010, Feika 146 (holotype K; isotypes BR, EA, FBC n.v., G, K, LISC, MA, MO, P, PRE, S, SL, US, WAG, Z); ibid., fl., fr., Mar. 2010, Feika 78B (K, SL n.v.).

Notes - Inversodicraea feika is one of the most completely known species of the genus thanks to the two collections of Feika made by Mr. Feika and his associate collectors Ben Pollard, Sue Frisby, and Xander van der Burgt.

It has been collected in the reproductive state in mid dry season (March, Feika 78B), when it produced spathellae from the stolons and short ( $5 \mathrm{~cm}$ tall) candelabra-like stems, and in December at the end of the wet season when long streaming stems and leaves were present as well as spathellae (Feika 146).

Material of this taxon first came to light in March 2010 (Feika 78) as a result of a baseline botanical study for the transport corridor for the Tonkolili iron ore mine, at that time operated by African Minerals Limited (AML) but now owned by Shandong Iron \& Steel. Feika 78 was found to be a mixed collection of I. ledermannii (formerly Ledermanniella ledermannii) segregated as Feika 78A, with a second undescribed species (segregated as Feika $78 B$ ) which was recognised as new to science and drawn up for publication (Fig. 2). Since the 6 ribbed ovary and fruit (resulting from inverted flowers) was strongly laterally compressed, the generic attribution of Macropodiella Engl. was initially made, following the prevailing classification of Cusset (e.g., Cusset 1987). However, in the interim increasingly better sampled molecular studies (Moline et al. 2007, Thiv et al. 2009, Schenk et al. 2015) have thrown doubt on some of the generic limits of Cusset's classification (1978, 1983, 1984, 1987). So far as Macropodiella and Ledermanniella are concerned, morphological data also give cause to doubt the generic delimitation (Cheek \& Ameka 2016). It is now clear that Feika 78B, due to the flattened, sometimes lobed, scale-like scale-leaves that it presents, is unambiguously best placed in the newly resurrected genus Inversodicraea (Cheek \& Haba 2016a). Since the completion of Fig. 2, extensive additional material (17 sheets) was collected from the same site in December 2010 (Feika 146) which shows additional character of the taxon and which has been selected as type of the species and illustrated as Fig. 3.

\section{Inversodicraea ebo Cheek, sp. nov. - Fig. 4}

Differs from I. cristata Engl. in having wings extending from the distal parts the non-commissural ribs of the ovary (vs wings absent), in having the base of the stem with either scattered, non-pectinate scales or (next to the substrate) naked, with a corky epidermis (in I. cristata the stem is covered in pectinate scales to the base), and in the leaflet lobes being nearly parallelsided with an abruptly rounded apex (not narrowly triangular with an acute apex). - Type: van der Burgt 1716 (holotype YA; isotype K), Cameroon, Littoral Region, Yabassi, Ebo proposed National Park, near Locndeng, Ebo River, fl., 7 Dec. 2013.

Etymology. Named for the Ebo River and Ebo proposed National Park to which this species is unique according to the evidence available.

Rheophytic, probably perennial herb. Basal thalloid portion thick, orbicular, $1.5-1.6 \mathrm{~cm}$ diam, margin shallowly lobed, upper surface entirely lacking leaves but with a single tree or shrub-like stem arising from the centre (Fig. 4a). Stem erect, robust, $0.6-0.8 \mathrm{~cm}$ diam at base, unbranched for $(0.6-) 1-2 \mathrm{~cm}$, 


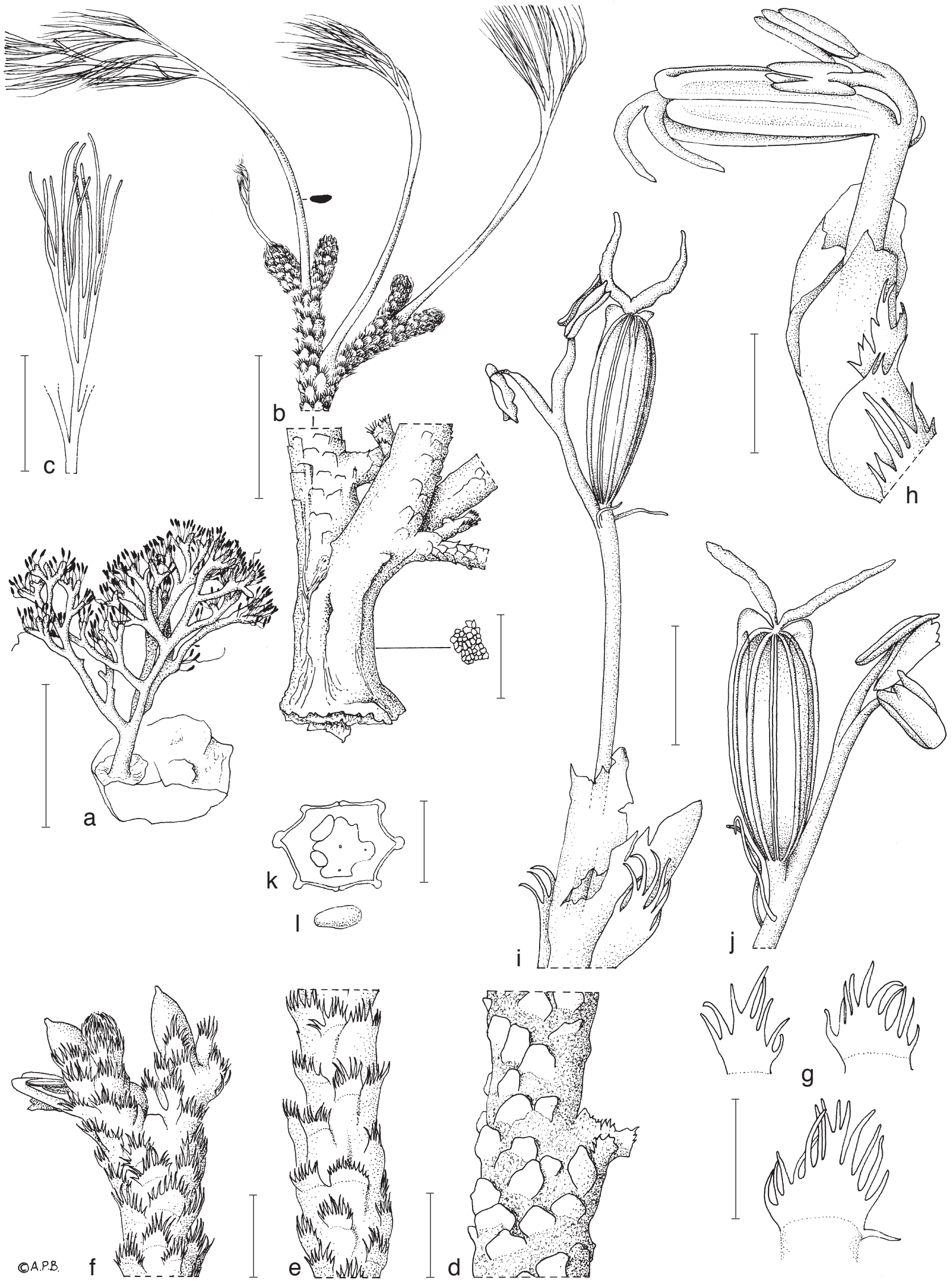

Fig. 4 Inversodicraea ebo Cheek. a. Habit, whole plant in flower and fruit, showing disc-like thalloid portion anchored to rock; b. details of non-flowering plant, showing (below) base of stem (inset detail of corky epidermal cells) and non-pectinate scale-leaves on branches; (above) terminal origin of leaves (inset transverse section of leaf base); c. detail of dichotomously branched leaves; d. portion of lower stem showing scale-leaves lacking pectinate margins; e. stem from midpoint of plant showing pectinate scale-leaves covering c. $50 \%$ of surface; f. stem apex with spathellae buds and scale-leaves covering $80-100 \%$ of surface; g. three scale-leaves showing variation (dotted basal line indicates insertion on stem); h. flower emerging from spathellum, before anthesis; i. flower detail at anthesis, note the distally united wings of the ovary ribs; j. whole flower at anthesis, including spathellum; $\mathrm{k}$. fertilised ovary, transverse section, slightly laterally flattened; I. seed, side view (all from Xander van der Burgt $1716, \mathrm{~K}$ ). - Scale bars: $\mathrm{a}=5 \mathrm{~cm} ; \mathrm{b}=1 \mathrm{~cm} ; \mathrm{c}-\mathrm{f}=2 \mathrm{~mm} ; \mathrm{g}-\mathrm{j}=1 \mathrm{~mm} ; \mathrm{k}-\mathrm{I}=500$ $\mu \mathrm{m}$. - Drawn by Andrew Brown. 
then dividing into 2-3 subequal branches, those branches themselves dividing every $1-2 \mathrm{~cm}$ along their length, and the resultant branches further, until c. 50 stem apices are present; stem apices $1.5-2 \mathrm{~mm}$ diam, $80-100 \%$ clothed in pectinate scale-leaves (Fig. 4f); stems equidistant between apex and base becoming wider, 1.8-2.2 $\mathrm{mm}$ diam, 40-50\% covered by scale-leaves; stems $1-3 \mathrm{~cm}$ above the base $2.2-3 \mathrm{~mm}$ diam, the scale-leaves lacking their pectinate margin; stem bases, at junction with thalloid area, lacking scale-leaves, surface with grey-brown corky isodiametric cells $0.003 \mathrm{~mm}$ diam (Fig. 4b, inset detail). Scale-leaves appressed, flattened, orbicular-oblong in outline (0.75-) $0.85-1.2(-1.3)$ by (0.4-) $0.5-$ $1.2 \mathrm{~mm}$, the proximal, entire part crescent-shaped, its distal margin extending into 8-14 subequal, subparallel, linear divisions $0.3-0.5$ by $0.05(-0.1) \mathrm{mm}$, apices acute, the shorter divisions marginal, leaflet attachment curved, 0.3-0.75 mm long. (Fig. 4g). Leaves arising terminally on stems, stems then dividing into two, so that the leaves appear to arise in the axils of dichotomous stem forks (Fig. 4b); proximal 1/2-2/3 $(1.7-2.1 \mathrm{~cm})$ of leaf entire, ribbon-like in transverse section c. 1.5 by $0.5 \mathrm{~mm}$; distal $1 / 2-1 / 3$ branching dichotomously up to 5-7 times, with $27-70$ terminal filiform segments c. $1.5-2$ by $0.05 \mathrm{~mm}$, stipules absent (Fig. 4c). Spathellae single or in pairs at stem apex (Fig. 4f); buds cylindric-ellipsoid c. 2 by $1 \mathrm{~mm}$, mucro $0.25 \mathrm{~mm}$ long, apex truncate-rounded, base sessile, concealed by scale-leaves; opening by an irregular tear into two parts, pedicel c. $3.5 \mathrm{~mm}$ long at anthesis. Tepals filiform, $0.5-1.1 \mathrm{~mm}$ long inserted opposite to the androecium 0.1-0.3 $\mathrm{mm}$ below the insertion of the gynophore. Androecium slightly longer than the ovary $(2.2-2.5 \mathrm{~mm}$ long), stamens two, free filaments $0.8-0.9 \mathrm{~mm}$ long, anthers $0.65-0.7$ by $0.3-0.4 \mathrm{~mm}$. Pollen in monads, prolate, $54-69$ by $38 \mu \mathrm{m}$. Ovary ellipsoidoblong, slightly laterally flattened, the median and submedian nerves of each valve extended distally into rounded-triangular, fin-like wings, $0.15-0.2$ by $0.2-0.35 \mathrm{~mm}$; united to each other distally; gynophore $0.15-0.3 \mathrm{~mm}$ long; stigmas irregularly swollen, subcylindrical, tapering gradually to apex, 0.9 by 0.15 $\mathrm{mm}$. Capsule hexagonal in transverse section, 0.8 by $0.6 \mathrm{~mm}$ (Fig. 4k) with 6 major and 2 minor (commissural) longitudinal, convex ribs (Fig. 4k). Seeds ellipsoid 0.3 by $0.15 \mathrm{~mm}$.

Distribution - Cameroon endemic, known only from the Ebo River near Locndeng in Littoral Region.

Habitat \& Ecology - Rheophyte on rocks in rapids of river.

Conservation - Known only from the type location in the Ebo proposed National Park to which this species is unique according to the evidence available. Threats include forest clearance for oil palm plantations, logging, and open cast iron ore mining, any of which would result in increased surface runoff and increased turbidity of the water which forms the habitat for this species. The AOO is estimated as $1 \mathrm{~km}^{2}$. Accordingly, I. ebo is here assessed as Critically Endangered, CR B2 ab(iii).

Notes - Inversodicrea ebo appears to have a close affinity to both $I$. cristata and I. tchoutoi. All three species resemble miniature, highly branched, bonsai trees. All three have the broad, convex apex of the leaflet divided often into ten or more subequal regular divisions. While in the last species these divisions are equilaterally triangular, those in the two former are long and slender. However, I. cristata and $I$. ebo are separated by the characters given in the diagnosis. The distally winged ovary ribs of $I$. ebo are unusual in the genus, otherwise occurring only in I. warmingiana, I. eladii, and I. congolana.

The robust construction of $l$. ebo suggests that it is a long-lived, perennial species. It is conjectured that the scale-leaves near the base of the stem lack pectinate margins due to age, and that the corky base of the stem is an adaptation to guard against desiccation in the drier season when the plants are exposed above waterlevel.

\section{Inversodicraea xanderi Cheek, sp. nov. - Fig. 5}

With Inversodicraea harrisii C.Cusset, I. congolana Hauman and I. tenax (C.H.Wright) Engl., unusual in the genus in having projections from the abaxial surface of the leaflet (not flat, as in all other species). Most similar to $I$. tenax in having multiple projections, but differing from all three species in having 5 or more marginal teeth, not tridentate, and in the strongly dimorphic scale-leaves, those on the stem distant from the spathellae having (6-)7-9 teeth and lacking abaxial projections (not tridentate with abaxial projections). - Type: van der Burgt 1940 (holotype K; isotypes P, YA n.v., Z), Cameroon, South Region, Campo, Campo-Ma'an National Park, North of the road Campo to Ma'an, N2 ${ }^{\circ} 2^{\prime} 57.1^{\prime \prime}$ E10 $10^{\circ} 21.8^{\prime \prime}$, old fr., alt. $230 \mathrm{~m}$, 4 Mar. 2016.

Etymology. Named for Xander van der Burgt (1958-) Dutch botanist, formerly of the Herbarium Vadense, Wageningen, now of the Royal Botanic Garden, Kew, specialist in field surveys in tropical Africa, and especially in the Leguminosae-Caesalpinoideae. Collector of the only known specimen of Inversodicraea xanderi.

Erect annual herb, $1.5-3 \mathrm{~cm}$ tall including fruits (Fig. 5b). Root horizontal, dorsiventrally flattened (ribbon-like), adhering to substrate, $1.5-2 \mathrm{~mm}$ wide, lateral branches arising at $50-60^{\circ}$ from the main axis, at intervals of $6-8 \mathrm{~mm}$; internodes $1-5$ $\mathrm{mm}$ long (Fig. 5a). Stems erect, terete, leaflet-clad, 0.1-1.6 $\mathrm{cm}$ long, 0.4-0.6 mm diam, 0.7-0.8 $\mathrm{mm}$ wide including scaleleaves. Leaves not seen, probably caducous, dichotomously branched. Scale-leaves completely covering the stems, appressed, dimorphic: a) normal scale-leaves (Fig. 5e) 1-1.6 by $0.7 \mathrm{~mm}$, distal part hemi-orbicular, digitately (6-)7-9-toothed, teeth marginal, subequal, narrowly conical, length : breadth c. 2-3 : 1, length 0.1-0.2 mm; b) distal scale-leaves (Fig. 5d), subtending spathellae, $1-1.1$ by $0.7 \mathrm{~mm}$, free, distal part oblong to triangular, marginal teeth $5-6$, each (0.1-) $0.2-0.3 \mathrm{~mm}$ long, abaxial surface with $(4-) 5-7(-10)$ conical projections, each $0.05-0.3 \mathrm{~mm}$ long. Spathellae single, terminal or subterminal. Pedicel 12-14 mm long in fruit. Gynophore with distal 0.9-1.1 $\mathrm{mm}$ decorticating, leaving only the 6 vascular strands (Fig $5 \mathrm{c} 2$ ). Tepals, androecium and ovary unrecorded. Fruit narrowly cylindric-ellipsoid, c. 2.5 by $0.4-0.5 \mathrm{~mm}$, with 6 longitudinal ribs, ribs conspicuous, subequal (Fig. $5 c 2$ ); sutures not pronounced (commissural ribs absent), dehiscing by two sutures, valves not caducous. Seeds unrecorded.

Distribution - Cameroon, South Region, Campo.

Habitat \& Ecology — On rocks in stream 0-50 cm above water level near Campo town in primary evergreen forest; $230 \mathrm{~m}$ altitude.

Conservation - Known only from one location on the river near Campo inside the Campo-Ma'an National Park currently one of the most protected areas in Cameroon. The AOO is estimated as $1 \mathrm{~km}^{2}$. It is here assessed as NT in view of the small AOO, since no threats are currently known. Should threats be evidenced, this species should be reassessed as Critically Endangered.

Additional specimens. CAmERoon, South Region, Campo, Campo-Ma'an National Park, North of the road Campo to Ma'an, N2 ${ }^{\circ} 20^{\prime} 57.1^{\prime \prime} \mathrm{E} 10^{\circ} 13^{\prime} 21.8^{\prime \prime}$, old fr., alt. 230 m, 4 Mar. 2016, van der Burgt 1940 (holotype K; isotypes P, YA n.v., Z).

Notes - Decortication of the outer surface of the developing fruit exposes the longitudinal ribs of Inversodicraea according to Thiv et al. (2009). In I. xanderi this same process appears to extend from the base of the fruit to the gynophore, leaving the first connected to the pedicel only by the six vascular strands that comprise the fruit ribs (Fig. 5c2). The annual nature of I. xanderi is confirmed by the type material, all of which appears to have been dead before it was collected.

The abaxial leaflet projections are conjectured to aid the protection of the developing spathellae from predation by grazing animals. 
Table 1 Characters separating Inversodicraea cristata and Inversodicraea xanderi (data for I. cristata from Cusset (1983)).

\begin{tabular}{lll}
\hline & I. cristata & I. xanderi \\
\hline Root width & $1 \mathrm{~mm}$ & $1.5-2 \mathrm{~mm}$ \\
Fruiting pedicel length & $9-10 \mathrm{~mm}$ & $12-14 \mathrm{~mm}$ \\
Distal portion of gynophore decorticated & No & Yes \\
Scale-leaves dimorphic & No & Yes \\
No. marginal teeth (normal scale-leaves) & $5-7(-10)$ & $(6-) 7-9$ \\
Scale-leaves with abaxial projections & No & Yes \\
Fruit dimensions $(\mathrm{mm})$ & $1.8-2$ by $0.8-1$ & 2.5 by $0.4-0.5$ \\
\hline
\end{tabular}

Inversodicraea xanderi is known from a post-mature, fruiting collection. In the shape and toothing of the majority of its scaleleaves it is similar to I. cristata, which also occurs in Cameroon. It is likely that the two have an affinity. The points of separation between the two species are detailed in Table 1. The abaxial projections of the spathellae-subtending scale-leaves of $I$. xanderi are rarely encountered in Africa, being seen in only three other species, all of which differ from $I$. xanderi in numerous points (see above, under 'diagnosis'). Flowering material of this taxon is desirable.

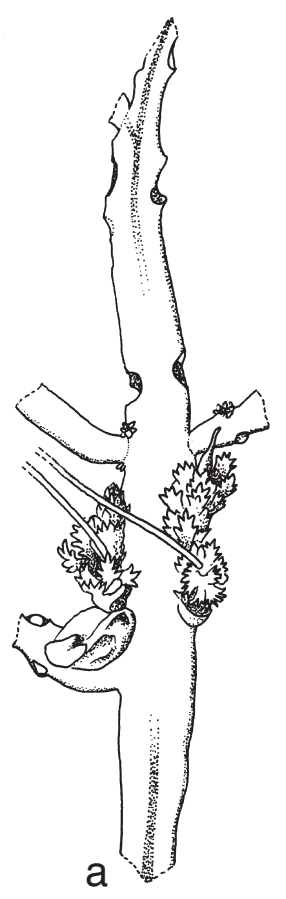

O A.P.B. VIII 2016
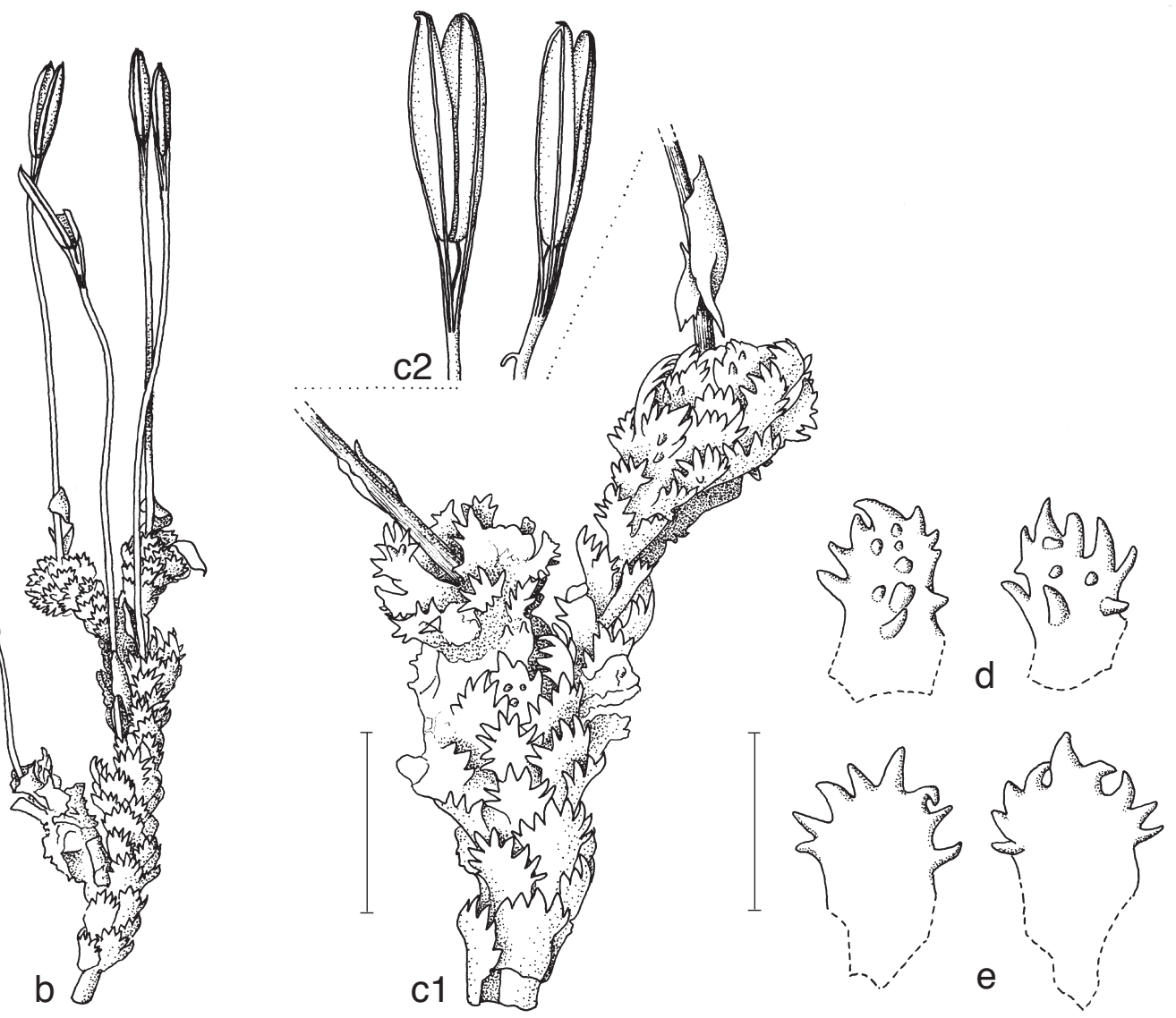

Fig. 5 Inversodicraea xanderi Cheek. a. Root viewed from above, showing erect leaflet covered stems and pedicel bases; b. erect, sparingly branched stem with fruits; c1. detail of fruiting stems, with c2 detail of dehisced fruits; d. detail of spathellae-subtending scale-leaves; e. detail of normal scale-leaves (all from Xander van der Burgt 1940, K). - Scale bars: $a-b=1 \mathrm{~cm} ; \mathrm{c} 1-\mathrm{c} 2=2 \mathrm{~mm}$; $\mathrm{d}-\mathrm{e}=1 \mathrm{~mm}$. - Drawn by Andrew Brown.

\section{Inversodicraea cussetiana (Cheek \& Ameka) Cheek,} comb. nov.

Basionym. Macropodiella cussetiana Cheek \& Ameka (2016) 2. - Type: J. de Koning 5232 (holotype K; isotypes UCJ n.v. WAG), Côte d'Ivoire, Sassandra River, near Louga, N503'02.53" E6¹2'32.55", fl., fr., 25 Jan. 1975.

Etymology. Named in honour of Colette Cusset of $\mathrm{P}$, to whom all working on African Podostemaceae owe a great debt for establishing the taxonomic framework on which all current research is based.

Distribution - Côte d'Ivoire, Sassandra River (type collection only).

Habitat \& Ecology - On rocks of rapids in river in evergreen forest zone; $17 \mathrm{~m}$ altitude.

Conservation - Rapids and waterfalls are often favoured sites for placing hydroelectric projects, which threaten Podostemaceae species present at such sites by construction of dams, turbine houses, canals, and other connected infrastructure on their habitat, by the permanent submergence and loss of aerated water in areas flooded by the dam, and by the change to the natural hydrological regime in areas downstream of the dam.
The only known locality for Macropodiella cussetiana is on the Sassandra river about $20 \mathrm{~km} \mathrm{~N}$ of the coastal town of Sassandra. Further upriver, about $92 \mathrm{~km} \mathrm{~N}$ of the type locality of M. cussetiana, is the town of Soubre, and the Naoua Falls where a new hydroelectric scheme managed by Sinohydro is planned (http://www.hydroworld.com/articles/2014/01/alstom-winscontract-to-outfit-ivory-coast-s-soubre-hydropower-project.html downloaded 26 June 2014). This project threatens the only known global locality for Macropodiella taylorii (J.J.de Wilde \& Guillaumet) C.Cusset whereat multiple specimens have been made (Cusset 1978). In June 2014 interest was being shown in developing hydropower sites downriver of Soubre, which threatens Macropodiella cussetiana (http://www.hydroworld. com/articles/2014/06/ivory-coast-seeks-hydropower-sitestudies-below-270-mw-soubre-hydro-project.html downloaded 26 June 2014). Since the latest Google Earth imagery for the area dates from 4 Oct. 2013 (downloaded 12 Jan. 2016) the exact location and state of development of the project cannot be viewed remotely through this means.

The only known site for this species lies just inside the 'Parc Naturel de Gaoulou' as demarcated on Google Earth (viewed 
13 Jan. 2016). This area appears to be less heavily impacted by development than adjoining areas, although it still contains villages and palm oil plantations and is far from pristine.

Since there is a single location, with an $\mathrm{EOO}$ and $\mathrm{AOO}$ estimated (using current IUCN guidance for aquatic plants) of $1 \mathrm{~km}^{2}$, and with the clear threat of a hydroelectric scheme being constructed in the vicinity of the only known location, we here assess I. cussetiana as Critically Endangered, CR B1+B2 ab(iii). This assessment follows that of Cheek \& Ameka (2016). Should the project referred to go ahead, it is possible that this species will become extinct, given the evidence available at present.

Notes - Inversodicraea cussetiana is transferred here from Macropodiella since it has been established through molecular means (e.g., Thiv et al. 2009) that the possession of scaleleaves (indicating Inversodicraea) has primacy over whether or not the ovary and fruit are laterally flattened (flattened ovaryfruits previously defining Macropodiella, e.g., Cusset 1983). Inversodicraea cussetiana may have a close affinity with I. feika of Sierra Leone since that species also has laterally flattened ovaries. However, this character may have arisen independently several times (see Cheek \& Ameka 2016). Within Macropodiella we had placed I. cussetiana with M. garrettii and M. macrothyrsa (G.Taylor) Cusset, however, these last two species appear to lack the scale-leaves which indicate Inversodicraea so are not similarly transferred in this paper. However, it is possible that they may simply have lost scale-leaves entirely. If this can be shown as probable with molecular phylogenetic methods then consideration should be giving to transferring these two species also.

This is the only known species of the genus known for Cote D'Ivoire apart from a single record of I. ledermannii (Aké Assi 2002).

\section{Inversodicraea tchoutoi Cheek, sp. nov. - Fig. 6}

Similar to Inversodicraea ebo Cheek in the perennial, subshrubby, erect, highly branched habit; differing in that the ovaries and fruits lack apical wings, usually have 3 (not 2 ) stigmas, the leaflet margins have $(5-) 9-11(-16)$ equilaterally triangular teeth, not 8-14 linear divisions. - Type: Tchouto Peguy with Elad Maurice, Nnangah Austin 3378 (holotype K; isotypes KRI n.v., SCA n.v., WAG, YA n.v.), Cameroon, South Province (now Region), Campo Ma'an Area, Memve'ele waterfalls, N2²4' E10²1'48", alt. 360 m, fl., fr., 17 Jan. 2002.

Ledermaniella cf. cristata sensu Ghogue (2011: 95).

Etymology. Named for Dr. Peguy Gildas Tchouto, botanist and forester, formerly of the Mount Cameroon Project, later Professor at Mbalamayo Forestry School, now GTZ Biodiversity Adviser, Programme for the Sustainable Management of Natural Resources, Mount Cameroon.

Perennial, erect, subshrubby rheophytic herb, 4(-20) cm tall, repeatedly pseudodichotomously branched in the upper part forming flat-topped crowns $4.8-9 \mathrm{~cm}$ diam, with 40-90 ultimate branches. Root horizontal, narrowly ribbon-like (dorsiventrally flattened), adhering to substrate, $0.6-1.3 \mathrm{~mm}$ wide, lateral branches arising at (45-)70-90 from the main axis, at intervals of $1.2-5 \mathrm{~mm}$. Stems arising at margin of root, opposite, sparse, developing a circular holdfast base to 4-12 $\mathrm{mm}$ diam, stem unbranched, terete, for 2-15 mm, 4-5 mm diam, surface wrinkled. Scale-leaves closely appressed and completely covering the upper part of the main axis and the ultimate stem branches, drying green, completely flat, papery in texture. Scale-leaves produced when underwater (when leaves are also present) are denser, with a low length : breadth ratio. Scale-leaves produced when plants emerged (leaves absent) are longer and less congested. Emerged scale-leaves are oblong-spatulate, $1.35-2(-2.5)$ by $(0.4-) 0.5-0.8(-1.3)$ $\mathrm{mm}$, distal portion obtusely rounded in outline, and wider than the $0.3-0.5 \mathrm{~mm}$ wide proximal $\mathrm{c}$. half which has entire, concave sides, the margin of distal portion with (5-)9-11(-16) \pm regular equilaterally triangular subequal teeth, teeth dentate, $0.03-0.08(-0.1) \mathrm{mm}$ long. Scale-leaves of the mid and lower part of the main axis with $5 \%$ cover, semicircular, lacking welldeveloped lobes or teeth drying black, 0.8 by $0.9 \mathrm{~mm}$, apex rounded. Leaves 2.2-8.3(-10) cm long, 5 times (or more) dichotomously branched, arising singly at the stem dichotomies; stipules absent; petiole flattened, at base, $0.5 \mathrm{~mm}$ wide, 0.9-3.5 $\mathrm{cm}$ long, narrowly ribbon-like, $0.5-0.75 \mathrm{~mm}$ wide, repeatedly dividing, gradually tapering to a point at apices. Spathellae arising at branch dichotomies, single, obovoid 1.1-1.3 mm long including the basal stipe c. 0.4 by $0.12 \mathrm{~mm}$, partly concealed by the scale-leaves, mucro $0.1 \mathrm{~mm}$ long; the obovoid central portion $0.7-0.8$ by $0.3-0.4 \mathrm{~mm}$, dehiscing in c. 4 deep, irregular lobes, margins becoming involute. Flower pink (Tchouto 3378), erect. Pedicel $14-15 \mathrm{~mm}$. Tepals 2, subulate, erect, $0.9-1 \mathrm{~mm}$ long. Stamens 2 , shorter than gynoecium; united portion of filaments $1.5-1.7 \mathrm{~mm}$ long, free portions $1-1.1 \mathrm{~mm}$ long, the branches diverging at c. $90^{\circ}$. Anthers white, $1-1.1$ by $0.35-0.4$ $\mathrm{mm}$ pollen in monads, $0.03-0.038 \mathrm{~mm}$ diam. Gynophore 1.6 $\mathrm{mm}$, dilating gradually at apex into the ovary. Ovary unilocular, fusiform $1.8-2.3$ by $0.5(-0.7) \mathrm{mm}$, apex rounded-truncate. Stigmas 3 , subulate, $0.65 \mathrm{~mm}$ long, gradually tapering to the apex, papillate, united at the base, spreading. Longitudinal ribs 6 , equally prominent and spaced, the two commissural ribs much more weakly developed, with a central line of dehiscence. Fruit dehiscing into 2 equal, persistent valves, containing c. 40 seeds. Seeds ovoid, 0.25 by $0.07 \mathrm{~mm}$, laterally flattened.

Distribution - Cameroon, South Region, Ntem River, known only from the Memv'ele Falls.

Habitat \& Ecology - Waterfalls in the evergreen forest zone, with two wet and dry seasons. 'Accroché en tapis sur rochers recouverts d'eau torrenteuse et cascadant. Abondant'. (Letouzey 10299); 350-450 m altitude. The species grows mixed with Ledermanniella bifurcata (e.g., Letouzey 15334).

Conservation - Since $I$. tchoutoi is only known from a single location, with an estimated $\mathrm{AOO}$ of $1 \mathrm{~km}^{2}$ and with threats as cited under $I$. achoundongii and I. ntemensis, we here assess its conservation status as Critically Endangered, CR B1+2ab(iii).

Additional specimens. CAmeroon, South Region, Campo Ma'an Area, Boucle du Ntem, Around Meyas Ntem, N2 ${ }^{\circ} 20^{\prime} 80^{\prime \prime}$ E10 ${ }^{\circ} 35^{\prime} 16^{\prime \prime}$, fr., alt. 480 m, 16 Feb. 2001, Tchouto 3170 (K, KRI n.v., SCA n.v., WAG); ibid., Memve'ele waterfalls, N2 $24^{\prime}$ E10²1'48", fr., alt. 360 m, 17 Jan. 2002, Tchouto 3376 (K, KRI n.v., SCA n.v., WAG, YA); ibid., 3377 (K, KRI n.v., SCA n.v., WAG, YA n.v.); ibid., 3378 (K, KRI n.v., SCA n.v., WAG, YA n.v.); ibid., Chutes du Ntem ou de Memve'ele prés Nyabessan (60 km E de Campo), st., 8 Apr. 1970, Letouzey 10299 (P00179253 image; P00179252 image); ibid., Chutes du Ntem prés de sa derivation sur la Bongola, 40 km ESE Campo, fl., 10 Dec. 1979, Letouzey 153399 (P00179268 image; P00179269 image; YA 3 sheets); ibid., fr., 21 Jan. 2016, Sene 1-15 (K, YA); ibid., 21 Jan. 2016, Sene 1-16 (K, YA).

Notes - Using Cusset $(1983,1987)$, I. tchoutoi would key out as $I$. cristata. The species can be separated using the features in Table 2. Podostemologists working in Cameroon (Koi et al. 2012, Schenk et al. 2015) appear to have referred to $I$. tchoutoi as I. (Ledermanniella) annithomae as discussed below and under the last species. Inversodicraea annithomae differs in having unbranched, floating, flexible stems which have short inflorescence shoots opposed to leaves at nodes, and constant internode lengths. It appears to be confined to the Ogouué River of Gabon.

The presence of three stigmas in I. tchoutoi otherwise only occurs within the genus in I. ntemensis, which, however, appears not to be particularly similar to $I$. tchoutoi. Horizontal gene transfer can be postulated, since they occur at the same site and both appear globally restricted to the Ntem River.

First collected in 1970 when sterile (Letouzey 10299), Cusset initially determined this specimen as I. cristata Engl. in June 


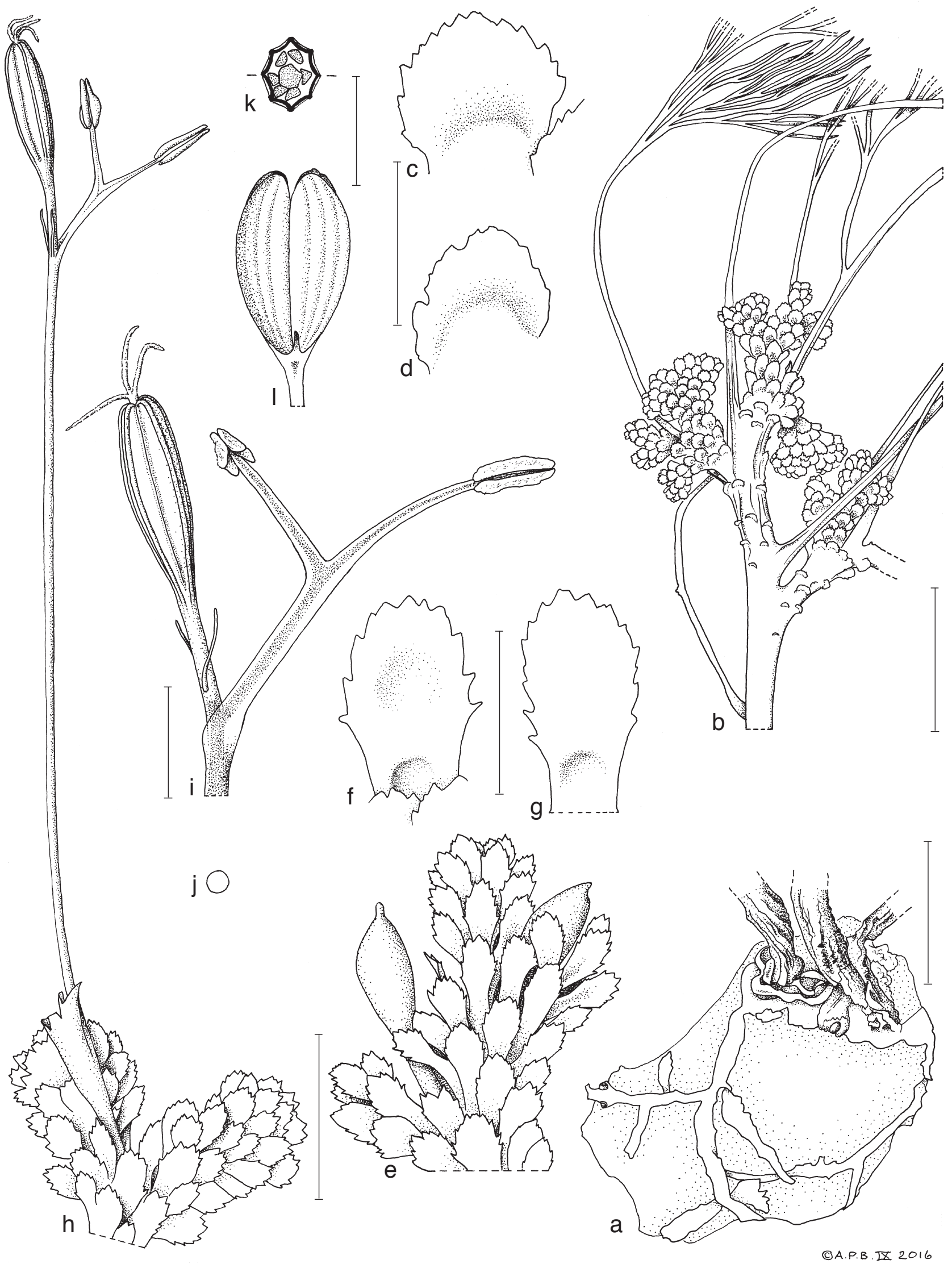

Fig. 6 Inversodicraea tchoutoi Cheek. a. Branched root, with base of perennial erect stems; b. distal portion of branching stems showing scale-leaves and leaves; c. detail of distal leaflet from b; d. detail of older leaflet from b; e. distal part of stem with unopened spathellae; f. detail of upper part of leaflet from e (base concealed by scale-leaves below); g. entire leaflet from e, including base; h. stem apices with flower at anthesis; i. detail of flower excluding pedicel, note the three styles; j. monad pollen grain; k. ovary, transverse section; I. fruit after dehiscence, inner surface of valves (all from Tchouto 3377 , K). - Scale bars: $\mathrm{a}-\mathrm{b}=1 \mathrm{~cm} ; \mathrm{c}-\mathrm{g}, \mathrm{i}, \mathrm{k}-\mathrm{l}=1 \mathrm{~mm} ; \mathrm{h}=3 \mathrm{~mm}$. - Drawn by Andrew Brown. 
Table 2 Characters separating Inversodicraea tchoutoi and Inversodicraea cristata (data for I. cristata from Cusset (1983)).

\begin{tabular}{lll}
\hline & I. cristata & I. tchoutoi \\
\hline Leaflet shape (branches) & $\begin{array}{l}\text { Broadly elliptic to } \\
\text { obovate }\end{array}$ & Oblong-spatulate \\
Leaflet dimensions & $\begin{array}{l}1.2-1.5 \mathrm{by} \\
0.9-1.2 \mathrm{~mm}\end{array}$ & $\begin{array}{l}(1.35-) 1.7-2(-2.5) \mathrm{by} \\
(0.4-) 0.65-0.8(-1.3) \mathrm{mm}\end{array}$ \\
No. of teeth per leaflet & $5-7(-10)$ & $(5-) 9-11(-16)$ \\
Length of leaflet teeth & $0.2-0.3 \mathrm{~mm}$ & $0.05-0.08(-0.1) \mathrm{mm}$ \\
Length of post-anthetic & $5-10 \mathrm{~mm}$ & $14-15 \mathrm{~mm}$ \\
pedicel & & \\
Fruit shape and width & Ellipsoid, 0.8-1 mm & Fusiform, 0.5-0.7 mm \\
Stem base scale-leaves & Tridentate & Subentire, rounded \\
\hline
\end{tabular}

1971, which is logical in view of the habit and the multiple dissections of the leaflet edge, albeit that these dissections are shallower and more triangular than those of that species. Consciousness of this may have led Cusset (1983) to redetermine the specimen as paratype of $I$. annithomae which can have similar shallow multiple dissections. Cusset may have attributed the absence in Letouzey 10299 of the long, flexible flowing stems of $I$. annithomae as well as the great differences in inflorescence arrangement, to the juvenile, sterile state of Letouzey 10299.

Letouzey 15339 identified by Cusset in 1980, and published as paratype of Ledermanniella boumiensis (Cusset 1983) is I. tchoutoi. There is no evidence that $I$. boumiensis occurs outside Gabon.

From Letouzey's (10299) field notes and from the notes of Tchouto's copious specimens, it appears that this species grows in colonies that cover rocks, like a green pile carpet, flowering mid December to mid January (leaves present), with fruits in mid February (leaves absent) and becoming sterile by mid April.

\section{Inversodicraea eladii Cheek, sp. nov. — Fig. 7}

Inversodicraea eladii (Fig. 7) has its closest affinity with two species, I. bosii (see Table 3 for differences), which occurs at the same locality, and I. congolana which occurs at the other side of the Congo basin. The first lacks the distinctive apical 2-winged ovary-fruit of $I$. eladii, and also differs in the scale-leaves being mostly ( $>90 \%$ ) ovate; the proximal half of the stems being naked of scale-leaves; the leaves being 1-dichotomous. In I. eladii the scale-leaves are mainly triangular or with 1-2 small lateral triangular lobes (apart from subulate scale-leaves near the spathellae) and the stems have a c. $5 \%$ covering of scale-leaves; the leaves are many-times dichotomously branched. Inversodicraea congolana closely resembles $I$. eladii in the apically 2-winged ovary and fruits. However, the fruits of $I$. eladii are 6-ribbed, not 8-ribbed as in I. congolana. Further, the leaves are only dichotomous (not 4-5-times dichotomous), the habit only $0.5-1.5 \mathrm{~cm}$ tall, not $6-10 \mathrm{~cm}$ tall. - Type: Elad Maurice with Tchouto Peguy 1485A (holotype K; isotypes KRI, WAG, YA), Cameroon, South Region, Camp Ma'an area, Lobe, Lobe Waterfalls in Grand Batanga area at the edge of the sea, N2 ${ }^{\circ} 52^{\prime} 57^{\prime \prime} \mathrm{E9}^{\circ} 53^{\prime} 50^{\prime \prime}$, fl., alt 5 m, 30 Nov. 2001.

Table 3 Characters separating Inversodicraea bosii and Inversodicraea eladii (data for I. bosii taken from Cusset (1983)).

\begin{tabular}{lll}
\hline & I. bosii & I. eladii \\
\hline $\begin{array}{l}\text { Leaflet shape } \\
\text { (below spathellae) }\end{array}$ & $\begin{array}{l}\text { Ovate, entire (rarely } \\
\text { with 1-2 lateral lobes), } \\
0.5-0.6 \text { by } 0.2 \mathrm{~mm}\end{array}$ & $\begin{array}{l}\text { Subulate (near spathellae), } \\
\text { narrowly triangular or slightly } \\
\text { 1-2-lobed, 1-1.25 by } \\
0.28-0.4 \mathrm{~mm}\end{array}$ \\
Leaves & 1-dichotomous & $\begin{array}{l}4-5 \times \text { dichotomous } \\
\text { Ovary-fruit }\end{array}$ \\
& Lacking wings; 8-ribbed & $\begin{array}{l}\text { With 2 conspicuous tri- } \\
\text { angular apical wings; } \\
\text { 6-ribbed }\end{array}$ \\
Main axes & Lacking scale-leaves & $\begin{array}{l}\text { Scale-leaves present, } \\
\text { regularly placed, c. 5-10 \% } \\
\text { cover entire to shallowly trifid }\end{array}$
\end{tabular}

Etymology. Named for the late Maurice Elad, tree-spotter and botanical collector, collector of the type and only known specimen of Inversodicraea eladii, known to the first author since 1992.

Rheophytic herb, probably annual, root not recorded; stems erect, free-standing, highly branched, $6-10 \mathrm{~cm}$ tall, terete, 1-1.9 $\mathrm{mm}$ diam at base, each stem arising from rock with 30-50 ultimate branches. Scale-leaves on main stem and branches (below the distal 3-6 mm) wrinkled, naked apart from c. $5 \%$ cover of narrowly to equilaterally triangular (rarely slightly lobed), partly spreading scale-leaves $0.25-0.5$ by $0.2-0.4$ $\mathrm{mm}$. Distal 3-6 $\mathrm{mm} \pm$ completely covered in scale-leaves, scale-leaves narrowly triangular, $1-1.25$ by $0.28-0.4 \mathrm{~mm}$, apex acute, margin entire, at about $10 \%$ of scale-leaves with a deep lateral division or bifurcation, sometimes with two shallow, unequal lateral triangular divisions each $0.02-0.15 \mathrm{~mm}$ long, which one greatly smaller than the central lobe, these 2-lobed scale-leaves most common in the interstitial zone between the densely covered distil $3-6 \mathrm{~mm}$ of the branches, and the $5 \%$ sparsely covered lower branches and main stems. Leaves $1.6-5 \mathrm{~cm}$ long, arising laterally, 4-5-times dichotomously branched, rarely a single, scale-leaf-like lobe near bases of younger leaves, triangular, $0.25-0.1 \mathrm{~mm}$, placed on the petiole margin up to $0.7 \mathrm{~mm}$ from the base; petiole $0.9-3.2 \mathrm{~cm}$ long dorsiventrally flattened, $0.4-1.5 \mathrm{~mm}$ wide (widest in the older leaves produced on the main axis); blade ribbon-like (dorsiventrally flattened), $0.5-0.8 \mathrm{~mm}$ wide, tapering gradually to the acute apices. Spathellae inserted at stem dichotomies, single, obovoid-cylindric $2.5-3.2$ by $1 \mathrm{~mm}$, apex rounded, base concealed among scale-leaves, cylindric; opening irregularly into 3-5-deep, integral lobes. Pedicel 8.5-9(-10) mm long. Tepals 2, linear, 0.75-0.8(-1.1) $\mathrm{mm}$ long, inserted at new base of androecium. Androecium exceeding gynoecium, c. $5 \mathrm{~mm}$ long, anthers 2; united filaments 1-2 mm long, free filaments diverging by c. $20-45^{\circ}, 2-3 \mathrm{~mm}$ long. Anthers subtriangular, $1-1.25$ by $0.3 \mathrm{~mm}$. Pollen in dyads, long axis $0.05 \mathrm{~mm}$ long. Gynophore $0.3-0.5 \mathrm{~mm}$ long, dilating gradually to base of ovary. Ovary unilocular, narrowly cylindrical-ellipsoid 2.5-2.7 by $0.6-0.75 \mathrm{~mm}$. Styles 2 , erect, narrowly subulate, $0.75-1.1$ by $0.05 \mathrm{~mm}$ wide at base, sometimes united in the proximal $0.2 \mathrm{~mm}$. Longitudinal ribs 8 , subequal in spacing and development, the two submedial ribs on each side united by a triangular or rounded membranous protrusion, making the ovary apex 2-winged; commissural ribs each with a sutural groove. Fruit dehiscing by two valves, not caducous. Seeds not recorded.

Distribution - Cameroon, South Region, Lobé river at Lobé Falls.

Habitat \& Ecology - Rheophyte on rocks in waterfall near the sea, in evergreen forest zone; $5 \mathrm{~m}$ altitude.

Conservation - Inversodicraea eladii is known from a single location, the Lobé Falls, at which we assess its AOO (and so its EOO) as $1 \mathrm{~km}^{2}$ using the IUCN-preferred cells of that size. Here, as is the case for $I$. bosii, similarly restricted to this location, it is threatened by trampling from the many tourists that visit what in Cameroon is a major tourist attraction (Cheek in Onana \& Cheek 2011, Ghogue 2011). Therefore the species is here assessed as Critically Endangered, CR B2 ab(iii).

Notes - Ovary wings are rare in the genus. Otherwise they are only known in I. ebo, I. congolana, and I. warmingiana, the last with a triangular wing from the apex of all six longitudinal ribs. Only in $I$. eladii and $I$. ebo of Cameroon do the wings appear to connect more than one rib on each valve of the ovary. Distal (and also lateral) ovary wings are highly developed in the genus Winklerella Engl. In fact this appears to be the only character supporting recognition of that genus, leading us to question whether this distinction is merited or not. 


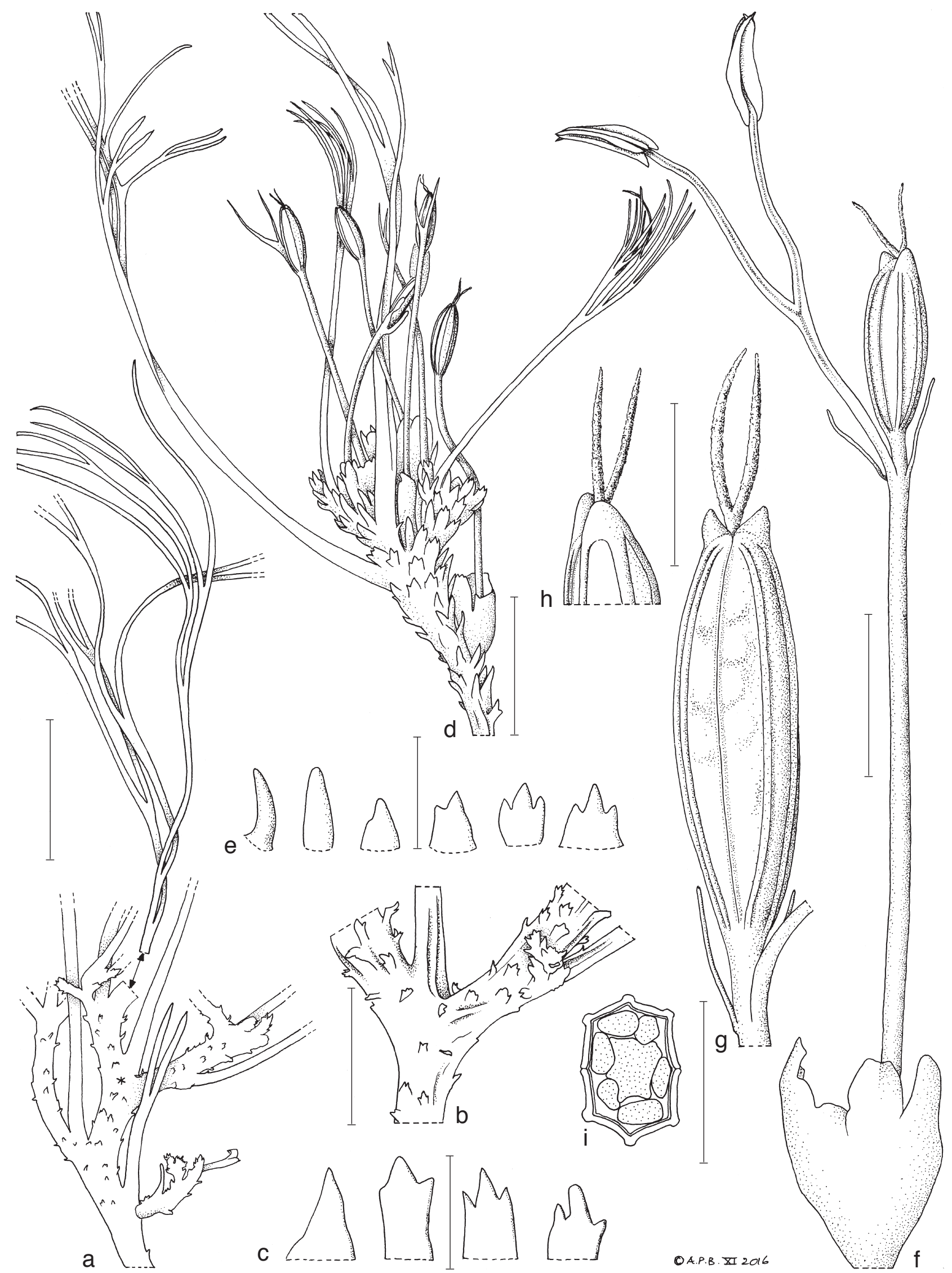

Fig. 7 Inversodicraea eladii Cheek. a. Habit, showing stem basal branching, note origin of leaves from pseudo-dichotomies; b. detail from a (point marked *) pseudo-dichotomous node; c. detail of scale-leaves from base and central parts of stems shown in a; d. stem apex with leaves and flowers; e. scale-leaves from d, note the subulate scale-leaves subtending the spathellum at left; f. flower; g. gynoecium and tepals; $h$. ovary apex with stigmas; i. transverse section of ovary (all from Elad et al. 1485, K). - Scale bars: $a=1 \mathrm{~cm} ; \mathrm{b}, \mathrm{d}=5 \mathrm{~mm} ; \mathrm{c}, \mathrm{e}, \mathrm{g}-\mathrm{i}=1 \mathrm{~mm} ; \mathrm{f}=2 \mathrm{~mm}$. - Drawn by Andrew Brown. 
Near the base of three young leaves, a single lobe, similar to a scale-leaf, was noted. Initially, these were taken to be stipular lobes, but since each leaf has only one such lobe and not a pair, and since they are not present on most leaves, this has been ruled out.

Hybridisation - The type collection Elad 1485A was mixed (Kew sheet) with an equal amount of sterile I. ledermannii (Elad 1485) which superficially looked very similar, but which was identified by its scale-leaves being broadest in the distal half, and equally, and deeply acutely trilobed. That $I$. eladii was in flower while the I. ledermannii had not yet developed spathellae suggests that the first flowers in advance of the second, which suggests reproductive separation of the two species. Nevertheless, specimens from this same locality (Elad 1482, 1484) appear to be intermediate between these two species in leaflet shape, the scale-leaves being long and slender, as in $I$. eladii, but with c. $50 \%$ divided at the apex into three subequal, but not spreading, lobes. These plants may represent hybrids between the two species.

\section{Inversodicraea liberia Cheek, sp. nov. - Fig. 8}

Differs from Inversodicraea pepehabai in the scale-leaves being arranged in c. 3 ranks (not 5), the basal half of the scale-leaves being appressed and sheathing the stem (not patent, with the leaflet flat), the fruit 1-1.2 $\mathrm{mm}$ long (not 3-4 mm long). - Type: Robert M. Warner 87A (holotype K), Liberia, on rocks in water, 1942-43.

Etymology. Named (noun in apposition) for the country of Liberia.

Probably annual rheophytic herb, root not recorded, $1.5 \mathrm{~cm}$ tall. Stems erect, 2-4-branched, terete, $0.5 \mathrm{~mm}$ diam at base, main stem $40-50 \%$ covered by scale-leaves arranged in c. 3 ranks, stem apex more densely covered (Fig. 8). Scale-leaves $0.75(-1.5)$ by $(0.25-) 0.4-0.6 \mathrm{~mm}$ with proximal half appressed

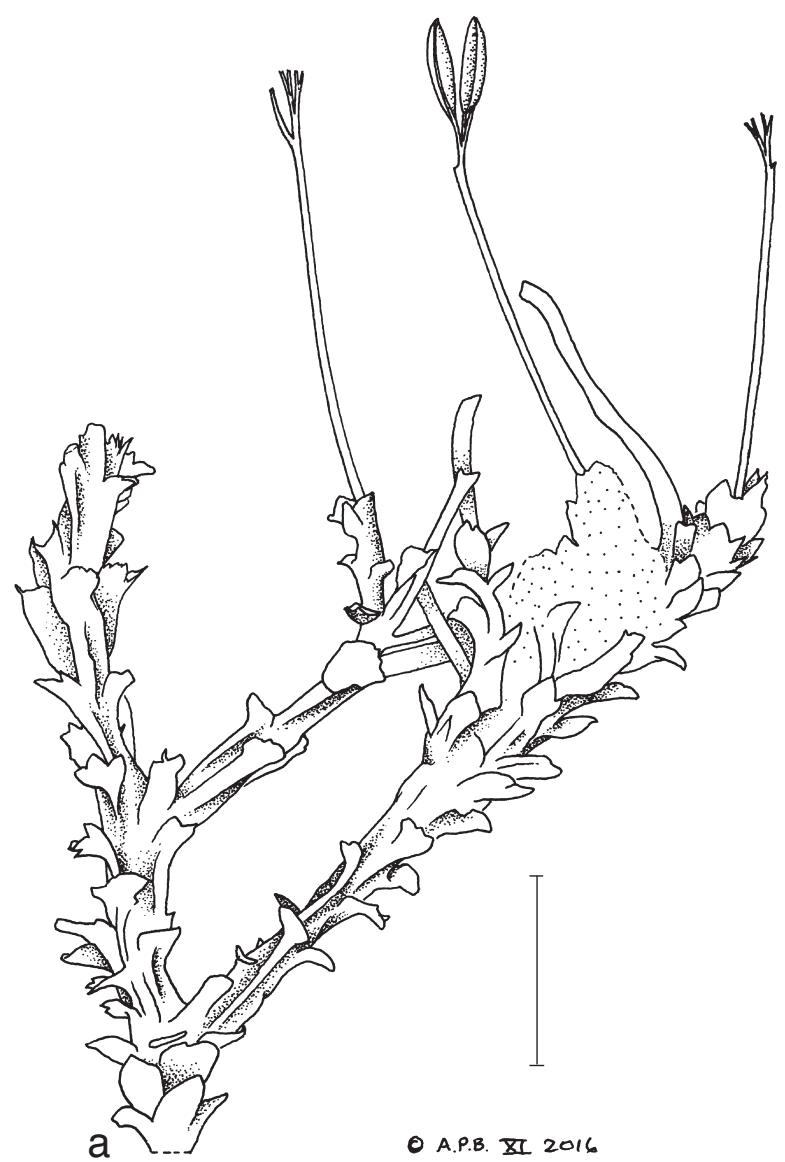

and sheathing the stem, the lateral margins folded towards the stem; distal portion dilating, the apex broadly rounded, sometimes with a lateral triangular lobe c. 0.1 by $0.1 \mathrm{~mm}$. Leaves c. $4 \mathrm{~mm}$ long, lateral insertion, once dichotomous, petiole $3 \mathrm{~mm}$ long, dorsiventrally flattened, $0.2-0.3 \mathrm{~mm}$ wide at base, blade ribbon-like, c. $0.1 \mathrm{~mm}$ wide, $0.6 \mathrm{~mm}$ long, apices rounded. Spathellum in bud, unrecorded, at dehiscence subglobose, 0.75 by $0.6 \mathrm{~mm}$. Pedicel $2.5-3(-3.7) \mathrm{mm}$ long. Tepals and androecium unrecorded. Gynophore $0.25 \mathrm{~mm}$ long. Ovary and styles unrecorded. Fruit ellipsoid, brown, $1-1.1$ by $0.5-0.6$ $\mathrm{mm}$, apex rounded, base gradually decurrent into gynophore, decorticating to expose 6 vascular strands; longitudinal ribs 6 , equal, the commissural ribs only weakly developed with a central longitudinal groove (suture); dehiscing into two equal non-caducous valves, dehiscence extending into gynophore. Seeds 1.1 by $0.75 \mathrm{~mm}$.

Distribution - Only known from the type specimen in Liberia.

Habitat \& Ecology - Unknown, but probably waterfalls in the lowland rainforest zone.

Conservation - Since the location for I. liberia, and therefore threats, are unknown, we assess the species here as NT, indicating that since it is known from a single location, probably with only a few hundred plants, it is vulnerable to loss from hydroelectric projects and other habitat modification events such as silt input into rivers from run-off due to logging and/or from artisanal mining.

Notes - Warner $87(\mathrm{~K})$ is a mixture of two species, determined by Cusset in 1974 as Macropodiella garrettii (C.H.Wright) C.Cusset (here designated as Warner 87) and Ledermanniella cf. gabonensis C.Cusset (here designated as Warner $87 A$ ). It is $87 A$, L. cf. gabonensis, that is here described as I. liberia. Inversodicraea gabonensis and I. liberia are two geographically distant yet both share a similar habit, and membranous

Fig. 8 Inversodicraea liberia Cheek. a. Habit, fruiting plant; b. detail of stem below spathellum, * indicates young scale-leaves; c. post-anthetic flower showing remains of 2 anthers and spathellum; $d$. fruit, dehiscence incipient, note absence of commissural ribs; e. dehiscing fruit with seeds; f. transverse section of fruit; g. seed (all from R.M. Warner $87 A, \mathrm{~K}$ ). - Scale bars: $\mathrm{a}=2 \mathrm{~mm} ; \mathrm{b}-\mathrm{g}=1 \mathrm{~mm}$. - Drawn by Andrew Brown. 
Table 4 Characters separating Inversodicraea liberia and Inversodicraea pepehabai.

\begin{tabular}{|c|c|c|}
\hline & I. liberia & I. pepehabai \\
\hline No. leaflet files per stem & c. 3 & C. 5 \\
\hline $\begin{array}{l}\text { Leaflet posture } \\
\text { (below stem apex) }\end{array}$ & $\begin{array}{l}\text { Proximal half appressed, } \\
\text { sheathing stem, distal } \\
\text { part spreading }\end{array}$ & $\begin{array}{l}\text { Patent or spreading } \\
\text { from base (never ap- } \\
\text { pressed or sheathing } \\
\text { in basal part) }\end{array}$ \\
\hline $\begin{array}{l}\text { Leaflet apex broadly } \\
\text { rounded? }\end{array}$ & $\begin{array}{l}\text { Apex broadly rounded } \\
\text { in }>50 \% \text { of leaves, } \\
\text { rarely acute or obtuse }\end{array}$ & $\begin{array}{l}\text { Apex obtuse or acute, } \\
\text { never rounded }\end{array}$ \\
\hline Leaf branching & $1 \times$ dichotomous & $3-4 \times$ dichotomous \\
\hline $\begin{array}{l}\text { Fruit-ovary length } \\
\text { (undehisced) }\end{array}$ & $1-1.2 \mathrm{~mm}$ & $3-4 \mathrm{~mm}$ \\
\hline
\end{tabular}

scale-leaves. However, I. gabonensis has scale-leaves tapering at the apex and which are appressed to the stem, covering it completely in the distal half, while in I. liberia the scale-leaves cover only $40-50 \%$ of the stem and the distal part of the scaleleaves are often spreading, > $50 \%$ having a broadly rounded apex. Moreover, in I. liberia the fruits are only c. $1 \mathrm{~mm}$ long vs c. $2 \mathrm{~mm}$ in I. gabonensis.

Inversodicraea liberia is possibly more closely related to I. pepehabai of neighbouring Guinea than to I. gabonensis since they are geographically close. Both species share more or less spreading or patent scale-leaves, which occurs nowhere else in those Inversodicraea species with membranous scale-leaves which lack regular margin ornamentation or lobes. The two species can be distinguished using the characters shown in Table 4.

Although Warner 87 was seen by Cusset in 1974, she did not refer to it in her revision of Ledermanniella subg. Phyllosoma (Cusset 1983).

Warner 87 (with $87 A$ ), comprising the two species of Podostemaceae referred to, appears to be the first and so far only record of any member of that family from Liberia (apart from Tristicha trifaria, mentioned in Taylor 1954). Undoubtedly many more species of Podostemaceae, including those new to science, await discovery in Liberia since neighbouring countries east and west each have several endemic species of the family.

The absence of any previous published record to Warner 87 is probably partly due to the incomplete nature of both species that it contains. Regarding I. liberia, the material is both meagre, and lacks flowers. The localisation is also poor since only 'Liberia' is given as the source. Better and more complete material which would allow a full description of the species, would be welcomed. The species was described to encourage interest in this distinct species and to guard against the possibility that it might not be found again.

\section{EXCLUDED SPECIES}

The following names published as Inversodicraea are excluded from that genus:

\section{Africa}

Inversodicraea aloides Engl. = Ledermanniella aloides (Engl.) C.Cusset

I. batangensis (Engl.) Engl. = Ledermanniella batangensis (Engl.) C.Cusset

I. bifurcata Engl. = Ledermanniella bifurcata (Engl.) C.Cusset

I. bowlingii J.B.Hall = Ledermanniella bowlingii (J.B.Hall) C.Cusset

I. garrettii C.H.Wright = Macropodiella garrettii (C.H.Wright) C.Cusset

I. keayi G. Taylor = Ledermanniella keayi (G. Taylor) C.Cusset
I. laciniata Engl. = Saxicolella laciniata (Engl.) C.Cusset

I. letestui Pellegr. = Ledermanniella letestui (Pellegr.) C.Cusset

I. macrothyrsa G. Taylor = Macropodiella macrothyrsa (G.Taylor) C.Cusset

I. minima Engl. = Ledermanniella bifurcata (Engl.) C.Cusset

I. monanthera H.Hess = Sphaerothylax abyssinica (Wedd.) Warm.

I. musciformis $\mathrm{G}$. Taylor = Ledermanniella musciformis (G.Taylor) C.Cusset

I. pellucida Engl. = Macropodiella pellucida (Engl.) C.Cusset

I. pusilla (Warm.) Engl. = Ledermanniella pusilla (Warm.) C.Cusset

I. schlechteri (Engl.) Engl. = Ledermanniella schlechteri (Engl.) C.Cusset

I. tenuifolia Engl. = Ledermanniella tenuifolia (Engl.) C.Cusset

I. tenuissima Hauman = Ledermanniella schlechteri (Engl.) C.Cusset

I. thalloidea Engl. = Ledermanniella thalloidea (Engl.) C.Cusset

I. variabilis $\mathrm{G}$. Taylor $=$ Ledermanniella variabilis (G. Taylor) C.Cusset

I. zenkeri Engl. = Ledermanniella bifurcata (Engl.) C.Cusset

\section{Madagascar}

Inversodicraea bemarivensis (Tul.) H.Perrier = Endocaulos mangorense (H.Perrier) C.Cusset

I. imbricata (Tul.) H.Perrier = Paleodicraeia imbricata (Tul.) C.Cusset

I. isalensis (H.Perrier) H.Perrier = Thelethylax isalensis (H.Perrier) C.Cusset

I. manorensis (H.Perrier) H.Perrier = Endocaulos mangorense (H.Perrier) C.Cusset

I. minutiflora (Tul.) H.Perrier $=$ Thelethylax minutiflora (Tul.) C.Cusset

I. rubra (H.Perrier) H.Perrier = Sphaerothylax abyssinica (Wedd.) Warm.

Acknowledgements Fieldwork leading to the discovery of the new species reported in this paper was supported by Environmental Impact Assessment studies for the Tonkolili Iron Ore project (I. feika) and the Memv'ele Dam (I. tchoutoi, in part). The discovery of $I$. ebo and $I$. xanderi were due to surveys funded by the Bentham-Moxon Trust of RBG, Kew, while I. eladii and I. tchoutoi (in part) were found during doctoral studies by Dr Tchouto at the University of Wageningen, funded by the Dutch government. Inversodicraea liberia was discovered as a result of herbarium studies.

Professor Basile Camara and Dr Seydou Magassouba, respectively former and current Director General, Université de Gamal Abdel Nasser-Herbier National de Guinée, and Dr Jean Michel Onana and Dr Marie Florence Ngo Ngwe, respectively former and current Head of IRAD-National Herbarium of Cameroon, are thanked for arranging permits for the fieldwork that enabled the collection of some of the data presented in this paper, including some of the new species to science. They are also thanked for their support and collaboration. Drs Bethan Morgan and Ekwoge of the Ebo Forest project gave logistic support to the survey that discovered $I$. ebo. Janis Shillito is thanked for typing the manuscript. George Gosline assisted with access to electronic specimen data and made valuable comments on an early version of this paper. This paper was partly completed under the project Important Plant Areas in the Republic of Guinea supported by the Darwin Initiative of the Department of the Environment Food and Rural Affairs (DEFRA), UK government (project Ref. 23-002). Two anonymous reviewers are thanked for their constructive comments.

\section{REFERENCES}

Aké Assi L. 2002. Flore de la Côte D'Ivoire. II. Boissera 58: 49. Geneva. Baillon H. 1890. Observations sur quelques nouveaux types du Congo. Bulletin Mensuel de la Société Linnéenne de Paris 2: 876-878.

Baker JG, Wright CH. 1909. Podostemaceae. In: Thistleton-Dyer WT (ed), Flora of Tropical Africa VI section 1. Reeve, London.

Beentje H. 2005. Podostemaceae. Flora of Tropical East Africa. Balkema, The Netherlands. 
Cheek M. 2003. A new species of Ledermanniella (Podostemaceae) from western Cameroon. Kew Bulletin 58: 733-737. doi: http://dx.doi.org/ 10.2307/4111153.

Cheek M, Ameka G. 2008. Ledermanniella pollardiana sp. nov. (Podostemaceae) from western Cameroon. Nordic Journal of Botany 26: 214-217. doi: http://dx.doi.org/10.1111/j.1756-1051.2008.00162.x.

Cheek M, Ameka G. 2016. Macropodiella cussetiana (Podostemaceae) a new species from Côte d'Ivoire. Kew Bulletin 17: 2. doi: http://dx.doi. org/10.1007/S12225-016-9634-9.

Cheek M, Challen G, Lebbie A, et al. 2016. Discovering Karima (Euphorbiaceae): a new crotonoid genus from West Tropical Africa long hidden within Croton. PLOS ONE. doi: http://dx.doi.org/10.1371/journal.pone.0152110.

Cheek M, Gosline G, Mackinder B, et al. 2001. The phytogeography and Flora of Western Cameroon and the Cross River-Sanaga River interval. Systematics and Geography of Plants 71, 2: 1097-1100. doi: http://dx.doi. org/10.2307/3668742.

Cheek M, Haba P. 2016a. Inversodicraea Engl. resurrected and I. pepehabai sp. nov. (Podostemaceae), a submontane forest species from the Republic of Guinea. Kew Bulletin 71 (4) -55. doi: http://dx.doi.org/10.1007/s12225016-9673-2.

Cheek M, Haba P. 2016b. Spiny African Allophylus (Sapindaceae): a synopsis. Kew Bulletin 71: 57. doi: http://dx.doi.org/10.1007/s12225-016-9672-3.

Cheek M, Pollard BJ, Darbyshire I, et al. 2004. The plants of Kupe, Mwanenguba and the Bakossi Mountains, Cameroon: a conservation checklist. Royal Botanic Gardens, Kew, UK.

Cheek M, Poveda LL, Darbyshire I. 2015. Ledermanniella lunda sp. nov. (Podostemaceae) of Lunda Norte Angola. Kew Bulletin 70: 10. doi: http:// dx.doi.org/10.1007/S12225-015-9559-8.

Cheek M, Van der Burgt X. 2010. Gymnosiphon samoritoureanus (Burmanniaceae) a new species from Guinea, with new records of other achlorophyllous heteromycotrophs. Kew Bulletin 65, 1: 83-88. doi: http://dx.doi. org/10.1007/s12225-010-9180-9.

Cheek M, Van der Burgt X, Momoh J, et al. 2017. Ledermanniella yiben sp. nov. (Podostemaceae), Critically Endangered at the proposed Yiben Reservoir, Sierra Leone. Kew Bulletin 72: 31. doi: https://doi.org/10.1007/ s12225-017-9699-0.

Chevalier A. 1938. Podostémonacées. In: Flore Vivant de L'Afrique Occidentale Française 1: 289-298. Muséum Nationale d'Histoire Naturelle, Paris.

Cusset C. 1973. Contribution à l'étude des Podostemaceae. III. Le genre Stonesia. Bulletin du Museum National d'Histoire Naturelle, Paris, 4e sér, 6, sect. B, Adansonia 13: 307-312.

Cusset C. 1974. Contribution à l'étude des Podostemaceae. VI. Les genres Ledermanniella, Monandriella et Inversodicraea. Bulletin du Museum National d'Histoire Naturelle, Paris, 4e sér, 6, sect. B, Adansonia 14: 271-275.

Cusset C. 1978. Contribution à l'étude des Podostemaceae. V. Le genre Macropodiella Engl. Bulletin du Museum National d'Histoire Naturelle, Paris, 4e sér, 6, sect. B, Adansonia 6: 293-303.

Cusset C. 1983. Contribution à l'étude des Podostemaceae. 7. Ledermanniella Engl. Sous-genre Phyllosoma C.Cusset. Bulletin du Museum National d'Histoire Naturelle, Paris, 4e sér. 5, sect. B, Adansonia 4: 361-390.

Cusset C. 1984. Contribution à l'étude des Podostemaceae. 8. Ledermanniella Engl. Sous-genre Ledermanniella. Bulletin du Museum National d'Histoire Naturelle, Paris, 4e sér, 6, sect. B, Adansonia 3: 249-278.

Cusset C. 1987. Podostemaceae. Flore du Cameroun 30. MESRES, Yaoundé, Cameroun.

Cusset C. 1997. Podostemaceae. Flora Zambeziaca 9, 2: 1-10.

Darbyshire I. (continuously updated). Tropical important plant areas. http:// science.kew.org/strategic-output/tropical-important-plant-areas.

Darbyshire I, Anderson, S, Asatryan A, et al. 2017. Important plant areas: revised selection criteria for a global approach to plant conservation. Biodiversity \& Conservation. doi: http://dx.doi.org/10.1007/s10531-017-1336-6.

Diop FN. 2010a. Ledermanniella abbayesii. The IUCN Red List of threatened species 2010: e.T185374A8398689. doi: http://dx.doi.org/10.2305/IUCN. UK.2010-3.RLTS.T185374A8398689.en. Downloaded on 22 Feb. 2017.

Diop FN. 2010b. Ledermanniella adamesii. The IUCN Red List of threatened species 2010: e.T185307A8386090. doi: http://dx.doi.org/10.2305/IUCN. UK.2010-3.RLTS.T185307A8386090.en. Downloaded on 22 Feb. 2017.

Diop FN. 2010c. Ledermanniella ledermannii. The IUCN Red List of threatened species 2010: e.T185295A8383832. doi: http://dx.doi.org/10.2305/ IUCN.UK.2010-3.RLTS.T185295A8383832.en. Downloaded on 22 Feb. 2017.

Engler A. 1909. Podostemonaceae africanae III. Botanische Jahrbucher 43: $378-381$

Engler A. 1915. Podostemonaceae. In: Pflanzenwelt Afrikas 3.1. Vegetation der Erde: 268-277. Engelmann, Leipzig.

Engler A. 1926. Podostemonaceae africanae. IV. Botanische Jahrbucher 60: $451-467$
Engler A. 1930. Podostemonaceae. In: Engler A, Prantl K (ed), Das Pflanzenfamilien. 2 Aufl. Band 18A: 1-68. Engelmann, Leipzig.

Fries RE. 1914. Botanische Untersuchungen, Band 1. Wissenschaftliche Ergebnisse der Schwedischen Rhodesia-Kongo-Expedition 1911-1912. Stockholm.

Ghogue J-P. 2010a. Ledermanniella annithomae. The IUCN Red List of threatened species 2010: e.T185360A8396116. doi: http://dx.doi. org/10.2305/IUCN.UK.2010-3.RLTS.T185360A8396116.en. Downloaded on 22 Feb. 2017

Ghogue J-P. 2010b. Ledermanniella bosii. The IUCN Red List of threatened species 2010: e.T185299A8384738. doi: http://dx.doi.org/10.2305/IUCN UK.2010-3.RLTS.T185299A8384738.en. Downloaded on 22 Feb. 2017.

Ghogue J-P. 2010c. Ledermanniella boumiensis. The IUCN Red List of threatened species 2010: e.T185271A8379387. doi: http://dx.doi. org/10.2305/IUCN.UK.2010-3.RLTS.T185271A8379387.en. Downloaded on 22 Feb. 2017.

Ghogue J-P. 2010d. Ledermanniella cristata. The IUCN Red List of threatened species 2010: e.T185309A8386232. doi: http://dx.doi.org/10.2305/ IUCN.UK.2010-3.RLTS.T185309A8386232.en. Downloaded on 22 Feb. 2017.

Ghogue J-P. 2010e. Ledermanniella kamerunensis. The IUCN Red List of threatened species 2010: e.T185482A8420187. doi: http://dx.doi. org/10.2305/IUCN.UK.2010-3.RLTS.T185482A8420187.en. Downloaded on 22 Feb. 2017.

Ghogue J-P. 2011. The status and distribution of freshwater plants of central Africa. In: Brooks EGE, Allen DJ, Darwall WRT (compilers), The status and distribution of freshwater biodiversity in central Africa: 92-109. IUCN, Gland, Switzerland and Cambridge, UK.

Gilg E. 1901. Sphaerothylax warmingiana. Kongelige Danske Videnskabernes Selskabs Skrifter. Naturvidenskabelige og Mathematiske Afdeling VI. XI. I: 17-24.

Hall JB. 1971. New Podostemaceae from Ghana with notes on related species. Kew Bulletin 26, 1: 125-136.

Hauman L. 1944. Deux Podostemonacées Nouvelles du Congo-Belge. Bulletin du Jardin Botanique de l'État à Bruxelles 17: 179-180.

Hauman L. 1948. Podostemaceae. Flore du Congo Belge et du RuandaUrundi Vol. 1: 219-226.

Hess H. 1953. Über die Familien der Podostemonaceae und Hydrostachyaceae in Angola. Berichte der Schweizerischen Botanischen Gesellschaft 63: $360-383$.

IPNI (continuously updated). The International Plant Names Index. http:// ipni.org/.

IUCN. 2012. IUCN Red List categories and criteria: Version 3.1. Second edition. Gland, Switzerland and Cambridge, UK.

Katayama N, Koi S, Kato M. 2010. Expression of SHOOT MERISTEMLESS, WUSCHEL, and ASYMMETRIC LEAVES1 Homologs in the shoots of Podostemaceae: Implications for the evolution of novel shoot organogenesis. The Plant Cell 22, 7: 2131-2140. doi: http://dx.doi.org/10.1105/ tpc.109.073189.

Kato M. 2016. Multidisciplinary studies of the diversity and evolution in riverweeds. Journal of Plant Research 129: 397-410.

Kita Y, Koi S, Rutishauser R, et al. 2008. A new species of Ledermanniella (Podostemaceae) from Cameroon. Acta Phytotaxonomica et Geobotanica 59, 3: 223-227.

Koi S, Kita Y, Hirayama Y, et al. 2012. Molecular phylogenetic analysis of Podostemaceae: implications for taxonomy of major groups. Botanical Journal of the Linnean Society 169: 461-492.

Ledermann C. 1912. Eine botanische Wanderung nach Deutsch-Adamaua, Mitteilungen aus den deutschen Schutzgebieten 1: 20-55, map 3.

Léonard J. 1993. Etude phytosociologique des chutes de la Tshopo (Kisangani-Zaire). Bulletin Jardin Botanique Nationale Belgique 62: 283-347.

Lobreau-Callen D, LeThomas A, Suarez-Cervera M. 1998. Ultrastructural characters of the pollen of some Podostemales. Affinities with advanced Rosidae (in French). Compte Rendu Académie des Sciences de la vie, Paris III, 321: 335-345.

McNeill J, Barrie FR, Buck WR, et al. (eds). 2012. International Code of Nomenclature for algae, fungi, and plants (Melbourne Code). Adopted by the Eighteenth International Botanical Congress Melbourne, Australia, July 2011 (electronic ed.). Bratislava, International Association for Plant Taxonomy.

Moline P, Thiv M, Ameka GK, et al. 2007. Comparative morphology and molecular systematics of African Podostemaceae-Podostemoideae, with emphasis on Dicraeanthus and Ledermanniella from Cameroon. International Journal Plant Science 168, 2: 159-180.

Nyakabwa M. 1982. Phytocénoses de l'écosystème urbain de Kisangani. Thèse Doctorale Faculté de Sciences, Université Kisangani 3 parties: 1-998. 
Obermeyer AA. 1970. Podostemaceae. In: Codd LE, De Winter B, Rycroft HB (eds), Flora of Southern Africa 13: 205-211. Department of Technical Services, RSA.

Onana J-M, Cheek M. 2011. Red data book of the flowering plants of Cameroon: IUCN Global Assessments. Royal Botanic Gardens, Kew.

Philbrick CT, Novelo NR. 1995. New World Podostemaceae: Ecological and evolutionary enigmas. Brittonia 47, 2: 210-222.

Rial A. 2002. Une nouvelle espèce de Macropodiella (Podostemaceae) de Guinée Équatoriale. Adansonia 24, 2: 295-297.

Rutishauser R, Pfeifer E, Bernard A. 2004. Podostemaceae of Africa and Madagascar: keys to genera and species, including genera description, illustrations to all species known, synonyms, and literature cited. www. systbot.uzh.ch/static/podostemaceae/keys/podostemaceae_key.pdf.

Schenk JJ, Herschlag R, Thomas DW. 2015. Describing a new species into a polyphyletic genus: taxonomic novelty in Ledermanniella s.I. (Podostemaceae) from Cameroon. Systematic Botany 40, 2: 539-552. doi: http:// dx.doi.org/10.1600/036364415x688330.

Schenk JJ, Thomas DW. 2004. A new species of Ledermanniella (Podostemaceae) from Cameroon. Novon 14, 2: 227-232.

Sieben E. 2010. Ledermanniella warmingiana. The IUCN Red List of threatened species 2010: e.T185590A8442507. doi: http://dx.doi.org/10.2305/ IUCN.UK.2010-3.RLTS.T185590A8442507.en. Downloaded on 22 Feb. 2017.
Taylor G. 1953. Notes on the Podostemaceae for the revision of the Flora of West Tropical Africa. Bulletin British Museum (Natural History) 1, 3: 51-79. Taylor G. 1954. Podostemaceae. In: Keay RWJ (ed), Flora of West Tropical Africa 1, 1: 122-127. Crown Agents, London.

Thiers B. (continuously updated). Index Herbariorum: A global directory of public herbaria and associated staff. New York Botanical Garden's Virtual Herbarium. http://sweetgum.nybg.org/ih/.

Thiv M, Ghogue J-P, Grob V, et al. 2009. How to get off the mismatch at the generic rank in African Podostemaceae? Plant Systematics and Evolution 283: 57-77. doi: http://dx.doi.org/10.1007/s00606-009-0214-4.

Timberlake J, Dowsett-Lemaire F, Bayliss J, et al. 2009. Mt Namuli, Mozambique: biodiversity and conservation: 114. www.kew.org/sites/default/files/ kppcont_046094.pdf.

Wang P, Dong S, Lassoie JP. 2013. The large dam dilemma: an exploration of the impacts of hydro projects on people and the environment in China. Springer.

Warming E, Gilg E. 1903. Podostemonaceae. In: Baum, Kunene-Sambesi Expedition: 240-241. Verlag des Kolonial-Wirtschaftlichen Komitees, Berlin. White F. 1983. The vegetation of Africa. UNESCO, Paris.

Wright CH. 1909. Dicraea tenax. In: Thistleton-Dyer WT (ed), Flora of Tropical Africa VI-section 1: 125-126. Reeve, London. 